NBER WORKING PAPER SERIES

\title{
THE ECONOMIC IMPLICATIONS OF CORPORATE FINANCIAL REPORTING
}

\author{
John R. Graham \\ Campbell R. Harvey \\ Shiva Rajgopal \\ Working Paper 10550 \\ http://www.nber.org/papers/w10550 \\ NATIONAL BUREAU OF ECONOMIC RESEARCH \\ 1050 Massachusetts Avenue \\ Cambridge, MA 02138 \\ June 2004
}

We thank the following people for suggestions about survey and interview design: Sid Balachandran, Phil Berger, Robert Bowen, Shuping Chen, Hemang Desai, Julie Edell, Gavan Fitzsimons, Michelle Hanlon, Frank Hodge, Jim Jiambalvo, Bruce Johnson, Jane Kennedy, Lisa Koonce, SP Kothari, Mark Leary, Baruch Lev, Bob Libby, John Lynch, John Martin, Dawn Matsumoto, Ed Maydew, Jeff Mitchell, Mort Pincus, Jim Porteba, Brian Turner, Terry Shevlin, Doug Skinner, K.R. Subramanyam, and especially Mark Nelson. We have also benefited from useful discussions with Michael Jensen. A special thanks to Chris Allen, Cheryl de Mesa Graziano, Dave Ikenberry, Jim Jiambalvo and Jennifer Koski, who helped us administer the survey and arrange some interviews. Mark Leary provided excellent research support, Andrew Frankel provided editorial assistance, and Tara Bowens and Anne Higgs provided data entry support. We thank Gary Previts, Josh Ronen, Shiva Shivakumar and seminar participants at Case Western University, Duke University, National Forum on Corporate Finance and the University of Washington for comments. Finally, we thank the financial executives who generously allowed us to interview them or who took time to fill out the survey. We acknowledge financial support from the John W. Hartman Center at Duke University and the University of Washington. Please address correspondence to John Graham (john.graham@duke.edu), Campbell Harvey (cam.harvey@duke.edu), or Shiva Rajgopal (rajgopal@u.washington.edu). The views expressed herein are those of the author(s) and not necessarily those of the National Bureau of Economic Research.

(C2004 by John R. Graham, Campbell R. Harvey, and Shiva Rajgopal. All rights reserved. Short sections of text, not to exceed two paragraphs, may be quoted without explicit permission provided that full credit, including (C) notice, is given to the source. 
The Economic Implications of Corporate Financial Reporting

John R. Graham, Campbell R. Harvey, and Shiva Rajgopal

NBER Working Paper No. 10550

June 2004

JEL No. G35, G32, G34

\section{ABSTRACT}

We survey 401 financial executives, and conduct in-depth interviews with an additional 20, to determine the key factors that drive decisions related to reported earnings and voluntary disclosure. The majority of firms view earnings, especially EPS, as the key metric for outsiders, even more so than cash flows. Because of the severe market reaction to missing an earnings target, we find that firms are willing to sacrifice economic value in order to meet a short-run earnings target. The preference for smooth earnings is so strong that $78 \%$ of the surveyed executives would give up economic value in exchange for smooth earnings. We find that $55 \%$ of managers would avoid initiating a very positive NPV project if it meant falling short of the current quarter's consensus earnings. Missing an earnings target or reporting volatile earnings is thought to reduce the predictability of earnings, which in turn reduces stock price because investors and analysts hate uncertainty. We also find that managers make voluntary disclosures to reduce information risk associated with their stock but try to avoid setting a disclosure precedent that will be difficult to maintain. In general, management's views provide support for stock price motivations for earnings management and voluntary disclosure, but provide only modest evidence in support of other theories of these phenomena (such as debt, political cost and bonus plan based hypotheses).

$\begin{array}{ll}\text { John R. Graham } & \text { Campbell R. Harvey } \\ \text { Department of Economics } & \text { Department of Economics } \\ \text { Duke University } & \text { Duke University } \\ \text { Durham, NC 27708 } & \text { Durham, NC 27708 } \\ \text { jgraham@mail.duke.edu } & \text { and NBER } \\ & \text { cam.harvey@duke.edu }\end{array}$

Shiva Rajgopal

Department of Economics University of Washington Seattle, WA 98195 rajgopal@u.washington.edu 


\section{The Economic Implications of Corporate Financial Reporting}

\section{Introduction}

We conduct a comprehensive survey that asks CFOs to describe their choices related to reported accounting numbers and voluntary disclosures. Our objective is to address the following questions: Do managers care about earnings benchmarks or earnings trends and, if yes, which benchmarks are perceived to be relatively more important? What factors motivate firms to exercise discretion, and even sacrifice economic value, to manage reported earnings numbers? What is the relative importance of various theories proposed by academic research to explain earnings management and voluntary disclosure? Triangulating our results with those from archival empirical research enhances our understanding of these issues.

We investigate these questions using a combination of field interviews and a survey instrument. By using these methods, we are able to address issues that traditional empirical work based on large archival data sources cannot. A combination of surveys and field interviews enables us to (i) get financial officers to rank-order the relative importance of extant academic theories to explain financial reporting policies; (ii) discover new patterns of behavior and new explanations for known patterns; and (iii) highlight stylized facts on issues such as earnings benchmarks, earnings guidance, and the marginal investor that are relatively hard to document from archival data. Overall, our evidence provides a reference point describing where academic research and real-world financial reporting policies are consistent and where they appear to differ.

Our results indicate that CFOs consider earnings, not cash flows, to be the key metric considered by outsiders. The two key earnings benchmarks are quarterly earnings for the same quarter last year and the analyst consensus estimate. Meeting or exceeding benchmarks is very important. Managers describe a trade-off between the short-term need to "deliver earnings" and the long-term objective of making valuemaximizing investment decisions. Executives believe that hitting earnings benchmarks builds credibility with the market and helps to maintain or increase their firm's stock price.

The severe stock market reactions to small EPS misses can be explained as evidence that the market believes that most firms can "find the money” to hit earnings targets. Not being able to find one or two cents to hit the target might be interpreted as evidence of hidden problems at the firm. Additionally, if the firm had guided analysts to the EPS target, then missing the target can indicate that a firm is managed poorly in the sense that it can not accurately predict its own future. Both of these scenarios breed uncertainty about a firm's future prospects, which in turn affects its stock price. While managers are willing to make small or moderate sacrifices in economic value to meet the earnings expectations of 
analysts and investors (to avoid the severe market reaction for under-delivering), they are hesitant to employ accounting adjustments to hit earnings targets, perhaps as a consequence of the stigma attached to accounting fraud in the post-Enron environment.

An overwhelming majority of CFOs prefer smooth earnings (versus volatile earnings). Volatile earnings are thought to be riskier than smooth earnings. Moreover, smooth earnings ease the analyst's task of predicting future earnings. Predictability of earnings seems to be the over-arching concern among CFOs. Less predictable earnings -- either a missed earnings target or volatile earnings - command a risk premium in the market. A surprising $78 \%$ of the surveyed executives would give up economic value in exchange for smooth earnings.

Most executives feel they are making an appropriate choice when sacrificing value to smooth earnings or to hit a target. The turmoil that can result in equity and debt markets from a negative earnings surprise can lead to costs (at least in the short-run). Therefore, many executives feel that they are choosing the lesser evil by sacrificing long-run value to avoid short-term turmoil (which can itself lead to value loss). In other words, if a decision is made to sacrifice value, many executives feel that it is in some sense forced on them by the market's severe (over) reaction to earnings misses. Many argue that the system (that is, financial market pressures and overreactions) encourages decisions that at times sacrifice value to meet earnings targets.

Companies voluntarily disclose information to facilitate "clarity and understanding” to investors. Lack of clarity, or a reputation for not consistently providing precise and accurate information, can lead to under-pricing of the firm's stock. In short, disclosing reliable and precise information can reduce “information risk” about a company's stock, which in turn reduces the required return. Concerns about revealing sensitive information to competitors and worries about starting disclosure precedents that are difficult to maintain (such as manager-provided earnings forecasts) appear to constrain voluntary disclosure. Managers prefer in some cases to release bad news earlier than good news in order to build credibility with the capital market and avoid potential lawsuits.

When benchmarked against the extant academic literature, our evidence offers four key insights. First, accounting earnings matter more to managers than cash flows for financial reporting purposes, which contrasts with the emphasis on cash flows pervasive in the finance literature. Second, managers are interested in meeting or beating earnings benchmarks primarily to influence stock prices, and less so in response to incentives related to debt covenants, credit ratings, political visibility and employee bonuses that have traditionally been the focus of academic work (e.g., Watts and Zimmerman 1978, 1990). Third, holding cash flows constant, managers care a lot about smooth earnings paths, although this concern has been somewhat under-emphasized in the academic literature (see Ronen and Sadan 1981 for an earlier 
reference on smoothing). Finally, managers are willing to sacrifice economic value to manage financial reporting perceptions. It is difficult for archival empirical research to convincingly document such behavior.

Our work is related to, but in important ways differs from and adds to, three papers. Nelson, Elliot and Tarpley $(2002,2003)$ survey the auditors from one audit firm to learn about company attempts to manage earnings that were detected by the auditors. Hodge (2003) seeks to assess the earnings quality perceptions of small investors. The key difference between our work and prior research is that we find direct evidence of managers' willingness to give up real economic value to manage financial reporting perceptions. ${ }^{1}$ Our research differs from prior work in four other ways. First, rather than rely on third-party perceptions of what motivates CFOs' financial-reporting decisions, we survey and interview the decisionmakers directly. A potential disadvantage of our approach is that executives may be unwilling to admit to bad behavior. However, given that executives are willing to admit to sacrificing value in order to achieve reporting objectives, admitting bad behavior does not appear to be a major problem in our study. Moreover, directly asking the executives has the advantage that they presumably have the best information about the circumstances surrounding their decisions. ${ }^{2}$ Second, the scope of our survey is broader, in that we cover both earnings management decisions and voluntary disclosure practices. Third, we sample a large cross-section of firms. Fourth, we analyze survey responses conditional on firm characteristics. We examine the relation between the executives' response and firm size, P/E ratio, leverage, credit rating, managerial ownership, industry, CEO age, and the education of the CEO. By examining such conditional responses, we attempt to shed light on the implications of various disclosure and earnings management theories related to firm heterogeneity in size, risk, investment opportunities, informational asymmetry, analyst coverage, level of guidance, and management incentives.

The paper is organized as follows. The second section details the methodology and design of the survey. The importance of reported earnings and actions taken to manage earnings are discussed in the third and the fourth sections, respectively. The fifth section deals with managers' desire for smooth earnings. The sixth section presents results on voluntary disclosure decisions. The seventh section highlights observations from interviews, and the last section offers some concluding remarks.

\footnotetext{
${ }^{1}$ Nelson et al. (2002) find that auditors identify a modest number of earnings management attempts as "structured transactions" with real costs (e.g., transaction costs), especially among the 38 leasing transactions and the consolidations of equity/cost method that they identify. In contrast, our results indicate that sacrificing value to achieve earnings targets is much more pervasive than identified by auditors.

${ }^{2}$ Further, unlike archival work where executive decisions are filtered by the subsequent decisions and perceptions of auditors and others in the financial reporting process, we observe the decision process without such filtering.
} 


\section{Method}

\subsection{Surveys versus archival research}

The typical large-sample archival analysis provides statistical power and cross-sectional variation. However, these studies can suffer from several weaknesses related to variable specification and the inability to ask qualitative questions. First, large sample analyses cannot always speak to the relative importance of competing hypotheses for a phenomenon because the explanatory variable with the least measurement error will often dominate in a regression analysis. Second, developing good empirical proxies for voluntary disclosure, and especially earnings management, is non-trivial. Third, in some cases, large-sample studies cannot assess which theory best fits the data because specific variables potentially proxy for multiple theories. For example, size might explain cross-sectional variation in earnings management or disclosure because of political costs, the information environment, or firm risk. In contrast, surveys and interviews offer an opportunity to ask CFOs very specific and qualitative questions about the motivation behind financial reporting choices. Moreover, the survey and interview format enables us to adopt an integrated perspective on the trade-offs between multiple goals underlying earnings management and disclosure (as recommended by Fields, Lys, and Vincent (2001)), rather than focus on one narrow explanation for these phenomena. Surveys can also suggest new explanations that have not been previously examined by academic researchers.

The survey methodology suffers from several potential limitations as well. Surveys measure beliefs, which may not always coincide with actions. Moreover, executives can potentially parrot explanations that they learned in business school (because they think this is what we want to hear), rather than state their true beliefs. It is also possible that executives make (close to) optimal decisions, even if they do not articulate their explanation in academic terms when describing the decision-making process. Perhaps some of the survey questions are misunderstood. It is also possible that the respondents are not representative of the underlying population. Even with these considerations, we hope to provide unique information about how firms make financial reporting decisions. We hope that researchers will use our results to develop new theories or potentially modify or abandon existing views. We also hope that practitioners and students benefit from our analysis by noting how other firms operate and also where practice diverges from academic recommendations.

\subsection{Survey design and delivery}

Our main survey focuses on two broad areas: voluntary disclosure choices and earnings management. Based on a review of the existing literature, we developed a draft survey. The draft version 
of the survey contained 10 questions, most with subsections. One question collected demographic information about the sample firms. We solicited feedback from several academic researchers and CFOs on the survey content and design. We also distributed drafts to marketing research experts on survey design and execution. Our goal was to minimize biases induced by the questionnaire and maximize the response rate. We used the penultimate version of the survey to conduct beta tests to seek feedback and to make sure that the time required to complete the survey was reasonable. Our beta testers took 10-15 minutes to complete the survey. Based on this and other feedback, we made changes to the wording of some questions and added two more questions. The final survey contained 12 questions, most with subsections, and the paper version was 5 pages long. The survey is posted on the Internet at http://faculty.fuqua.duke.edu/ jgraham/finrep/survey.htm

We use two different versions of the survey, with the ordering scrambled on the non-demographic questions. We were concerned that the respondents might (i) abandon the survey as they filled out questions that had many subparts; and/or (ii) be unduly influenced by the order of the questions. If the first concern were valid, we would expect to see a higher proportion of respondents answering the subparts that appear at the beginning of any given question. If the second concern was valid, we would expect the answers to differ depending on the version of the survey. However, we find no evidence that the response rate or quality of responses depends on the ordering of the questions.

We used two mechanisms to deliver the survey. First, we e-mailed the survey to 3,174 members of an organization of financial executives that work for public companies and have the job title of CFO, Chief Accounting Officer, Treasurer, Assistant Treasurer, Controller, Assistant Controller, or Vice President (VP), Senior VP or Executive VP of Finance. As a secondary effort, we contacted executives from CFO forums at the University of Illinois and the University of Washington. ${ }^{3}$ Two hundred sixty seven members responded to the Internet survey, for a response rate of approximately 8.4 percent. In the remainder of the paper, for simplicity, we refer to the survey respondents as CFOs. Note also that an overwhelming majority of interviews hold the CFO title.

Second, a paper version of the survey was administered at a conference on current financial reporting issues conducted by an organization of financial executives on November 17 and 18, 2003 in New York City. This conference was attended by a wide variety of public companies. Before the keynote address, the executives were asked to fill out the paper version of the survey that was placed on their chairs. We used this approach in an attempt to obtain a large response rate, and in fact approximately onefifth of the conference attendees, or 134 participants, filled out the survey - these respondents make up approximately one-third of our final sample.

\footnotetext{
${ }^{3}$ We thank Dave Ikenberry and Jennifer Koski for coordinating the administration of the survey to the National Forum on Corporate Finance (NFCF) and the University of Washington CFO Forum, respectively.
} 
Averaged across the two ways in which the survey was administered, our response rate of $10.4 \%$ falls within the ranges of response rates reported by several recent surveys of financial executives. For example, Trahan and Gitman (1995) report a response rate of $12 \%$ in a survey mailed to 700 CFOs, while Graham and Harvey (2001) obtain a 9\% response rate for 4,400 faxed surveys. Brav, Graham, Harvey and Michaely (2004) have a 16\% response rate. Of the total 405 responses, four sets of two were responses from the same firm, so we averaged each pair into a single observation (leaving 401 unique firm responses). We delete seven incomplete responses, to permit full comparability across all questions. Finally, 46 of the responses are from private firms and 36 do not indicate whether they are public or private. Other than when we directly compare public firms to the 46 private firms, the analysis below is based on the 312 responses that we can classify as public firms.

\subsection{Interview design and delivery}

In addition to the survey, we separately conducted 20 one-on-one interviews with senior executives (typically the CFO or Treasurer). To identify interview subjects, we chose firms in different industries and with different analyst coverage and market capitalization. These firms are not randomly picked because we purposefully wanted some cross-sectional variation in their financial reporting policies. Six of the 20 interviews were conducted in person and the rest were done via telephone. The interviews were arranged with the understanding that the identity of the firms and executives will remain anonymous.

We conduct interviews according to the best practices described in Sudman and Bradburn (1983). At the beginning of each interview, we ask the executive to describe their policy related to voluntary disclosures, the importance of earnings-related benchmarks, and the ways to achieve such benchmarks within the purview of GAAP. "Riskier” questions are asked later in the interview. We attempt to conduct the interview so as not to ask leading questions or influence the answers or the initial direction of the interviews with a pre-set agenda. Rather, we let the executive tell us what is important at his or her firm about voluntary disclosures and earnings targets, and then we follow up with clarifying questions. Many of the clarifying questions are similar to those that appear on the survey. Whenever possible, we numerically code the interviews (Flanagan 1954). This helps us link the two sources of information.

The interviews varied in length, lasting from 40 to 90 minutes. The executives were remarkably candid in their discussions. We integrate the interviews with the survey results to reinforce or clarify the survey responses. In general, the interviews provide insight and depth to further our understanding about the content of the survey responses. 


\subsection{Summary statistics and data issues}

Table 1, panel A presents summary information about the firms in our sample. The statistics are based on the non-missing values for each particular characteristic. Note that the companies range from small (15.1\% of the sample firms have sales of less than $\$ 100$ million) to very large (25.6\% have sales of at least $\$ 5$ billion). Furthermore, $7.8 \%$ of the firms do not have any analyst coverage, while $16.7 \%$ are covered by at least 16 analysts. We also collect information about CEOs (implicitly assuming that the executives that we survey act as agents for the CEOs). Table 1, panel B presents Pearson correlations among the demographic variables. One interesting relation is that the number of analysts covering a firm is higher for firms that provide more earnings guidance ( $\rho=0.437)$.

The notes to Table 2 describe the "breakpoints" that we use to categorize firms, based on firm characteristics (small vs. large, high P/E vs. low P/E). For example, in subsequent analyses, we refer to firms with revenues greater than $\$ 1$ billion as "large" and firms with a P/E ratio greater than 17 (the median for our sample) as "high P/E firms." Overall, the substantial variation in firm and executive characteristics permits a rich description of financial reporting practices and allows us to infer which corporate actions are consistent with academic theories.

Table 1, panels C and D compare summary information about the firms we survey and interview to Compustat information for the following variables: sales, debt-to-assets, dividend yield, earnings per share, credit rating, book to market, and price-earnings ratios. For each variable, in each panel, we report the sample average and median, and compare these values to those for the universe of Compustat firms as of November 2003 (the month we conducted most of the survey). The table reports the percentage of sample firms that fall into each quintile (based on separate Compustat quintile breakpoints for each variable). The reported percentages can then be compared to the benchmark 20 percent, which allows us to infer whether our samples are representative of Compustat firms, and if so, on which dimensions.

Relative to the typical Compustat firm, the survey firms are larger, more levered, and have higher dividend yields. When book-to-market is considered, the survey firms are representative of the average Compustat firm. We have fewer firms that report negative earnings compared to the typical Compustat firm, as evidenced by very few survey observations in lower price-earnings quintiles. However, when we delete firms that report negative earnings from the sample, the price-earnings ratios of the survey firms are closer to the distribution as per Compustat. 


\section{The Importance of Reported Earnings}

\subsection{EPS focus}

Table 2, row 1 of panel A reveals that earnings is the favorite financial metric of outsiders, as perceived by CFOs. One hundred fifty nine of the respondents rank earnings as the number one metric, relative to 36 top ranks each for revenues and cash flows from operations (Figure 1). This finding is noteworthy because cash flows continue to be the measure of firm-value emphasized in the academic finance literature. Revenue also appears to substantially lag earnings in terms of perceived importance by CFOs.

The conditional analyses, reported in panel B, reveal several interesting insights about the importance of earnings. For distressed firms, especially those reporting negative earnings, we would expect cash flows from operations and other liquidity measures to assume more importance than earnings. Consistent with this conjecture, unprofitable and younger firms rank earnings as relatively less important (see panel $B$, row 1). However, apart from pro-forma earnings, there appears to be no distinct pattern in the importance of other measures for unprofitable firms in the data. For firms where translation of economic events into earnings is slow, leading indicators such as patents or product pipeline might be viewed as being more important than earnings. However, there does not appear to be any differential importance in earnings for technology firms, where leading indicators are likely to be more important, relative to other industries (panel B, row 1). One interviewed CFO notes that leading indicators are important only because they feed into future earnings.

Regarding the other metrics, the conditional analyses reveal that cash flows appear relatively more important in younger firms and firms where less guidance is given (panel B, row 3). It is also interesting to note that private firms place more emphasis on cash flow from operations than public firms (panel B, row 3), suggesting, perhaps, that capital market motivations drive the focus on earnings. ${ }^{4}$ Revenues rank higher among firms that report higher sales growth (panel B, row 2). Unprofitable firms, firms with young CEOs, and firms where guidance and analyst coverage are high emphasize pro-forma earnings (panel B, row 5). These patterns are consistent with firms responding to capital market pressures to use pro-forma earnings to make their unprofitable GAAP earnings look more profitable.

The interviewed CFOs indicate that the GAAP earnings number, especially EPS, is the key metric upon which the market focuses ("earnings are in a class by themselves"). One interviewee observes that this "near-obsession with earnings is a phenomenon that started in the late 80s and climaxed during the Internet boom.” Four reasons stand out as causing this focus on EPS. First, the world is complex and the

\footnotetext{
${ }^{4}$ Recall that all numbers in all columns of the tables are for public firms, except for the column labeled private firms.
} 
number of available financial metrics is enormous. Investors need a simple metric that summarizes corporate performance, that is easy to understand, and is relatively comparable across companies. EPS satisfies these criteria. Second, the EPS metric gets the broadest distribution and coverage by the media. Third, by focusing on one number, the analyst's task of predicting future value is made somewhat easier. The analyst assimilates all the available information and summarizes it in one number: EPS. Four, analysts evaluate a firm's progress based on whether a company hits the consensus EPS number. Investment banks can also assess analysts’ performance by evaluating how closely they predict the firm's reported EPS. ${ }^{5}$

\subsection{Earnings benchmarks}

Several performance benchmarks have been proposed in the literature (e.g., Burgustahler and Dichev 1997 and Degeorge, Patel, Zeckhauser 1999), such as previous years' or seasonally lagged quarterly earnings, loss avoidance, or analysts' consensus estimates. The survey evidence reported in Table 3 indicates that, while all four metrics are important, the rank ordering among them is as follows: (i) same quarter last year (84.3\% agree); (ii) analyst consensus estimate (68.8\% agree); (iii) reporting a profit (65\% agree); and (iv) previous quarter EPS (54.6\% agree) (see Figure 2). Degeorge et al. (1999) find a somewhat different rank ordering in their archival data: (i) reporting a profit; (ii) earnings same quarter last year; and (iii) analysts consensus estimates. Degeorge et al. (1999) do not investigate previous quarter earnings.

Conditional analyses reported in panel B reveal several interesting insights. Profitable firms rank same quarter last year EPS and analyst consensus forecast as more important than unprofitable firms (panel B, rows 1 and 3). Firms that are large, report high sales growth, have greater analyst coverage and provide greater earnings guidance regard analyst consensus forecasts as more important than firms with smaller size, slower growth, less analyst coverage and less earnings guidance (panel B, row 3). It is interesting to note that meeting seasonally lagged earnings and reporting a profit are perceived as unconditionally important earnings benchmarks (that is, there is not much cross-sectional variation on firm characteristics; see panel B, rows 1 and 2).

Before administering the survey, we expected the analyst consensus estimate to be the most important earnings benchmark. However, the responses indicate that same quarter last year's EPS seems to

\footnotetext{
${ }^{5}$ While there is agreement on the importance of the reported earnings number, interviewed CFOs acknowledge that the EPS number contains many discretionary components and is relatively susceptible to manipulation. Some CFOs have tried to shift the attention of the analysts to "softer" data on value-drivers, such as new products introduced or the extent of innovation in the firm's business. CFOs believe that focus on value-drivers would encourage both firms and the market to adopt a longer-term perspective, instead of thinking about beating the quarterly benchmark.
} 
dominate the analyst consensus estimate. One reason for this result might be differential analyst coverage among our sample firms: In firms that have substantial analyst coverage, or that provide substantial guidance, the consensus earnings number is approximately as important as the four quarters lagged number. Given that these firms are large and are frequently covered in the press, this might have affected our prior beliefs. The survey reveals that the importance of the consensus earnings number is conditional on the degree of analyst coverage, guidance, and size.

Interviewed CFOs point out that in press reports about a firm's earnings, the first item is often a comparison of current quarter's earnings with four quarters lagged quarterly earnings. The next item mentioned is often the analyst consensus estimate for the quarter. Interviewed CFOs also mention that while the analyst forecast can be guided by management, last year's quarterly earnings number is a benchmark that is harder, if not impossible, to manage after the 10-Q SEC filing has been made. Finally, several executives mention that comparison to seasonally lagged earnings numbers provides a measure of earnings momentum and growth, and therefore is a useful gauge of corporate performance.

\subsection{Why meet earnings benchmarks?}

The academic accounting literature, summarized by Healy and Wahlen (1999), Dechow and Skinner (2000) and Fields, Lys and Vincent (2001), provides several motivations for why managers might exercise accounting discretion to achieve some desirable earnings goal (such as hitting an earnings target): employee bonuses, bond covenants, stakeholder motivations, and stock price motivations. We evaluate the evidence for each of these motivations in turn and also propose a new hypothesis based on survey evidence (career concerns). ${ }^{6}$ The data are presented in Table 4.

\subsubsection{Stock price driven motivation}

Research suggests that the market cares about earnings benchmarks. Barth, Elliot and Finn (1999) find that, all else constant, firms that report continuous growth in annual earnings are priced at a premium relative to other firms. Skinner and Sloan (2002) show that growth firms that fail to meet earnings benchmarks (such as analyst expectations) suffer large negative price reactions on the earnings announcement date. Bartov, Givoly and Hayn (2002) find that firms that meet or beat analyst expectations often report superior future accounting performance. The survey evidence is strongly consistent with the

\footnotetext{
${ }^{6}$ We did not ask specific survey questions related to the taxes and regulation motivations for meeting benchmarks, although literature surveys (e.g., Healy and Wahlen 1999, Fields et al. 2001 and Shevlin and Shackelford 2001) identify these motivations as well. For one thing, incentives to meet earnings benchmarks to exploit regulatory requirements are specific to certain industries, such as banking and insurance, and incorporating such industryspecific questions in a broad survey like ours is difficult. Furthermore, our CFO interviews reveal that taxes are a relatively second-order incentive for meeting earnings benchmarks.
} 
importance of stock price motivations to meet or beat earnings benchmarks. An overwhelming 86.3\% of the survey participants believe that meeting benchmarks builds credibility with the capital market (Table 4, row 1). More than $80 \%$ agree that meeting benchmarks helps maintain or increase the firm's stock price (Table 4, row 2). Consistent with these results, managers believe that meeting benchmarks conveys future growth prospects to investors (Table 4, row 4). In sum, the dominant reason to meet or beat earnings benchmarks relates to stock prices.

\subsubsection{Stakeholder motivations}

Bowen, Ducharme and Shores (1995) and Burgstahler and Dichev (1997) state that by managing earnings firms are able to enhance their reputation with stakeholders, such as customers, suppliers and creditors, and hence get better terms of trade with these parties. A statistically significant majority of the respondents agree with the stakeholder story (Table 4, row 6). Conditional analyses show that the stakeholder motivation is especially important for firms that are small, in the technology industry, dominated by insiders, young, and not profitable (Table 4, row 6). Perhaps, suppliers and customers need more reassurances about the firm's future in such companies. An interviewed CFO, in an industry in which confidence of retail customers in the product market is a key consideration, said that the stakeholder hypothesis is likely to be a significant determinant of the accounting and disclosure decisions.

\subsubsection{Employee bonuses}

Several papers, beginning with Healy (1985), argue that managers exercise accounting discretion to maximize the present value of their bonus compensation (see Fields et al. 2001 for references). For example, Matsunaga and Park (2001) find that failure to meet analysts' consensus estimates results in pay cuts for the CEO. The survey evidence does not provide much support for the employee bonus motivation: There is no statistical difference between respondents who agree and disagree with this motivation (see row 8 of Table 4). Consistent with the survey evidence, interviewed CFOs view the compensation motivation as a second-order factor, at best, for exercising accounting discretion. They tell us that companies often have internal earnings targets (for the purpose of determining whether the executive earns a bonus) that exceed the external consensus target. ${ }^{7}$ Hence, meeting the external earnings target does not guarantee a bonus payout. Furthermore, several interviewed CFOs indicate that bonuses are a function of an internal "stretch goal," which exceeds the internal "budget EPS," which in turn

\footnotetext{
${ }^{7}$ The external targets are below the internal targets because the firms prefer that the external targets are not a stretch to attain, so the firm can avoid disappointing the market by missing the consensus.
} 
exceeds the analyst consensus estimates. Finally, many executives indicate that bonus payout is simply not that important relative to salary and stock compensation.

\subsubsection{Career concerns}

The interviews reveal that the desire to hit the earnings target appears to be driven less by shortrun compensation motivations than by career concerns. Most CFOs feel that their inability to hit the earnings target is seen by the executive labor market as a "managerial failure.” Repeatedly failing to meet earnings benchmarks can inhibit the upward or intra-industry mobility of the CFO or CEO, as the manager is seen either as an incompetent executive or a poor forecaster. According to one executive, "I miss the target; I'm out of a job.” Consistent with these implications, more than three-fourths of the survey respondents agree or strongly agree about the importance of management's external reputation in explaining a desire to hit the earnings benchmark (Table 4, row 3). We are not aware of a systematic exploration of such a career concern hypothesis in the literature on earnings management.

\subsubsection{Bond covenants}

Some research proposes that earnings might be managed to reduce the probability of violating a covenant, and hence the expected cost of debt (Watts and Zimmerman 1990). For example, Burgstahler (1997) suggests that loss avoidance reduces the cost of debt. The survey evidence does not support the bond covenant hypothesis for meeting earnings benchmarks (Table 4, row 9). This finding is consistent with what we find in our interviews, as well as with comments in the Dechow and Skinner (2000) review of the earnings management literature. While unconditional support for the bond covenant motivation is low, we find that firms that are perhaps closer to violating covenants (highly leveraged, unprofitable) consider bond covenants to be relatively more important (Table 4, row 9). Finally, private firms strongly support the covenant hypothesis.

\subsection{Consequences of failure to meet earnings benchmarks}

To further understand the desire to meet earnings benchmarks, we explicitly ask about the consequences of failing to meet such benchmarks. Table 5 summarizes the results (see Figure 4). The top two consequences of a failure to meet earnings benchmarks are an increase in the uncertainty about future prospects (80.7\%) and a perception among outsiders that there are deeper previously unknown problems at the firm (60\%). The importance of these concerns increases with the degree of guidance.

To provide some context to these statistics, we turn to the interview evidence. Several CFOs argue that, "you have to start with the premise that every company manages earnings.” To be clear, these 
executives are not talking about violating GAAP or committing fraud. They are talking about "running the business" in a manner to produce smooth, attainable earnings every year (unless, of course, they are in a negative tailspin, in which case the firm goes into survival mode). ${ }^{8}$ This entails maneuvers with discretionary spending, changing the timing and perhaps the scale of investment projects, and turning some of the other dials discussed above. One CFO characterizes such decisions to meet earnings targets as the "screw-driver" effect: "you turn the screws just a little bit so that it fits." The common belief is that a well-run and stable firm should be able to "produce the dollars" necessary to hit the earnings target, even in a year that is otherwise somewhat down. Because the market expects firms to be able to hit or slightly exceed earnings targets, and in fact firms on average do just this (Brown and Caylor 2003), problems can arise when a firm does not deliver earnings. The market might assume that not delivering earnings means that there are potentially serious problems at the firm (because the firm apparently is so near the edge that it could not produce the dollars to hit earnings, and hence must have already used up its cushion). As one CFO put it, "if you see one cockroach, you immediately assume that there are hundreds inside the walls, even though you may have no proof that this is the case.” Corporations therefore have great incentive to avoid the "cockroach" of missing an earnings benchmark.

If management is unable to meet an earnings benchmark, then the market concludes that the firm probably has poorer future prospects and, hence, downgrades the firm stock price. However, CFOs point out that the market's reception is not as unfavorable if (i) you miss the quarterly consensus estimate but you can explain that the miss is driven by accounting accruals, not real cash flows (where "real" means, e.g., a drop in units sold); or (ii) you miss the quarterly consensus estimate but you can confirm guidance for the annual EPS number. Moreover, CFOs argue that the market is likely to tolerate an EPS miss if the non-financial leading indicators suggest good performance, thereby implying good future earnings. However, if non-financial leading indicators perform poorly as well, then the market is likely to punish the stock.

The other statistically significant factor motivating managers to avoid missing earnings benchmarks relates to the time spent in explaining, especially in conference calls to analysts, why the firm missed the target (Table 5, row 3). The interviewed CFOs say that if they meet the earnings target, they can devote more time in the conference call to the positive aspects of the firm's business and the firm's future prospects. Analysts and other stakeholders are more receptive to such discussions when the earnings target is met. In contrast, if the company fails to beat the guided number, then the tone of the conference call becomes substantially negative. The focus shifts completely to talking about why the company was unable to meet the consensus estimate. Analysts then doubt the credibility of every

\footnotetext{
${ }^{8}$ Parfet (2000), a CFO, makes a similar point in defense of earnings management.
} 
assumption underlying the current earnings number and the forecast of future earnings. Such a negative environment can cause the stock price to fall and even a debt-rating downgrade. In general, interviewed CFOs feel that the market hates unpleasant surprises, and surprised investors or analysts become defensive. Actions taken to meet or beat earnings benchmarks reduce the probability of such an unpleasant surprise. We turn to these actions in the following section.

\section{Actions Taken to Meet Earnings Benchmarks}

\subsection{Mix between accounting and real actions}

The literature has long recognized that managers can take accounting actions or real economic actions to meet earnings benchmarks. To learn more about the exact nature of the trade-offs between these two types of actions, we ask survey respondents to rank-order a list of accounting actions and real economic actions that managers can take to meet earnings targets. The results, reported in Table 6, are intriguing. There is strong evidence that managers take real economic actions to keep up accounting appearances (Figure 5). In particular, $80 \%$ of survey participants report that they would decrease discretionary spending on R\&D, advertising and maintenance (Table 6, row 1) to meet an earnings target. More than half (55.3\%) state that they would delay starting a new project to meet an earnings target, even when such a delay entails a small sacrifice in value (Table 6, row 2). This evidence is dramatic for two reasons. First, managers appear to be willing to burn "real" cash flows for the sake of reporting desired accounting numbers. As one executive put it, "there is a constant tension between the short-term and long-term" objectives of the firm. Second, getting managers to admit to such value decreasing actions in a survey suggests, perhaps, that our evidence represents only the lower bound of such behavior.

Real actions to manage earnings have not received as much attention in the literature relative to accounting attempts to manage earnings. A few papers (e.g., Dechow and Sloan 1991; Bartov 1993; Bushee 1998) present evidence of asset sales or $R \& D$ cuts to meet earnings targets. Roychowdhury (2003) argues that firms overproduce and give sales discounts to meet earnings targets. However, in attempts to document real earnings management using archival data, researchers can never be confident that real actions such as R\&D cuts are not driven by strategic considerations (such as a decrease in the firms' investment opportunity set). In contrast, our survey evidence does not suffer from such omitted variable concerns. ${ }^{9}$

\footnotetext{
${ }^{9}$ Our finding that firms sacrifice value to increase earnings is consistent with (i) Erickson, Hanlon and Maydew (2004), who find that firms pay extra taxes to boost reported earnings; and (ii) Bhojraj and Libby (2004), who find, in an experiment, that just before issuing stock, managers choose projects that they believe will maximize short-term earnings (and price) as opposed to total cash flows.
} 
The survey evidence does not offer much support for other real actions, such as selling investments or assets to recognize gains this quarter or repurchasing shares to boost EPS (Table 6, row 7 and 8). Thus, our findings differ from Bartov (1993) and Bens, Nagar, Skinner and Wong (2003), who argue that gains from asset sales and share repurchases, respectively, are used to manage earnings.

Another provocative finding from Table 6 is the relative absence of evidence that accounting actions are taken to meet earnings benchmarks. Survey respondents do not agree on the use of the following accrual-related maneuvers to manage earnings targets: drawing down on reserves previously set aside (Table 6, row 5), postponing an accounting charge (Table 6, row 6) or altering accounting assumptions in pension calculations (Table 6, row 9). This evidence is somewhat disconcerting, considering the large volume of literature devoted to documenting earnings management via accruals and discretionary accruals (Teoh, Welch and Wong 1998a, b; Sloan 1996; Nelson et al. 2002; and see Healy and Wahlen 1999, Dechow and Skinner 2000, Beneish (2001), and Fields et al. 2001 for surveys). Of course, the aftermath of accounting scandals at Enron and WorldCom and the certification requirements imposed by the Sarbanes-Oxley Act may have changed managers' preferences for the mix between accounting and real actions to manage earnings.

Our not finding evidence of accounting actions may indicate that managers are currently more likely to indulge in real as opposed to accounting based earnings management. One interviewed CFO points out that while auditors can second-guess the firm's accounting policies, they cannot readily challenge real economic actions that are taken in the ordinary course of business to meet earnings targets. Alternatively, managers may have hesitated to acknowledge the exercise of accounting discretion, even in an anonymous survey, in the post-Enron environment. An executive pointed out that CFOs at firms now go out of their way to assure stakeholders that there is no accounting based earnings management in their books. He goes on to observe that CFOs may have made the right accounting choice, out of the alternatives available to them under GAAP, at some time in the past, but they now run the risk that overzealous regulators will connect some dots ex post and make the case that an accounting treatment at a particular firm was driven by a need to manage earnings.

\subsection{Project adoption and earnings targets}

To gauge the degree to which managers are willing to alter investment decisions to meet earnings targets, we ask the following hypothetical question. 
Hypothetical scenario: Your company's cost of capital is $12 \%$. Near the end of the quarter, a new opportunity arises that offers a 16\% internal rate of return and the same risk as the firm. The analyst consensus EPS estimate is $\$ 1.90$. What is the probability that your company will pursue this project in each of the following scenarios?

\begin{tabular}{|c|c|c|c|c|c|c|c|}
\hline $\begin{array}{l}\text { Actual EPS if } \\
\text { you do not } \\
\text { pursue the }\end{array}$ & $\begin{array}{l}\text { Actual EPS if } \\
\text { you pursue the } \\
\text { project }\end{array}$ & \multicolumn{6}{|c|}{$\begin{array}{l}\text { The probability that the project will be } \\
\text { pursued in this scenario is ... } \\
\text { (check one box per row) }\end{array}$} \\
\hline & & $0 \%$ & $20 \%$ & $40 \%$ & $60 \%$ & $80 \%$ & $100 \%$ \\
\hline$\$ 2.00$ & $\$ 1.90$ & & & & & & \\
\hline$\$ 1.90$ & $\$ 1.80$ & & & & & & \\
\hline$\$ 1.80$ & $\$ 1.70$ & & & & & & \\
\hline$\$ 1.40$ & $\$ 1.30$ & & & & & & \\
\hline
\end{tabular}

Three facts about the question are worth noting: (i) the project has positive NPV because the internal rate of return exceeds the cost of capital by $4 \%$; (ii) undertaking the project in the first earnings scenario enables the firm to exactly meet the consensus estimate; (iii) under the second scenario, the firm misses the consensus estimate by undertaking the positive NPV project; and (iv) under the third and fourth scenarios, the company is not scheduled to meet the consensus estimate and adopting the project will take the firm further below the consensus.

The survey responses reported in Table 7 are fascinating (Figure 6). Although adopting the positive NPV project will not jeopardize the firm's chances of meeting the consensus estimate, the average probability of taking the project is $80 \%$. A priori, one might expect all survey respondents to take the project under the first scenario. One-fifth of the respondents would not take the earnings hit, perhaps because passing on the NPV positive project means they would beat rather than merely meet consensus. Alternatively, managers might hesitate to take the project-related earnings hit to hedge against the possibility that some unforeseen event before the end of the quarter may consume earnings. Interestingly, only $59 \%$ of the respondents would take the project in scenario two. Thus, $41 \%$ of the managers would not take a positive NPV project just to be able to meet the analyst consensus estimate! In scenario four, when EPS without taking the project at $\$ 1.40$ is a full 50 cents below consensus, about $52 \%$ of the managers would take the project and its associated 10 cent earnings hit. The fourth scenario result is surprising to us because we expected more managers to take a "big bath" and accept the project, given that they are not on track to hit consensus estimate anyway. Nonetheless, the above data strongly suggests that managers are willing to alter consumption and investment decisions to report certain earnings benchmarks. 
Conditional analyses, presented in panel B, reveal cross-sectional variation in the firm's probability of project adoption along only two major dimensions. Technology firms and firms that provide earnings guidance are more likely to avoid taking projects to meet earnings targets than non-technology firms and firms with less guidance. In additional conditional analysis (not reported in a table), we examine which firms say that they would deviate from weak monotonicity; that is, which firms become more likely to choose the project as they move down the four earnings scenarios. This analysis indicates that only $19 \%$ of the respondents say that they would violate monotonicity at all, and only $12 \%$ say would be more willing to undertake the project in scenario 4 than in scenario 3 . Large firms that give guidance and have a large number of analysts, as well as firms with CEOs that do not have MBAs, are most likely to violate monotonicity (i.e., have a probability of undertaking the project that increases as the expected earnings shortfall increases).

\subsection{Interview evidence}

In the interviews, many CFOs acknowledge that they face a trade-off between delivering (short-run) earnings and making long-run optimal decisions. The parameters of this trade-off are conditional on the firm's progress towards hitting consensus earnings. If the company is doing well, it is inclined to make long-run decisions that might reduce EPS (because they will make the benchmark EPS in any case). If the company has to stretch to attain their earnings target, they are more inclined to delay the start of a longrun project (or take some of the specific actions described below) because starting the project now would cause them to miss the earning target. Along these lines, several CFOs candidly acknowledge that they have made real economic sacrifices to hit an earnings target. One CFO indicates that several investment banks promote products whose sole objective is to create accounting income with zero or sometimes even negative cash flow consequences. Real actions often cited include: (i) postpone or eliminate hiring, R\&D, advertising, or even investments (to avoid depreciation charges to earnings or other start-up charges); (ii) manage other expenses by cutting the travel budget, delaying or canceling software spending, or deferring maintenance spending; (iii) sell bond investments that are not marked-to-market and, therefore, permit the firm to book gains; (iv) do asset securitizations; (v) manage the funding of pension plans; (vi) convince customers to increase their order quantity towards the end of the quarter; and (vii) announce an increase in product prices in the first quarter of the coming year to stimulate demand in the fourth quarter, or cut prices in the fourth quarter and hope to make that up in higher volume.

The opinion of many executives is that every company would/should take actions such of these to deliver earnings, as long as the real sacrifices are not too large and are within GAAP. We give four detailed examples of such decisions to highlight the sacrifice of long-term value to meet short-term 
earnings objectives. We emphasize that these examples do not lead to the firm violating GAAP or committing fraud.

- A CFO at a research-intensive firm indicates the role of "investment triggers" based on whether the firm's actual EPS would fall within or outside the range of earnings guidance. If the actual EPS comes in below the lower end of the guided EPS range, the "disinvestment trigger" would go off and the firm would eliminate or postpone R\&D spending (on positive NPV R\&D projects) until a later time. Conversely, if the actual EPS comes in above the higher end of the guided EPS range, the "investment trigger" would go off and the firm would invest the surplus earnings into R\&D projects (or take another action that would "bank" the earnings for the future). We asked why the firm would not take all the positive NPV R\&D projects, regardless of whether the reported EPS falls in the guided range or not. The CFO responded that the market has certain expectations about EPS growth from year to year and there is a trade-off between delivering EPS growth to the market and investing in R\&D projects that would payoff in the long run.

- A number of CFOs cite the example of funding pension plans. To cite one detailed instance, the firm had chosen a discount rate of 6.5\%-7.0\% at the end of calendar year 2002 to value its pension liability. The firm's fair value of pension assets, most of which was invested in U.S. equities, had lost value in recent years on account of the poor performance of the stock market. Hence, the fair value of the pension assets (FVPA) fell below the projected benefit pension obligation (PBO) but was higher than the accumulated pension benefit obligation (ABO). After interest rates fell in 2003, adopting a discount rate of around $5 \%$ would leave the firm with a large under-funded position on the pension plan (FVPA $<$ ABO). This would mean that the firm would lose its pre-funded pension asset from the 2003 balance sheet. The CFO acknowledged that loss of the pre-funded pension asset would attract the attention of analysts and investors. One way to avoid this outcome is to contribute cash to the pension plan. ${ }^{10}$ The CFO admits that the company had access to a number of positive NPV R\&D projects, the return on which would perhaps exceed the return on investing funds in the pension plan. It is remarkable that the desire to report a fully-funded pension asset potentially pressures firms into eliminating or postponing positive NPV investments.

- One CFO candidly admits that his/her company would defer or eliminate maintenance spending to meet earnings targets, even if such deferment would accelerate the need to replace the asset in the future. The CFO went on to illustrate how retrenching trained personnel might be economically sub-optimal in the long-run, but that his/her company has taken such actions to meet the earnings target. Similarly, another CFO mentioned that his/her firm would perform "band aid" maintenance for several years to protect earnings, even if a decision to take a hit to earnings and refurbish the plant all at once would have been NPV positive.

- Another example pertains to a company that would sell an internally developed patent to outsiders and recognize revenue or return to meet an earnings target, rather than develop the patent later in-house, even if the expected cash-flows associated with in-house development exceed the sale proceeds of the patent.

Consistent with the survey evidence, the interviews suggest that executives currently emphasize real economic actions rather than the exercise of accounting discretion to hit earnings benchmarks. ${ }^{11}$ The

\footnotetext{
${ }^{10}$ Moreover, pension accounting standards allow firms to reduce pension expense by an amount equal to the contribution times a management-assumed expected rate of return even if the actual rate of return earned by the pension assets is lower than the assumed expected rate of return.

${ }^{11}$ One CFO states that while it is preferable to manage earnings via real actions rather than accounting choices, it is also more difficult. That is, a CFO must understand the operations up and down the organization to effectively manage earnings via real actions. This CFO refers to earnings management via accounting actions as "laziness on
} 
interviews did uncover some evidence of accounting choices made to enhance the odds of hitting an earnings target, though the CFOs insist that these actions are well within the purview of GAAP (though they acknowledge that this does not always appear to be the case at other firms). One CFO argued that there is nothing wrong with exercising legal accounting discretion to project his/her company in a better light. Often-quoted examples of such accounting discretion include (i) booking reserves by recognizing more expenses this quarter than the next and drawing on such reserves to meet an earnings shortfall in the future; (ii) accelerating revenue recognition to book a deal this quarter rather than the next; (iii) changing the assumptions underlying the booking of litigation reserves; and (iv) changing the assumptions underlying recognition of asset impairment.

\subsection{Future reversals}

Many of the real and accounting actions mentioned above eventually unwind and affect earnings in future periods. ${ }^{12}$ Then, why do CFOs undertake such actions? When asked about this, most CFOs argue that in a growing firm the hope is that future earnings growth will offset reversals from past earnings management decisions. ${ }^{13}$ One interpretation of this action is that CFOs indulge in earnings management to signal the firm's future growth prospects (e.g., Ronen and Sadan 1981; 10). However, CFOs acknowledge that if the firm's financial condition continues to deteriorate for a period of time, small earnings management decisions can cascade and lead to big write-offs or large negative surprises in later periods.

Another CFO explains that when the overall economy is down, the firm makes choices that boost earnings. The reversal or the catch-up to this action does not kick in until the overall economy recovers and earnings are on the rise, so that the firm can pick up discretionary expenditures later without the catch-up being obvious to investors, or being painful because the firm is relatively flush in cash during the recovery.

\subsection{Earnings guidance}

CFOs indicate that they can manage earnings benchmarks via earnings guidance. The descriptive data reported in panel A, Table 1 shows that $80.7 \%$ of the survey participants provide some sort of guidance to analysts. Because archival data on earnings guidance is difficult to obtain, we provide descriptive

the part of the CFO" because much more effort is necessary to understand all aspects of the business in order to manage earnings via real actions.

${ }^{12}$ Several CFOs state that big baths often occur when there is a change in management teams. The new managers can blame the need for a write-off on the old management team, while at the same time reducing the earnings expected from the new management team.

${ }^{13}$ This is consistent with Lev's (2003) argument that one reason that financial executives manage earnings is that they are die-hard optimists who want to "weather the storm," believing that things will improve in the future. 
evidence on firm characteristics associated with guidance. ${ }^{14}$ The univariate correlations reported in Table 1 , panel B show that guidance is higher in firms with greater analyst coverage $(\rho=0.437, p<0.001)$, perhaps because analysts demand assistance in predicting earnings. Growth firms [firms that report higher sales growth $(\rho=0.231, \mathrm{p}<0.001)$ and in the technology sector $(\rho=0.12, \mathrm{p}<0.001)]$ are more likely to guide because meeting analyst expectations is important for the stock price trajectory of such firms (Sloan and Skinner 2002). Note that our comments on earnings guidance in the remainder of this section are drawn from interviews and not from survey evidence. Although we collect basic demographic data on the companies that provide earnings guidance, we did not ask detailed survey questions on guidance because of space constraints on the survey.

Many interviewed CFOs indicate that they often guide analysts to a different consensus estimate if there is a gap between their internal projections of where the firm might end up at the end of the quarter and the consensus number. An important reason for giving guidance is to ease the analyst's job in computing forecasted EPS. Otherwise, executives feel, analysts would go off and "do their own thing” and likely come back with more disperse earnings estimates. CFOs dislike dispersion in earnings estimates. Most CFOs guide analysts to a number that is less than the internal target so as to maximize chances of a positive surprise. In fact, the phrase "managing analysts' expectations" came up numerous times during the interviews. The rule of thumb that many firms try to follow is to "under-promise and over-deliver.”

Many CFOs deplore the culture of giving earnings guidance and meeting or beating the guided number. They argue that such a culture inhibits managers from thinking about long-term growth and, instead, makes them invest excess energy in beating quarterly targets. Yet, many of these same firms provide guidance because they view the practice as a "necessary evil.”

Several of the interviewed companies contemplate a reduction or elimination of earnings guidance. Providing guidance can be desirable when the company is stable and the executives feel that they will be able to meet or exceed the guided number. In this case, providing guidance reduces the chance of missing consensus (perhaps because the unguided consensus might be based on faulty information or, otherwise, unattainable). However, for an unstable company, missing a guided number is a very bad outcome because it implies that management has little control over the firm. For example, analysts might think that the firm is out of control, to the extent that management is unable to deliver an earnings number that they had guided to in the first place. The consequences would be less severe for missing an unguided number. CFOs dislike the prospect of coming in short on their numbers, particularly if they are guided numbers, in part because then the firm has to deal with extensive interrogations from

\footnotetext{
${ }^{14}$ Hutton (2003) analyses characteristics of firms that provide guidance in the pre-Regulation FD regime.
} 
analysts about the reasons for the forecast error, which limits the firm's opportunity to talk about long-run or strategic issues. As mentioned before, such questioning casts a pall over the entire conference call.

Most of the interviewed firms that had given up guidance had reported losses for several quarters. When the firm is unstable and reporting negative earnings, CFOs feel that they are better off talking about assumptions underlying the earnings process and the firm's performance relative to those assumptions, so that analysts can make their own earnings estimates. (We note that this can be thought of as "indirect guidance.”) While this may result in a wider range of earnings forecasts, there are fewer embarrassing last minute surprises of the nature: “whoops, we can not hit the earnings number that we guided you to.” In short, guidance is desirable if the firm is stable enough to deliver the guided number, but guidance is undesirable if the firm is unsure of its ability to deliver the guided earnings.

We also ask why analysts would let companies get away with meeting or beating consensus estimates quarter after quarter. Why do not analysts learn from past experience and change their consensus estimates in such a way that meeting or failing to meet the consensus eventually becomes a random unpredictable event? CFOs point out that analysts are complicit in the earnings game in two ways. First, if a firm is a "bellwether" stock, such that the stock prices of other firms in the same industry co-vary with the bellwether, then analysts might find it worthwhile to let the bellwether stock "look good" and beat the earnings estimates. Otherwise, they run the risk that the stock prices of other firms in the industry would fall if the bellwether firm did not meet the estimate, increasing the odds that the analyst might look bad with respect to those other firms and potentially causing trading losses for the investment arm of the analyst's firm. Second, analysts feel embarrassed that the firm does not meet or exceed their earnings prediction. As one CFO put it, "analysts viciously turn on you when you fail to come in line with their projections.”

As an interesting aside, when asked about whether they would prefer to meet or to beat the earnings target, several CFOs say they would rather meet (or slightly beat) the earnings target rather than positively surprising the market in a big way every quarter because (i) this could cause the firm to lose credibility, and (ii) providing large earnings this quarter might lead analysts and investors to "ratchet up" expectations for earnings in future quarters. Hence, many CFOs prefer to "bank" the excess earnings for use in later time periods. Another reason for such behavior -- the conjecture of a few CFOs -- is that the market hammers the stock price when the firm fails to meet the consensus estimate, but the stock price is relatively insensitive to the degree to which the target is exceeded. Such an asymmetric reward function creates incentives for managers to smooth earnings. The role of smoothing earnings is discussed next. 


\section{Smooth Earnings Paths}

\subsection{Preference for smooth earnings paths, keeping cash flows constant}

We ask CFOs about whether they prefer smoother or bumpy earnings paths, keeping cash flows constant. An overwhelmingly large $96.9 \%$ of the survey respondents indicate that prefer a smooth earnings path. We also observe a strong proclivity for smooth earnings paths, keeping cash flows constant, during the interviews. Such a strong enthusiasm for smooth earnings is not reflected in the academic literature. ${ }^{15}$

One interviewed CFO remarks, "businesses are much more volatile than what their earnings numbers would suggest." When asked specifically why they prefer a smoother earnings path, survey respondents feel that smoother earnings are perceived as less risky by investors (88.7\%, Table 8, row 1, see Figure 7). It is interesting that smooth earnings are perceived to result in lower cost of equity and debt: CFOs believe that investors demand a smaller risk premium for smooth earnings paths (57.1\%, Table 8, row 4), and smoother earnings paths also apparently achieve and preserve a higher credit rating (42.2\%, Table 8, row 7). Another frequently voiced explanation for a preference for smooth earnings is that smoother earnings make it easier for analysts and investors to predict future earnings (79.7\%, Table 8, row 2), and unpredictable earnings leads to a lower stock price (in the opinions of interviewed CFOs).

Intertwined with the risk premium idea are two other motivations to smooth earnings: (i) smoother earnings assure customers and suppliers that the business is stable, perhaps resulting in better terms of trade (66.2\%, Table 8, row 3); and (ii) smoother earnings convey higher growth prospects to investors (46.3\%, Table 8, row 5). There is no survey evidence that executives use smoother earnings to communicate true economic performance to outsiders (Table 8, row 8). This is in contrast to claims in the the academic literature that executives prefer to smooth out the noisy kinks in the unmanaged earnings process so that market participants can get a feel for the true underlying earnings process. Furthermore, there is no evidence that smoother earnings increase bonus payments (Table 8, row 9).

Conditional analyses reveal that the following types of firms feel that smooth earnings are perceived as less risky by investors: large firms, low P/E firms, and firms in the technology industry (Table 8, row 1). Reporting smoother earnings to ease analyst predictions of future earnings is viewed as more important in firms that give more guidance and have greater analyst following (Table 8, row 2). Believing

\footnotetext{
${ }^{15}$ Buckmaster $(2001,85)$ reports that only 8 articles related to smoothing have been published between 1982-1998 in the following three accounting journals: Journal of Accounting Research, The Accounting Review and Contemporary Accounting Research.
} 
that smoother earnings reassure stakeholders is more popular in smaller firms, firms in the technology sector, insider dominated firms, and firms that are private, not profitable and have less analyst coverage (Table 8, row 3). Kamin and Ronen (1978) also find that smoothing is more prevalent in ownercontrolled firms.

\subsection{Sacrificing value for smooth earnings}

When we directly ask respondents about how large a sacrifice in value they would make to avoid a bumpy earnings path, an astonishing $78 \%$ of the survey respondents state that they would sacrifice a small, moderate or large amount of value to achieve a smoother earnings path (Table 9, see Figure 8a and b). This finding is consistent with earlier evidence (discussed above) that CFOs would give up economic value to meet an earnings target. Conditional analyses, reported in panel $\mathrm{B}$, indicate modest crosssectional variation in the responses. Technology firms are more prone to making small sacrifices than non-technology firms, while insider-dominated firms are willing to make moderate sacrifices. Firms that provide much guidance are more willing to give up value to report smoother earnings paths, perhaps because inability to conform to reported guidance would have negative consequences, as discussed above.

To flush out the survey evidence, we turn to the interviews. The interviews reveal a persistent theme among CFOs: "the market hates uncertainty." Without exception, every CFO we spoke with prefers a smoother earnings path to a bumpier one, even if the underlying cash flows are the same. In general, this preference is as obvious to them as saying, "good is better than bad."

CFOs cite a number of stock-price related motivations for their desire to smooth earnings. First, they believe that the stock market values earnings predictability. Many CFOs state that their P/E multiples would drop if the earnings path were to become more volatile (even if cash flow volatility stays the same). They argue that the market expects a lower "risk premium” if the earnings path is steady (keeping cash flow path constant). When pressed further about why earnings volatility matters over and above cash flow volatility, a few CFOs state that the market becomes more skeptical of underlying cash flow volatility when earnings are volatile. Even if two firms had the same underlying cash flow volatility, the firm with the more volatile earnings would be perceived as riskier.

This risk premium is related to the asset pricing literature. First, CFOs seem to believe that estimation risk is important. ${ }^{16}$ That is, uncertainty about earnings could induce a perceived estimation risk in expected returns and higher moments used in portfolio selection. This estimation risk may lead to a higher risk premium. Second, both estimation risk and increased volatility are likely to be associated with more disagreement between analysts about earnings prospects. Recent research demonstrates that

\footnotetext{
${ }^{16}$ See Klein and Bawa (1976), Jorion (1985), Britten-Jones (1999) and Xia (2001).
} 
disagreement commands a risk premium. ${ }^{17}$ Third, in so much as volatile earnings spill over into volatile stock returns, the CFOs seem to indicate that idiosyncratic volatility is important. ${ }^{18}$ Fourth, Barry and Brown (1985, 1986) and Merton (1987) argue that when there is information asymmetry between managers and outside investors, investors demand an information risk premium. Recent papers in the accounting literature have argued that information risk stemming from poor disclosure and earnings quality is priced accordingly by the equity and debt markets. ${ }^{19}$

We note two additional asset-pricing explanations. First, predictability of earnings makes it easier for investors to get a sense for how much of the earnings will be paid out versus how much will be reinvested. Second, the firm has no obvious interest in increasing earnings volatility. CFOs feel that speculators, short-sellers and hedge funds are the only parties that benefit from higher volatility in the firm's earnings numbers and, consequently, in the firm's stock price. Related to the predictability point, one CFO goes to the extent of saying, "analysts want you to fill in the cells of their modeling spreadsheet for them.” Bumpy earnings streams throw their spreadsheets "out of gear," catch them off-guard and undermine their trust in the company and its numbers. Executives point out that the culture of "predictability in earnings" goes deep down the organizational hierarchy. Divisional managers develop reputations as "no surprise guys" by creating cushions in their revenue and spending budgets. These dependable managers are rewarded in the firm for the "sleep well” factor in their delivering of earnings.

CFOs equate the idea of smooth earnings with the desire to avoid negative earnings surprises (relative to earnings targets). In their mind, missing the consensus estimate and bumpy earnings are commingled, and both increase uncertainty in investors' perceptions about the firm. Several CFOs indicate that they would work aggressively within the confines of GAAP to reduce the perception of uncertainty about the firm's prospects. One executive cited the example of realizing a large unexpected gain on the sale of investments. Instead of reporting the gain in the quarter that it occurred, the firm purchased collars to smooth the gain gradually into the income over the next 10 quarters.

\subsection{Target audience}

We ask CFOs about the perceived marginal price-setter for their stock, which would reveal the target audience that executives have in mind when they set voluntary disclosure and earnings recognition policies. The survey evidence shows that CFOs view institutional investors, followed by analysts, as the most important marginal price setters of their stock (Table 10, rows 1 and 2, Figure 9). Individual investors are a distant third.

\footnotetext{
${ }^{17}$ See Diether, Malloy and Scherbina (2002) and Anderson, Ghysels and Juergens (2003). Also see Miller (1977).

18 See Goyal and Santa-Clara (2003) for a recent treatment.

${ }^{19}$ See Botosan (1997), Sengupta (1998) and Francis, LaFond, Olsson and Schipper (2002).
} 
Conditional analyses in panel B highlight several interesting facts. Firms with higher P/E ratios (growth firms) view institutions as more important price-setters of their stock, than do firms with lower $\mathrm{P} / \mathrm{E}$ ratios. Firms that are larger, have more analyst coverage and provide more earnings guidance view analyst reporting as important influences on their stock price. Individual investors are perceived as relatively more important by firms that are small, listed on NASDAQ/AMEX, covered by fewer analysts, and less active in guidance. Rating agency ratings have a bigger influence in firms that are larger, more highly levered, listed on NYSE, unprofitable, and provide more earnings guidance. Hedge funds are viewed as more active price setters by firms that do not provide much guidance.

During the interviews, CFOs mentioned that institutions and analysts constitute a more organized group of users of their guidance information than individual investors. Hence, it becomes harder to ignore the demands of institutions and analysts. Most CFOs believe that institutional investors set the stock price on the buy-side in the long run, that analysts affect short-term prices, and that retail investors are not often an important price setter. However, CFOs worry about the perceptions of retail investors because they are potential customers for the firm's products, as well as investors. That is, CFOs are concerned that missed earnings targets or bumpy earnings paths could affect the confidence of retail investors in the firm's products and financial stability, especially in a business like banking, where customer confidence is a major driver behind the firm's continued survival.

When asked why "sophisticated" investors, such as institutions and analysts, would not look beyond short-term earnings misses or a new bump in the earnings path, assuming that long-run prospects are relatively unaffected, interviewed CFOs respond in three ways. First, some point out that many players in the market today, especially youthful equity analysts, do not have a sense of history, in that they have not been in the market through more than one business cycle (market boom or bust). Referring to young equity analysts, one agitated CFO remarks, “I don't see why we have to place these disclosures in the hands of children that do not understand the information.” Such an absence of history makes analysts more prone to overreactions when the firm misses an earnings target or when a new kink appears in the earnings path. Second, fund managers are compensated on the basis of how their funds have done relative to peer managers. If one fund starts selling the firm's stock when the firm misses an earnings target, fund managers at peer firms have incentives to sell to protect their compensation. Thus, relative performance evaluation of fund managers is believed to promote momentum investing and less willingness to hold a stock for the long run. Third, the number of traders who try to profit on day-to-day movements in the stock price has increased in recent times (e.g., hedge funds). If a firm misses an earnings target, this might trigger automatic sell programs, which will drive the price lower. One CFO points out that many investors "sell first and ask questions later." Finally, when we ask CFOs to explain why earnings misses and the related negative reactions of individual firms ought to matter to a diversified investor, they respond that 
“these investors diversify by holding less of our stock and more of someone else's," indicating again that managers believe that idiosyncratic risk matters.

\section{Voluntary disclosure decisions}

Voluntary disclosure policies are integral to the quarterly earnings reporting process, which has been the focus of the paper thus far. Voluntary disclosures take various forms: press releases (especially for new product introductions and awards), investor and analyst meetings, conference calls, monthly newsletters, field visits with existing and potential institutional investors, and the disclosure of more than mandated information in regulatory filings, such as in the 10-Q or 10-Ks (e.g., adding an extra line in financial statements to separate core from non-core items). Firms voluntarily disclose information not required by the SEC and the FASB in an effort to shape the perceptions of market participants and other stakeholders and, hence, to benefit from improved terms of exchange with these parties. Healy and Palepu (2001), who review the academic literature related to voluntary disclosure, identify firms' motivations to disclose voluntarily information as an important unresolved question for future research. A substantive portion of the survey and interviews are dedicated to voluntary disclosure. Our findings are summarized in the following paragraphs.

\subsection{Why voluntarily disclose information?}

We examine five motivations that the literature has identified as driving managers' voluntary disclosure decisions (information asymmetry, increased analyst coverage, corporate control contests, stock compensation, and management talent) and four constraints on voluntary disclosure (litigation risk, proprietary costs, political costs, and agency costs) (see Healy and Palepu, 2001). We also introduce two drivers of voluntary disclosure that have not received extensive attention in the literature: the limitations of mandatory disclosure, and setting a disclosure precedent that may be hard to maintain.

\subsubsection{Information asymmetry}

Barry and Brown $(1985,1986)$ and Merton (1987) argue that when there is information asymmetry between managers and outside investors, investors demand an information risk premium. Firms can reduce their cost of capital by reducing information risk through increased voluntary disclosure. Diamond and Verrecchia (1991) and Kim and Verrecchia (1994) suggest that voluntary disclosure reduces information asymmetry between uninformed and informed investors, and thus increases the liquidity of a firm's stock. We ask the executives whether the cost of capital or reduction of information risk is a 
motivation for voluntary disclosures. More than four-in-five respondents agree or strongly agree with the information risk motivation (Table 11, row 2, see Figure 10). In a related question, when asked whether voluntary disclosures increase the predictability of their companies' future prospects, $56.2 \%$ agree (Table 11, row 4). The importance of predictability is consistent with the earlier theme that the market hates negative earnings surprises. In fact, predictability of financial results appears to be a unifying, overarching theme between quarterly earnings reporting and voluntary disclosure decisions.

Many interviewed CFOs state that reducing uncertainty about the firms' prospects is the most important motivation for making voluntary disclosures. The executives distinguish between "information risk" and "inherent risk." As one CFO puts it, "information risk is the risk that the market does not have all the pertinent information about an event or the uncertain cash flows of our firm, whereas inherent risk relates to the uncertainty associated with the underlying cash flows.” This CFO believes that voluntary disclosures reduce the information risk associated with the company, especially if they make the earnings number more "predictable.” CFOs also mention that releasing bad news can be beneficial if it reduces information risk more than it reduces expectations about cash flows. In essence, eliminating information risk tightens the distribution of perceived cash flows, leaving only inherent risk to affect stock prices, potentially reducing the risk premium investors demand to hold the company’s stock.

Another advantage of releasing bad news is that it can help a firm develop a reputation for providing timely and accurate information to the marketplace. CFOs place a great deal of importance on acquiring such a reputation: $92.1 \%$ of the survey respondents believe that developing a reputation for transparent reporting is the key factor motivating voluntary disclosures (Table 11, row 1). Many interviewed executives feel that the primary role of voluntary disclosure is to correct investors' perceptions about current or future performance, so that the stock is priced off company-provided information rather than misinformation (or "rumors" as one CFO put it). One CFO mentions that such a reputation buys him/her "flexibility to take strategic actions that the Street would trust." Another CFO points out that voluntary disclosures help the firm cultivate relationships with institutional investors, and such relationships may "parlay into easier access to capital in the future or a lower cost of capital."

Although only 39.3\% agree with the cost of capital motive behind financial disclosure, the difference between the percentage of those who agree and disagree is statistically significant (Table 11, row 9). In the interviews, roughly the same proportion of executives confirms the direct link to the cost of capital. (Several CFOs link reduction in the dispersion of analyst estimates and subsequent reduction in the cost of capital.) In the interviews, more executives think of the relation as one of receiving a "P/E lift" due to greater voluntary disclosures. (While a P/E lift should reduce the cost of capital, more interviewed CFOs recognize the $\mathrm{P} / \mathrm{E}$ lift than the cost of capital reduction.) Several CFOs believe that this $\mathrm{P} / \mathrm{E}$ lift happens because voluntary disclosures enhance the firm's reputation for transparent reporting. The "P/E lift" 
related motivation gets modest survey support, with $42 \%$ of the respondents believing this and $18 \%$ not (Table 11, row 8), a statistically significant difference.

During the interviews, CFOs of companies with smaller market capitalizations suggest that liquidity of their firm's stock improves when they make voluntary disclosures. The survey evidence reveals support for the liquidity motivation (44.3\%, Table 11, row 7), especially among small firms.

Other conditional analyses provide the following insights. Large firms are more concerned about the predictability of future prospects and reducing the cost of capital. Small firms care more about using disclosure to increase the liquidity of their stock. Not surprisingly, low P/E firms care about the cost of capital motivation of voluntary disclosures (Table 11, row 9). High growth firms are interested in using voluntary disclosures to communicate the predictability of future growth prospects (Table 11, row 4). Highly levered firms care about predictability of future prospects and the cost of capital motivation (Table 11, row 4 and 9). Firms with large analyst coverage view the reputation for transparent reporting, reducing information risk, increasing predictability and a reduction in the cost of capital as relatively important motivations for voluntary disclosures (Table 11, row 1, 4, 8 and 9).

\subsubsection{Increased analyst coverage}

Bhushan (1989a, b) and Lang and Lundholm (1996) argue that if management's private information is not fully revealed through required disclosures, voluntary disclosure lowers the cost of information acquisition for analysts and increases the amount of information available to analysts. The survey results reports some support for this motivation (50.8\%, Table 11, row 5). Small firms and insider-dominated firms are more interested in using disclosure to attract more analysts.

\subsubsection{Corporate control}

Healy and Palepu (2001) hypothesize that the risk of job loss accompanying poor stock and earnings performance encourages managers to use corporate disclosures to reduce the likelihood of undervaluation and the need to explain away poor earnings performance. Survey evidence provides moderate support for this hypothesis (48.4\%, Table 11, row 6). Conditional analyses reveal that unprofitable firms and young firms care more about this motivation than profitable and older firms.

\subsubsection{Stock compensation}

Evidence linking voluntary disclosure to compensation (e.g., Noe (1999), Aboody and Kasznik (2000), and Miller and Piotroski (2000)) relies on one of the following theoretical arguments. First, managers have incentive to disclose private information to meet restrictions imposed by insider trading 
rules and to correct perceived under-valuation (relative to their own information set) and to increase liquidity of the firm's stock. Second, managers acting in the interest of existing shareholders have incentive to reduce contracting costs associated with stock compensation for new employees. Otherwise, employees will demand a risk premium to shield them from the information advantage held by managers. The survey evidence does not support the latter of these arguments. In fact, half of the respondents disagree or strongly disagree with the idea that voluntary disclosures are made to reduce the risk premium demanded by employees for holding stock granted as compensation (Table 11, row 11). There is modest conditional support for this motivation in the technology sector, where stock compensation is likely more prevalent.

\subsubsection{Management talent signaling hypothesis}

Trueman (1986) argues that a talented manager has incentive to make voluntary disclosures to signal his or her type. The survey evidence for this motivation is statistically significant, although this motivation ranks near the end in terms of importance (41.3\% for and $26.1 \%$ against, Table 11, row 10). No interviewed CFO explicitly mentioned the role of talent signaling while discussing their motivations to voluntarily communicate information to the market. Conditional analyses indicate that this motivation is relatively more important for managers of smaller and high growth firms.

\subsubsection{Limitations of mandatory disclosures}

A surprisingly high $72.1 \%$ of the respondents feel that voluntary disclosures correct gaps in the usefulness of mandatory financial disclosures to investors. Conditional analyses reveal that this concern is more severe for firms that are large, high-growth, highly levered and well covered by analysts (Table 11, panel B, row 3), perhaps because their businesses and the associated mandatory disclosures are complex. This motivation for voluntary disclosure does not get significant attention in the academic literature. As one interviewed CFO puts it, prescribed disclosures from the FASB “confuse rather than enlighten” the users of financial statements. An executive of a financial institution makes the incredible remark: "some of our own footnotes related to off-balance sheet items and securitizations are so complex, even I don't understand them.” CFOs point out that mandated summary financial statements are reported once a quarter and, hence lack timeliness. Moreover, mandatory statements ignore leading non-financial indicators of future earnings, such as the product pipeline. CFOs state that GAAP-based financial reporting ignores intangible assets such as "people, processes and our brand position.” Lev (2001) discusses accounting and disclosure issues related to intangibles. In the literature, Bushee, Matsumoto and 
Miller (2003) and Tasker (1998), among others, argue that less informative financial statements create incentives for more voluntary disclosure.

\subsection{Constraints on voluntary disclosures}

We investigate which factors constrain voluntary disclosures, with results summarized in Table 12 (see Figure 11).

\subsubsection{Disclosure precedent}

The most common reason that executives limit voluntary disclosure is related to setting a precedent. More than two-thirds of the survey participants (69.6\% in Table 12, row 1) agree or strongly agree that a significant constraint to more disclosure is the desire to avoid setting a disclosure precedent that is difficult to maintain in the future (Bushee, Matsumoto and Miller 2003). Conditional analyses, reported in panel $\mathrm{B}$, reveal that setting disclosure precedents is a bigger issue among insider-dominated firms. ${ }^{20}$ We are not aware of a systematic exploration in the literature of the precedent constraint to voluntary disclosure.

Several interviewed CFOs state that they would not make an earnings forecast or start making voluntary disclosures of non-financial leading indicators for fear of starting a practice that they might later want to abandon. One CFO likened this process to "getting on a treadmill” that you could not get off. The market then expects the company to maintain the newly initiated disclosures every quarter, regardless of whether the news is good or bad.

\subsubsection{Litigation costs}

The literature argues that the threat of litigation can affect voluntary disclosures in two ways. First, the threat of litigation can induce managers to disclose information, especially bad news (Skinner 1994, 1997, Francis, Philbrick and Schipper 1994). Second, litigation can potentially reduce managers’ incentives to provide forward-looking disclosures. The survey provides moderately supportive evidence: $46.4 \%$ of the respondents agree or strongly agree with the litigation cost hypothesis (Table 12, row 3 ). Conditional analyses, reported in panel B of Table 12, reveal that litigation costs are a major concern for firms that are young, listed on NASDAQ or AMEX, or in the technology sector.

\footnotetext{
${ }^{20}$ This could be interpreted as insiders trying to protect their 'insider' advantage. In addition, extra disclosure might limit the ability to delay the release of bad news (Niehaus and Roth 1999) or earnings management in general (Beneish, Press and Vargas 2004) after insider selling.
} 
One interviewed CFO points out short-run volatility in a stock attracts class-action lawyers who have computer programs that identify firms (for potential law suit) whose stock prices fall more than $20 \%$ in a few days. The CFO laments that the Safe Harbor legislation passed in the late 90s has had virtually no effect on lawsuits. It is not as much a question of whether a firm can win or lose a lawsuit, because most of them get settled out of court. Executives believe that class-action lawyers target a settlement that is slightly smaller than the cost of going to court. The press coverage associated with the potentially frivolous lawsuit is another deterrent. We revisit the litigation hypothesis in Section 6.3, where we investigate factors that encourage firms to report bad news quickly.

\subsubsection{Proprietary cost hypothesis}

Several researchers argue that we do not observe corner solutions to the voluntary disclosure issue (i.e., full disclosure) due to proprietary costs, reflecting concern that some disclosures might jeopardize the firm's competitive position in the product market (see Verrecchia (2001) and Dye (2001)). Nearly three-fifths of survey respondents agree or strongly agree that giving away company secrets is an important barrier to more voluntary disclosure (Table 12, row 2). Conditional analyses, reported in panel B, reveal that small firms and those listed on NASDAQ or AMEX and that provide little earnings guidance are more worried about proprietary costs. There is also interview support for the proprietary cost hypothesis. A few CFOs cite proprietary costs as a significant barrier to more disclosure. CFOs do not want to explicitly reveal sensitive proprietary information "on a platter" to competitors, even if such information could be partially inferred by competitors from other sources, such as trade journals or trade

conferences. The survey evidence indicates that proprietary costs are a very important factor limiting voluntary disclosures.

\subsubsection{Agency costs}

Agency issues are generally not addressed in proprietary cost models, and hence all voluntary disclosures are deemed to be credible (Healy and Palepu 2001). Agency issues may represent an important tension that explain lack of full disclosure, as suggested by Nagar, Nanda and Wysocki (2003) and Berger and Hann (2003). The survey evidence, however, provides no support for the agency story. An insignificant proportion of respondents agree that their firms limit voluntary disclosures to avoid potential follow-up questions about other unimportant items (Table 12, row 4). When we specifically ask whether avoiding unwanted scrutiny from bondholders and stockholders is a constraint on voluntary disclosure, the majority of the survey participants reply that unwanted scrutiny is not an important factor (Table 12, row 6). Perhaps survey participants are unwilling to acknowledge agency costs in a survey. 


\subsubsection{Political costs}

Although the positive theory literature emphasizes the role of political costs in accounting and disclosure decisions (Watts and Zimmerman 1978, 1986), the survey evidence does not provide much support for the political cost argument. A majority of survey participants disagree or strongly disagree with the hypothesis that avoiding unwanted attention from regulators is a significant barrier to voluntary disclosure (Table 12, row 5). Firms with high inside ownership are more concerned about regulatory scrutiny, although the absolute magnitude of concern is still modest.

\subsection{Bad news versus good news}

The accounting literature has long recognized that managers have incentive to differentially disclose good news versus bad news (e.g., Pastena and Ronen 1979; Skinner 1994, 1997; Francis, Philbrick and Schipper 1994). The survey evidence is fairly asymmetric in terms of the timing of the disclosure of good news and bad news. 52.9\% of the survey respondents give no preferential treatment to disclosing good or bad news faster (panel A of Table 13, see Figure 12). Another 20.5\% (26.6\%) of the sample claims that they release good (bad) news faster. In untabulated analyses, relative to profitable firms, unprofitable firms are less inclined to release bad news faster. For example, the sales growth rate of firms that say they release bad news faster is $9.4 \%$, compared to $-0.9 \%$ for firms that release good news faster.

When asked detailed questions about the reasons for the preference between good and bad news, $76.8 \%$ of the respondents say that they reveal bad news faster to reduce the possibility of a lawsuit resulting from failure to disclose timely information (e.g. unfavorable news) to the market (Table 13, panel B, row 2). This finding is consistent with the intuition in Skinner (1994, 1997). Conditional analyses, reported in panel $\mathrm{C}$, reveal that this concern is more pronounced among low P/E firms. One interviewed CFO stated that he/she attempts to pre-empt bad news revelations from other sources. The thinking is that it is better that the news comes from the firm rather than from outside sources. This would enable the firm to position the bad news in the best possible light.

During the interviews, CFOs indicate that both good news and bad news need to be communicated in a timely manner to "build credibility with the market," as one CFO put it. The survey data confirms that intuition as $76.8 \%$ of the respondents agree or strongly agree that disclosing bad news faster enhances the firm's reputation for transparent and accurate reporting (Table 13, panel B, row 1). At the same time, in the interviews some CFOs admit that they do not mind "fuzziness" in bad news disclosures. 
Several interviewed CFOs argue that they delay bad news in order to further study and interpret the information, or in hopes that the firm's status will improve before the next required information release, perhaps saving the company the need to ever release the bad information (e.g., interest rates might rise before year-end, correcting a current imbalance in pension funding). The survey provides strong support for delaying bad news to allow analysis and interpretation: Two-thirds of executives agree or strongly agree with this assertion (panel B, row 3). Some interviewed CFOs also point to the possibility of packaging bad news with other disclosures. However, only 35.5\% of surveyed CFOs agree or strongly agree with this possibility (panel B, row 4).

\section{Other issues}

The interviews addressed several issues related to disclosure and earnings management that we eliminated from the survey due to space constraints. We briefly summarize these observations below.

\subsection{Credit agencies versus equity analysts}

All the CFOs we spoke to indicate that they share much more detailed information with credit rating agencies than with equity analysts or institutional investors (one CFO refers to this as the "openkimono" policy). The executives mention that such selective disclosure to credit agencies is not a violation of Regulation FD. Many CFOs note that although credit agencies are not technically insiders, they have access to more information than do stock analysts. As expected, much of the information shared with credit agencies relates to liquidity on the balance sheet and the sources and uses of cash flow, especially related to capital expenditure, dividends and share repurchase plans in forthcoming time periods. However, due to their status as pseudo-insiders, rating agencies are privy to inside information, such as the firm's internal EPS projections. Consistent with expectations, cash-rich firms view credit rating agencies as somewhat less important than equity analysts; the importance of credit agencies increases as the firm approaches financial distress and/or becomes at-risk to receive a speculative rating. Some view credit rating agencies as valuable because they enhance the firm's reputation by assigning a credit rating and, thereby, affecting the cost of raising debt.

\subsection{Recognition versus disclosure}

Managers often express a preference for disclosing an item in the footnote rather than recognizing the item in the income-statement or the balance sheet (see Bernard and Schipper 1994). Among the interviewed CFOs, almost all feel that the market pays more attention to earnings number reported in the income-statement than in financial footnotes. Hence, if GAAP provides a choice, CFOs prefer placing 
items they would like to highlight to investors in the main body of the financial statements. All CFOs felt that retail investors do not understand the implications of footnote data very well, but that institutional investors and analysts appreciate and more fully understand footnote information. ${ }^{21}$ However, some feel that the footnotes are too complex even for qualified accountants to fathom.

When asked about stock option compensation, almost all CFOs consider option expenses to be operating costs that should be expensed. Many of our interviewees have already started expensing options, while others are waiting to see what their competitors do and the FASB's expected expensing rule, before deciding to expense options themselves. CFOs that have not committed to expense options believe that they would suffer a disadvantage if they expense options and their competitors do not (because their EPS numbers would be lower). These comments indicate a belief that the market is fixated on the bottom-line earnings number. Many executives also believe that the number of options given out to rank and file employees will fall if option expensing is mandated by the FASB. Indeed, a recent survey indicates that the use of options will fall at nearly two-thirds by public corporations in 2004 (Graham and Harvey, 2003).

A CFO from the financial services industry remarks that the distinction between recognized and disclosed items is not crucial for his/her company, as long as the item is considered for computing statutory capital. This suggests a rational explanation for why a majority of the firms that expense stock options belong to the financial services industry (see Aboody, Barth and Kasznik 2003; Daniel, Kale, and Naveen 2003). If option expensing is ignored for the purpose of calculating statutory capital, then expensing may not have major economic implications for financial services firms.

We also explore whether the desire to present items in the footnote differs depending on whether the item is income-increasing or income-decreasing in nature. However, we do not find much support for the idea that managers asymmetrically prefer to recognize income-increasing items and disclose incomedecreasing items in footnotes. When pressed about the potential link between EPS-based compensation schemes and the motivation to recognize or disclose information, CFOs indicate that compensation concerns are a second-order driver of the recognition/disclosure decision. There would surely be a mechanical reduction in EPS, and hence an EPS-linked bonus, if the firm moved an income-decreasing item from the footnote to the income statement. However, in many such instances, either the bonus requirements would be changed or a one-time supplemental bonus would be paid.

\subsection{Effect of Sarbanes-Oxley legislation}

${ }^{21}$ One CFO stated that "retail investors do not read this information, and they would not understand it if they did." 
CFOs of many companies believe that something needed to be done to address accounting abuses witnessed during the late 90s dot com boom, but they believe the Sarbanes-Oxley (S-Ox) legislation is overkill that adds substantially to operating costs. An executive of a large firm states that his firm hired six new employees merely to manage the new reporting obligations required by S-Ox and related legislation. Many CFOs deplore the "sub-certification" process created by S-Ox. While S-Ox requires CEOs and CFOs to certify the financial statements, at many companies that we talked to, CEOs and CFOs require divisional managers to "sub-certify" their divisional financial statements, and that process goes right down the line in the firm. One executive said that over 300 people had to sub-certify at his firm. As one executive put it, “the CEO used to look at the numbers over lunch and say, 'Let's go with it.' Now, the multi-layers of certification take much more management time.” One CFO felt that the FASB focus on rules-based as opposed to principles-based accounting standards was a key factor that contributed to accounting shenanigans in the late 90s. As he puts it, “over-emphasis on rules drives bad decisions.”

In general, interviewed CFOs feel that the changes under S-Ox, while well intentioned, will not change the market's desire for smooth earnings and for avoiding misses related to earnings targets. One CFO felt that "once this certification and other such requirements become routine, people will slip into their old ways.” Several CFOs comment that S-Ox inhibits operational risk-taking by (i) attempting to second-guess actions taken by management; and (ii) pushing companies to expense options (which might force firms to cut back the number of options granted and, hence, reduce incentives for risk taking). Reducing incentives for operational risk taking is thought to have resulted in unintended costs to S-Ox in the form of reduced entrepreneurial activity.

\subsection{Regulation FD}

Every interviewed CFO indicates that disclosure today involves the simultaneous posting of news on the company's website to comply with Regulation FD. One CFO mentioned that FD forces his/her company to come up with a more structured communication policy with investors. CFOs are somewhat mixed in their assessment of FD on information disclosure and dissemination. Some feel that FD has reduced the total amount of information disclosed, while others feel that they disclose the same information they did before FD. Almost all feel that the dissemination of information has become broader since FD. ${ }^{22}$ Conference calls and even lunches with select analysts are now web cast. One CFO of a Fortune 500 company mentioned that more than 1,000 outsiders routinely listen in on the conference call. Some CFOs indicate that, after FD, they prefer to bundle voluntary disclosures with the earnings press

\footnotetext{
${ }^{22}$ Several CFOs point out that, as one put it, "the breadth of information coverage has increased but the quality of information has decreased” under FD.
} 
release. Thus, the information content of earnings releases might have increased since FD, if this statement can be generalized to a larger sample. Stand-alone press releases are not preferred because there is no opportunity for dialogue with the investing public. Combining voluntary disclosures with the earnings press release allows CFOs to use the conference call to clarify questions or concerns that investors and equity analysts might have about the disclosure.

Although FD ensures complete dissemination of explicitly disclosed information to all parties, the practice of implicit guidance to analysts is alive and well. One CFO remarks "you can do things such as not answer a question an analyst poses, or say something with a grimace or a slight smile without explicitly violating FD.”

\subsection{Conglomerates}

We inquired about operating in conglomerate form for two reasons. First, a conglomerate business provides diversification and smoother cash flows. Second, the CFOs' opinions here could reveal important collaborating evidence regarding the agency explanation of earnings smoothing. That is, our survey tells us that economic value is often sacrificed for smoother earnings. One explanation is that smoother earnings extend management's tenure.

Most CFOs feel that conglomerates are priced at a discount (relative to the value their divisions could attain if they were stand-alone business units). This discount occurs because the benefits and synergies from operating as a conglomerate form are smaller than the costs. The biggest cost is management's inability to manage businesses in many disparate industries simultaneously. When we inquire why conglomerate firms do not then downsize and spin-off divisions, the primary answers are (i) ego (managers like to manage big companies), (ii) job security (downsizing will likely mean the loss of jobs

for some managers), and (iii) earnings smoothing (if the divisions are somewhat counter-cyclical, the earnings ups and downs offset each other and produce smoother earnings at the consolidated corporate level). Hence, the responses are consistent with our survey evidence: economic value is sacrificed to smooth earnings. In addition, a number of CFOs believe that job security is at least as important a motivation.

\section{Summary and Conclusions}

This paper reports financial executives’ opinions and motives about voluntary disclosure and earnings management. We believe that the evidence gathered via interviews and surveys adds to our understanding along four different dimensions. First, we report stylized facts about financial reporting issues. Second, executives rank-order the descriptive validity of academic theories of why managers make voluntary 
disclosures or manage reported earnings numbers. Third, the interviews and surveys suggest new explanations for several phenomena that have not received extensive attention in the academic literature. Fourth, we identify simple heuristics that determine the context in which executives make financial reporting decisions.

In terms of stylized facts, we find that financial officers view earnings, not cash flows, as the most important metric reported to outsiders. Managers care about earnings benchmarks, especially the seasonally lagged quarterly earnings number and the analyst consensus estimate. A majority of the CFOs view institutional investors as the primary party that sets the price of their stock. A large proportion of our respondents provide earnings guidance to equity analysts. Although Regulation FD prevents firms from sharing differential information with market participants, some provide implicit guidance to equity analysts. Firms are much more willing to share information with credit agencies than equity analysts.

We find that managers want to meet or beat earnings benchmarks to (i) build credibility with the capital market; (ii) maintain or increase stock price; (iii) improve the external reputation of the management team; and (iv) convey future growth prospects. The traditional explanations for hitting benchmarks, such as employee bonuses or influencing credit ratings, do not get much survey support. Failure to hit earnings benchmarks creates uncertainty about a firm's future prospects, and signals potentially hidden, deeper problems at the firm. Moreover, managers are concerned about spending considerable time after the earnings announcement explaining why they missed the benchmark, rather than presenting their vision of the firm's future.

Managers candidly admit that they would take real economic actions such as delaying maintenance or advertising expenditure and would even give up positive NPV projects to meet earnings benchmarks. To our knowledge, such unambiguous managerial intent to burn economic value to meet financial reporting goals has not been previously documented. Surprisingly, executives are more reluctant to employ accounting discretion, such as accrual management, to meet earnings targets, although accrual management is likely cheaper than giving up economic value. This tendency to substitute real economic actions in place of accounting discretion might be a consequence of the stigma attached to accounting fraud in the post-Enron and post-Sarbanes-Oxley world.

Keeping the path of the firm's cash flows constant, almost all financial officers prefer a smoother earnings path to a more volatile path. Smoother earnings paths are perceived as less risky by investors, according to the CFOs. Moreover, smoother earnings improve the predictability of future earnings, which in turn increases stock price, and also reassure suppliers and customers that the business is stable. There is not much support for the traditional economic argument that smoothing out kinks in the firm's earnings process helps managers communicate the true economic performance of the firm to outsiders. The 
consequences of a failure to smooth earnings are perceived to be severe. In fact, three-fourths of managers are willing to give up small or moderate economic value to achieve smooth earnings paths. In sum, there appears to be a strong preference for smooth earnings among managers, although this issue is relatively under-developed in extant academic literature.

Firms make voluntary disclosures for three main reasons: (i) to promote a reputation for transparent reporting; (ii) to reduce the information risk assigned to the firm's stock; and (iii) to address the deficiencies of mandatory reporting. The biggest barriers to voluntary disclosure are fear of setting a disclosure precedent that may be difficult to maintain in the future and concerns about giving up proprietary information to competitors. Managers state that they release bad news faster than good news to promote a reputation of transparent reporting with the capital market and to avoid potential lawsuits, though bad news is sometimes delayed to allow in-depth analysis, interpretation and consolidation into larger news releases.

Executives seem to employ simple decision rules or heuristics in response to a handful of widely held beliefs about how outsiders and stakeholders will react. These "rules of the game" help determine the playing field for many of earnings management and disclosure decisions. The rules of the game include the following: (i) the P/E multiple falls if you fail to hit the earnings benchmark or if the earnings are not sufficiently smooth; (ii) everybody manages earnings to hit targets, so if you do not, you will get hurt; (iii) because everybody manages earnings, if you miss the benchmark, you have revealed previously hidden problems at the firm, which worsens the perception of future growth prospects; (iv) managers try to maximize smoothness in earnings - volatile earnings are bad because they convey higher risk and/or lower growth prospects; and (v) voluntarily disclose market-moving information because doing so results in lower information risk. We believe that future research can fruitfully explore in greater depth why and how these rules are selected and implications of these rules for financial reporting policies. 


\section{References}

Aboody, D., and R. Kasznik. 2000. CEO stock options awards and the timing of corporate voluntary disclosures. Journal of Accounting and Economics 29, 73-100.

Aboody, D., M. Barth and R. Kasznik. 2003. Factors associated with firms' decisions to improve earnings quality: The voluntary recognition of stock-based compensation expense. Working paper, UCLA and Stanford University.

Anderson, E.W., E. Ghysels, and J. Juergens. 2003. Do heterogeneous beliefs and model uncertainty matter for asset pricing? Working paper, University of North Carolina at Chapel Hill.

Barry, C. and S. Brown. 1985. Differential information and security market equilibrium. Journal of Financial and Quantitative Analysis 20, 407-422.

Barry, C. and S. Brown. 1986. Limited information as a source of risk. The Journal of Portfolio Management 12, $66-72$.

Barth, M., J. Elliot and M. Finn. 1999. Market rewards associated with patterns of increasing earnings. Journal of Accounting Research, 37: 387-413.

Bartov, E. 1993. The timing of asset sales and earnings manipulation. The Accounting Review. 68 (4): 840-855.

Bartov, E., D. Givoly and C. Hayn. 2002. The rewards to meeting or beating earnings expectations, Journal of Accounting and Economics, 33(2): 173-204.

Beneish, M.D. 2001. Earnings management: A perspective. Managerial Finance 27, 3-17.

Beneish, M.D., E. Press and M.E. Vargas, 2004. Insider trading and incentives to manage earnings. Working paper, Indiana University.

Berger, P. and R. Hann. 2003. Segment disclosures, proprietary costs, and the market for corporate control. Working paper, University of Chicago and University of Southern California.

Bernard, V. and K. Schipper. 1994. Recognition and disclosure in financial reporting. Working paper, University of Michigan and FASB.

Bens, D., V. Nagar, D. Skinner and F. Wong. 2003. Employee stock options, EPS dilution, and stock repurchases. Journal of Accounting and Economics, Vol. 36, No. 1-3 (forthcoming)

Bhojraj, S. and R. Libby. 2004. Managerial myopia and disclosure frequency. Working paper, Cornell University.

Bhushan, R. 1989a. Collection of information about publicly traded firms: theory and evidence. Journal of Accounting and Economics 11, 183-207.

Bhushan, R. 1989b. Firm characteristics and analyst following. Journal of Accounting and Economics 11 (2-3), 255-275.

Bushee, B. 1998. The influence of institutional investors on myopic R\&D investment behavior. The Accounting Review73 (3): 305-333.

Bushee, B., D. Matsumoto and G. Miller. 2003. Open versus closed conference calls: the determinants and effects of broadening access to disclosure. Journal of Accounting and Economics, 34(1-3): 149-180.

Botosan, C.A., 1997. Disclosure level and the cost of equity capital. The Accounting Review 72 (3), 323-350.

Bowen, R., L. Ducharme, and D. Shores. 1995. Stakeholders implicit claims and accounting method choice. Journal of Accounting and Economics 20, 255-295.

Brav, A., J.R. Graham, C.R. Harvey and R. Michaely. 2004. Payout policy in the $21^{\text {st }}$ century. Working paper, Duke University and Cornell University.

Britten-Jones M. 1999. The sampling error in estimates of mean-variance efficient portfolio weights. Journal of Finance, 54, 655-671.

Brown, L. and M. Caylor. 2003. A temporal analysis of earnings management thresholds. Working paper, Georgia State University. 
Buckmaster, D. 2001. Development of the Income Smoothing Literature 1893-1998: A Focus on the United States. Studies in the Development of Accounting Thought. Eds: Gary Previts and Robert J. Bricker.

Burgstahler, D. 1997. Incentives to manage earnings to avoid earnings decreases and losses: Evidence from quarterly earnings. Working paper, University of Washington, Seattle.

Burgstahler, D., and I. Dichev. 1997. Earnings management to avoid earnings decreases and losses. Journal of Accounting and Economics 24, 99-126.

Daniel, N., J. Kale and L. Naveen. 2003. Do option expensing announcements convey information to the stock market? Working paper, Georgia State University.

Dechow, P. and R. Sloan. 1991. Executive incentives and the horizon problem: An empirical investigation. Journal of Accounting and Economics 14:51-89.

Dechow, P. and D. Skinner. 2000. Earnings management: Reconciling the views of accounting academics, practitioners, and regulators. Accounting Horizons 14(2): 235-250.

DeGeorge, F., J. Patel and R. Zeckhauser. 1999. Earnings management to exceed thresholds. Journal of Business 72(1): $1-33$

Diamond, D., and R. Verrecchia. 1991. Disclosure, liquidity, and the cost of capital. The Journal of Finance 66, 1325-1355.

Diether, K.B., C. Malloy and A. Scherbina. 2002. Differences of opinion and the cross-section of stock returns. Journal of Finance 57, 2113-2142.

Dye, R. 2001. An evaluation of "essays on disclosure" and the disclosure literature in accounting, Journal of Accounting and Economics 32 (1-3): 181-235

Erickson, M., M. Hanlon and E.L.Maydew. 2004. How much will firms pay for earnings that do not exist? Evidence of taxes paid on allegedly fraudulent earnings. Accounting Review (forthcoming).

Fields, T., T. Lys and L. Vincent. 2001. Empirical research on accounting choice. Journal of Accounting \& Economics. 31, 255-307.

Flanagan, John C. 1954. The critical incident technique. Psychological Bulletin 51, 327-358.

Francis, J., D. Philbrick, and K. Schipper. 1994. Shareholder litigation and corporate disclosures. Journal of Accounting Research 32, 137-165.

Francis, J., R. LaFond, P. Olsson and K. Schipper. 2002. The market pricing of earnings quality. Working paper, Duke University.

Goyal, A., and P. Santa-Clara. 2003. Idiosyncratic risk matters! Journal of Finance 58, 975-1007.

Graham, J. R., and C. R. Harvey. 2001. The theory and practice of corporate finance: Evidence from the field, Journal of Financial Economics 60, 187-243.

Graham, J. R., and C. R. Harvey. 2003. The Financial Executives International/Duke University CFO Outlook Survey: 1996-2003. http://www.duke.edu/ jgraham/fei.html

Healy, P. 1985. The impact of bonus schemes on the selection of accounting principles. Journal of Accounting and Economics 7, 85-107.

Healy, P. and J. Wahlen. 1999. A review of the earnings management literature and its implications for standard setting. Accounting Horizons, 13, 365-383.

Healy, P. and K. Palepu. 2001. Information asymmetry, corporate disclosure, and the capital markets: A review of the empirical disclosure literature. Journal of Accounting and Economics 31; 405-440

Hodge, F. 2003. Investors' perceptions of earnings quality, auditor independence, and the usefulness of audited financial information. Accounting Horizons (forthcoming).

Hutton, A. 2003. The determinants and consequences of managerial earnings guidance prior to regulation Fair Disclosure. Working paper, Tuck School of Business at Dartmouth. 
Jorion P., 1985. International portfolio diversification with estimation risk, Journal of Business 58, 259-278.

Kamin, Y., and J. Ronen. 1978. The smoothing of income numbers: Some empirical evidence on systematic differences among manager-controlled and owner-controlled firms. Accounting, Organizations and Society 3(2): 141-157.

Klein, R. and V. Bawa. 1976. The effect of estimation risk on optimal portfolio choice, Journal of Financial Economics 3, 215-231.

Kim, O. and R. Verrechhia. 1994. Market liquidity and volume around earnings announcements. Journal of Accounting and Economics 17, 41-68.

Lang, M and R. Lundholm. 1996. Corporate disclosure policy and analyst behavior. The Accounting Review 71, 467-493.

Lev, B. 2001. Intangibles: Management, Measurement, and Reporting. The Brookings Institution.

Lev, B. 2003. Corporate earnings: Facts and fiction, Journal of Economic Perspectives 17, 27-50.

Matsunaga, S. and C. Park. 2001. The effect of missing a quarterly earnings benchmark on the CEO's annual bonus. The Accounting Review 76: 313-332.

Merton, R.C., 1987. A simple model of capital market equilibrium with incomplete information. Journal of Finance 42, 483-510.

Miller, E.M., 1977, Risk, uncertainty, and divergence of opinion. Journal of Finance 32, 1151-1168.

Miller, G., and J. Piotroski. 2000. The role of disclosure for high book-to-market firms. Unpublished working paper, Harvard University.

Nanda, D.J., V. Nagar and P. Wysocki. 2003. Discretionary disclosure and stock-based incentives. Journal of Accounting and Economics 34(1-3): 283-309.

Nelson, M., J. Elliot and R. Tarpley. 2002. Evidence from auditors about managers' and auditors' earnings management decisions. The Accounting Review 77, 175-202.

Nelson, M., J. Elliot and R. Tarpley. 2003. How are earnings managed? Examples from auditors. Accounting Horizons, 17 (Supplement): 17-35.

Noe, C., 1999. Voluntary disclosures and insider transactions. Journal of Accounting and Economics 27, 305-327.

Parfet, W. 2000. Accounting subjectivity and earnings management: A preparer's perspective. Accounting Horizons 14(4): 481-488.

Pastena, V. and J. Ronen. 1979. Some hypotheses on the pattern of management's informal disclosures. Journal of Accounting Research 17(2):550-570.

Ronen, J., and S. Sadan. 1981. Smoothing Income Numbers: Objectives and Implications. Reading, MA: AddisonWesley.

Roychowdhury, S. 2003. Management of earnings through the manipulation of real activities that affect cash flow from operations. Working paper, Sloan School of Management, MIT.

Sengupta, P., 1998. Corporate disclosure quality and the cost of debt. The Accounting Review 73, 459-474.

Shevlin,T. and D. Shackelford. 2001 Empirical tax research in accounting, Journal of Accounting and Economics, 31 (1-3): 321-387.

Sloan. R. 1996. Do stock prices fully reflect information in accruals and cash flows about future earnings? The Accounting Review 71: 289-315.

Skinner, D., 1994. Why firms voluntarily disclose bad news? Journal of Accounting Research 32, 38-61.

Skinner, D., 1997. Earnings disclosures and stockholder lawsuits. Journal of Accounting and Economics 23, 249283. 
Skinner, D., and R. Sloan. 2002. Earnings surprises, growth expectations, and stock returns or don't let an earnings torpedo sink your portfolio. Review of Accounting Studies 7 (2-3): 289-312.

Stein, J. 1989. Efficient capital markets, inefficient firms: A model of myopic corporate behavior. The Quarterly Journal of Economics 104(4): 655-669.

Sudman, Seymour and Norman Bradburn, 1983, Asking Questions: A Practical Guide to Questionnaire Design, San Francisco: Jossey Bass.

Tasker, S. 1998. Bridging the information gap: Quarterly conference calls as a medium for voluntary disclosure. Review of Accounting Studies 3(1): 137-167.

Teoh, S., I. Welch, and T.J. Wong. 1998a. Earnings management and the long--run market performance of initial public offerings. Journal of Finance 53(6): 1935-1974.

Teoh, S., I. Welch, and T.J. Wong. 1998b. Earnings management and the underperformance of seasoned equity offerings. Journal of Financial Economics 50(1): 63-99.

Trahan, E. and L. Gitman. 1995. Bridging the theory-practice gap in corporate finance. A survey of Chief Financial Officers. Quarterly Review of Economics and Finance 35, 73-87.

Trueman, B., 1986. Why do managers voluntarily release earnings forecasts? Journal of Accounting and Economics 8, 53-72.

Verrecchia, R. 2001. Essays in disclosure. Journal of Accounting and Economics 32 (1-3): 97-180

Watts, R., and J. Zimmerman. 1978. Towards a positive theory of the determination of accounting standards. The Accounting Review 53, 112-13.

Watts, R., and J. Zimmerman. 1986. Positive Accounting Theory. Prentice Hall, Englewood Cliffs, NJ.

Watts, R., and J. Zimmerman. 1990. Positive accounting theory: a ten year perspective. The Accounting Review 65, 131-156.

Xia Y. 2001, Learning about predictability: The effects of parameter uncertainty on dynamic asset allocation, Journal of Finance 56, 205-246. 
Table 1

\section{Panel A: Distribution of survey participant characteristics}

\begin{tabular}{|c|c|c|c|}
\hline \multirow[b]{2}{*}{ Ownership } & \multirow[t]{2}{*}{ Percent } & \multirow[b]{2}{*}{ Number of employees } & \multirow[t]{2}{*}{ Percent } \\
\hline & & & \\
\hline Public/NYSE & $51.1 \%$ & $<100$ & $5.2 \%$ \\
\hline Public Nasdaq/Amex & $36.0 \%$ & $100-499$ & $13.6 \%$ \\
\hline \multirow[t]{4}{*}{ Private } & $12.8 \%$ & $500-999$ & $5.5 \%$ \\
\hline & & $1,000-2,499$ & $12.9 \%$ \\
\hline & & 2,500-4,999 & $13.9 \%$ \\
\hline & & $5,000-9,999$ & $13.9 \%$ \\
\hline CEO age & & $>10,000$ & $35.0 \%$ \\
\hline$<=39$ & $2.3 \%$ & & \\
\hline $40-49$ & $25.6 \%$ & & \\
\hline $50-59$ & $49.5 \%$ & Industry & \\
\hline \multirow[t]{4}{*}{$>=60$} & $22.7 \%$ & & \\
\hline & & Retail \& Wholesale & $8.6 \%$ \\
\hline & & Tech [Software/Biotech] & $13.9 \%$ \\
\hline & & Bank/Finance/Insurance & $13.2 \%$ \\
\hline \multirow[t]{2}{*}{ CEO tenure } & & Manufacturing & $30.7 \%$ \\
\hline & & Public Utility & $3.3 \%$ \\
\hline$<4$ yrs & $36.9 \%$ & Transportation/Energy & $5.3 \%$ \\
\hline $4-9$ yrs & $33.0 \%$ & Other & $12.2 \%$ \\
\hline$>=10 \mathrm{yrs}$ & $30.1 \%$ & & \\
\hline
\end{tabular}

\section{CEO education}

College degree

MBA

$33.0 \%$

$36.0 \%$

$12.5 \%$

non-MBA masters

$>$ masters

$15.2 \%$

\section{Insider ownership}

$\begin{array}{ll}<5 \% & 45.2 \% \\ 5-10 \% & 20.3 \% \\ 11-20 \% & 12.1 \% \\ >20 \% & 22.3 \%\end{array}$

\section{Number of analysts}

\section{Revenues}

$<\$ 100$ million

$15.1 \%$

None

$7.8 \%$

$1-5 \quad 39.9 \%$

\$100-499 million

$22.0 \%$

6-10

$21.6 \%$

\$500-999 million

$12.8 \%$

11-15

$14.1 \%$

\$1-4.9 billion

$24.6 \%$

$>\$ 5$ billion

$25.6 \%$

$16.7 \%$

\section{Guidance}

$\begin{array}{lr}\text { 0. None } & 19.3 \% \\ \text { 1. a little } & 18.0 \% \\ \text { 2. } & 8.5 \% \\ \text { 3. moderate } & 32.0 \% \\ \text { 4. } & 13.7 \% \\ \text { 5. a lot } & 8.5 \%\end{array}$

Notes: Frequencies are based on non-missing observations 
Table 1 (continued)

\section{Panel B: Pearson correlation coefficients}

\begin{tabular}{|c|c|c|c|c|c|c|c|c|c|c|c|c|c|c|c|c|}
\hline & Leverage & Profit & PE ratio & $\begin{array}{r}\text { Sales } \\
\text { growth }\end{array}$ & $\begin{array}{r}\text { Stock } \\
\text { price }\end{array}$ & Firm age & Ownership & CEO age & EO tenure & $\begin{array}{c}\text { CEO } \\
\text { education }\end{array}$ & Revenues & $\begin{array}{l}\text { Number of } \\
\text { employees }\end{array}$ & Industry & Insider & $\begin{array}{r}\text { Number of } \\
\text { analysts }\end{array}$ & Guidance \\
\hline Profit & -0.028 & 1.000 & & & & & & & & & & & & & & \\
\hline PE ratio & $-0.222^{* * *}$ & 0.008 & 1.000 & & & & & & & & & & & & & \\
\hline Sales growth & 0.098 & $0.167^{* * *}$ & -0.080 & 1.000 & & & & & & & & & & & & \\
\hline Stock price & -0.018 & $0.234^{* * *}$ & 0.023 & 0.096 & 1.000 & & & & & & & & & & & \\
\hline Firm age & 0.100 & $0.199 * * *$ & -0.107 & -0.062 & $0.155^{* * *}$ & 1.000 & & & & & & & & & & \\
\hline Ownership & $-0.157 * * *$ & $-0.239 * * *$ & 0.012 & 0.039 & $-0.174 * * *$ & $-0.379 * * *$ & 1.000 & & & & & & & & & \\
\hline CEO age & 0.064 & $0.171^{* * *}$ & 0.056 & 0.024 & 0.091 & $0.173 * * *$ & $-0.17 * * *$ & 1.000 & & & & & & & & \\
\hline CEO tenure & 0.030 & $0.163^{* * *}$ & -0.016 & $0.119 * *$ & 0.076 & $-0.097 *$ & 0.062 & $0.347^{* * *}$ & 1.000 & & & & & & & \\
\hline EO education & 0.036 & -0.037 & 0.038 & 0.073 & 0.026 & -0.029 & -0.023 & -0.030 & -0.068 & 1.000 & & & & & & \\
\hline Revenues & 0.071 & $0.339 * * *$ & 0.040 & 0.026 & $0.252^{* * *}$ & $0.366^{* * *}$ & $-0.591^{* * *}$ & $0.153 * * *$ & -0.044 & -0.040 & 1.000 & & & & & \\
\hline $\begin{array}{l}\text { Number of } \\
\text { employees }\end{array}$ & 0.083 & $0.361^{* * *}$ & 0.037 & 0.013 & $0.262 * * *$ & $0.392 * * *$ & $-0.514 * * *$ & $0.182 * * *$ & -0.006 & -0.054 & $0.859 * * *$ & 1.000 & & & & \\
\hline Industry & $0.107^{*}$ & $0.1^{*}$ & -0.008 & -0.036 & 0.014 & 0.086 & $-0.154^{* * *}$ & 0.024 & -0.007 & 0.058 & $0.118^{* *}$ & 0.054 & 1.000 & & & \\
\hline Insider & -0.057 & 0.013 & $0.118 *$ & 0.030 & 0.007 & $-0.254 * * *$ & $0.277 * * *$ & -0.059 & $0.211^{* * *}$ & $-0.099 *$ & $-0.318^{* * *}$ & $-0.224 * * *$ & -0.006 & 1.000 & & \\
\hline Analysts & -0.008 & $0.258^{* * *}$ & $0.209^{* * *}$ & $0.113^{*}$ & $0.181^{* * *}$ & 0.092 & $-0.338^{* * *}$ & 0.075 & -0.025 & 0.084 & $0.639 * * *$ & $0.563 * * *$ & 0.049 & $-0.243 * * *$ & 1.000 & \\
\hline Guidance & -0.040 & $0.134 * *$ & 0.054 & $0.231 * * *$ & 0.070 & 0.074 & $-0.145^{* *}$ & -0.014 & 0.010 & $0.146^{* *}$ & $0.374 * * *$ & $0.333^{* * *}$ & $0.12 * *$ & $-0.207 * * *$ & $0.437 * * *$ & 1.000 \\
\hline
\end{tabular}


Table 1 (continued)

The table reports summary statistics on the representativeness of both the interviewed (Panel C) and surveyed firms (Panel D) relative to the universe of firms listed on NYSE, AMEX and NASDAQ and with CRSP share codes of 10 and 11.

Comparison is based on the following variables: Sales, Debt-to-assets, Dividend yield, Earnings per share, Credit rating, Book-to-market, Price-earnings ratio. Since companies report their firm characterstics we are able to compare those with Compustat. The information for the universe of firms is obtained from Compustat. For each such variable, we identify all candidate firms listed on the three major exchanges with valid data on Compustat and share codes 10 and 11 on CRSP as of November 2003, the time at which we conducted the survey and interviewed most of the 20 firms. We then sort all firms with valid data into quintiles and record the corresponding breakpoints. For each qunitile, we then report in Panel C (Panel D) the percentage of interviewed (surveyed) firms that are allocated into these five sorts. The reported percentages can then be compared to the benchmark $20 \%$ and thus allow us to infer whether our samples are representative and on which dimensions.

Panel C: Representativeness of 20 interviewed firms

\begin{tabular}{|c|c|c|c|c|c|c|c|c|}
\hline \multirow{2}{*}{ Variable } & & \multirow{2}{*}{$\begin{array}{l}\text { Sample } \\
\text { average }\end{array}$} & \multirow{2}{*}{$\begin{array}{l}\text { Sample } \\
\text { median }\end{array}$} & \multicolumn{5}{|c|}{ Compustat breakpoint quintiles } \\
\hline & & & & 1 & 2 & 3 & 4 & 5 \\
\hline \multirow{3}{*}{ Sales } & Universe avg. & & & 10.58 & 47.22 & 153.43 & 547.21 & 7596.30 \\
\hline & Sample avg. & 47601.16 & 23591.00 & N.A. & N.A. & 123.30 & N.A. & 53186.79 \\
\hline & Sample \% & & & $0.00 \%$ & $0.00 \%$ & $10.53 \%$ & $0.00 \%$ & $89.47 \%$ \\
\hline \multirow{3}{*}{$\begin{array}{l}\text { Debt } \\
\text { to } \\
\text { assets }\end{array}$} & Universe avg. & & & 0.00 & 0.01 & 0.09 & 0.22 & 0.49 \\
\hline & Sample avg. & 0.22 & 0.23 & 0.00 & 0.00 & 0.10 & 0.24 & 0.45 \\
\hline & Sample \% & & & $5.26 \%$ & $5.26 \%$ & $26.32 \%$ & $42.11 \%$ & $21.05 \%$ \\
\hline \multirow{3}{*}{$\begin{array}{l}\text { Dividend } \\
\text { yield }\end{array}$} & Universe avg. & & & 0.00 & 0.00 & 0.00 & 0.00 & 0.19 \\
\hline & Sample avg. & 0.02 & 0.02 & N.A. & N.A. & 0.00 & 0.01 & 0.04 \\
\hline & Sample \% & & & $0.00 \%$ & $0.00 \%$ & $26.32 \%$ & $26.32 \%$ & $47.37 \%$ \\
\hline \multirow{3}{*}{ EPS } & Universe avg. & & & -3.11 & -0.30 & 0.31 & 1.09 & 5.57 \\
\hline & Sample avg. & 1.18 & 1.96 & -5.00 & -0.04 & N.A. & 1.33 & 2.92 \\
\hline & Sample \% & & & $15.79 \%$ & $5.26 \%$ & $0.00 \%$ & $21.05 \%$ & $57.89 \%$ \\
\hline \multirow{3}{*}{$\begin{array}{l}\text { Credit } \\
\text { rating }\end{array}$} & Universe avg. & & & 18.1(B-) & 14.7(BB-) & 12.4(BBB- & 10.4(BBB+) & $7.4(\mathrm{~A}+)$ \\
\hline & Sample avg. & 8.7(A-) & $7(\mathrm{~A}+)$ & 27(D) & 15(BB-) & 14(BB) & 11(BBB) & 5.8(AA-) \\
\hline & Sample \% & & & $5.88 \%$ & $5.88 \%$ & $5.88 \%$ & $11.76 \%$ & $70.59 \%$ \\
\hline \multirow{3}{*}{$\begin{array}{l}\text { Book } \\
\text { to } \\
\text { market }\end{array}$} & Universe avg. & & & -23.57 & 0.44 & 0.67 & 0.97 & 4.11 \\
\hline & Sample avg. & 0.50 & 0.26 & 0.17 & 0.41 & 0.65 & 1.14 & 3.91 \\
\hline & Sample \% & & & $57.89 \%$ & $26.32 \%$ & $5.26 \%$ & $5.26 \%$ & $5.26 \%$ \\
\hline \multirow{3}{*}{$\begin{array}{c}\text { Price } \\
\text { to } \\
\text { earnings }\end{array}$} & Universe avg. & & & -36.32 & -0.98 & 9.54 & 15.84 & 58.46 \\
\hline & Sample avg. & 7.20 & 17.50 & -78.15 & -0.67 & 10.10 & 16.72 & 25.79 \\
\hline & Sample \% & & & $10.53 \%$ & $10.53 \%$ & $15.79 \%$ & $26.32 \%$ & $36.84 \%$ \\
\hline \multirow[t]{3}{*}{$\mathrm{PE}(>0)$} & Universe avg. & & & 7.64 & 12.31 & 15.64 & 21.43 & 81.71 \\
\hline & Sample avg. & 19.63 & 18.34 & 7.92 & 11.19 & 15.81 & 21.88 & 31.78 \\
\hline & Sample \% & & & $6.67 \%$ & $13.33 \%$ & $20.00 \%$ & $46.67 \%$ & $13.33 \%$ \\
\hline
\end{tabular}


Table 1 (continued)

Panel D: Representativeness of surveyed public firms

\begin{tabular}{|c|c|c|c|c|c|c|c|c|}
\hline & \multirow{2}{*}{ Variable } & \multirow{2}{*}{$\begin{array}{l}\text { Sample } \\
\text { average }\end{array}$} & \multirow{2}{*}{$\begin{array}{l}\text { Sample } \\
\text { median }\end{array}$} & \multicolumn{5}{|c|}{ Compustat breakpoint quintiles } \\
\hline & & & & 1 & 2 & 3 & 4 & 5 \\
\hline \multirow{3}{*}{ Sales } & Universe avg. & & & 10.58 & 47.22 & 153.43 & 547.21 & $\overline{7596.30}$ \\
\hline & Sample avg. & 2185.74 & 3000.00 & N.A. & 50.00 & N.A. & 465.57 & 4019.61 \\
\hline & Sample \% & & & $0.00 \%$ & $15.08 \%$ & $0.00 \%$ & $34.75 \%$ & $50.16 \%$ \\
\hline \multirow{3}{*}{$\begin{array}{l}\text { Debt } \\
\text { to } \\
\text { assets }\end{array}$} & Universe avg. & & & 0.00 & 0.01 & 0.09 & 0.22 & 0.49 \\
\hline & Sample avg. & 0.31 & 0.28 & 0.00 & 0.03 & 0.11 & 0.25 & 0.55 \\
\hline & Sample \% & & & $15.38 \%$ & $4.03 \%$ & $11.72 \%$ & $27.84 \%$ & $41.03 \%$ \\
\hline \multirow{3}{*}{$\begin{array}{c}\text { Dividend } \\
\text { yield }\end{array}$} & Universe avg. & & & 0.000 & 0.000 & 0.000 & 0.005 & 0.193 \\
\hline & Sample avg. & 0.012 & 0.000 & N.A. & N.A. & 0.000 & 0.010 & 0.037 \\
\hline & Sample \% & & & $0.00 \%$ & $0.00 \%$ & $55.17 \%$ & $17.24 \%$ & $27.59 \%$ \\
\hline \multirow{3}{*}{ EPS } & Universe avg. & & & -3.11 & -0.30 & 0.31 & 1.09 & 5.57 \\
\hline & Sample avg. & 2.81 & 1.56 & N.A. & 0.00 & 0.43 & 1.14 & 4.60 \\
\hline & Sample \% & & & $0.00 \%$ & $0.48 \%$ & $12.92 \%$ & $35.41 \%$ & $51.20 \%$ \\
\hline \multirow{3}{*}{$\begin{array}{l}\text { Credit } \\
\text { rating }\end{array}$} & Universe avg. & & & 18.1(B-) & 14.7(BB-) & 12.4(BBB-) & $10.4(\mathrm{BBB}+)$ & $7.4(\mathrm{~A}+)$ \\
\hline & Sample avg. & 9.8(BBB+) & $10(\mathrm{BBB}+)$ & 17.8(B-) & $15.2(\mathrm{BB}-)$ & $12.9(\mathrm{BB}+)$ & 10.5(BBB) & 5.9(AA-) \\
\hline & Sample \% & & & $6.09 \%$ & $5.58 \%$ & $23.35 \%$ & $22.34 \%$ & $42.64 \%$ \\
\hline \multirow{3}{*}{$\begin{array}{l}\text { Book } \\
\text { to } \\
\text { market }\end{array}$} & Universe avg. & & & -23.57 & 0.44 & 0.67 & 0.97 & 4.11 \\
\hline & Sample avg. & 0.74 & 0.60 & 0.07 & 0.44 & 0.68 & 0.96 & 2.17 \\
\hline & Sample \% & & & $22.81 \%$ & $23.68 \%$ & $21.93 \%$ & $17.54 \%$ & $14.04 \%$ \\
\hline \multirow{3}{*}{$\begin{array}{c}\text { Price } \\
\text { to } \\
\text { earnings }\end{array}$} & Universe avg. & & & -36.32 & -0.98 & 9.54 & 15.84 & 58.46 \\
\hline & Sample avg. & 18.55 & 17.00 & N.A. & 0.75 & 9.85 & 15.81 & 28.23 \\
\hline & Sample \% & & & $0.00 \%$ & $0.48 \%$ & $25.24 \%$ & $39.52 \%$ & $34.76 \%$ \\
\hline \multirow{3}{*}{$\operatorname{PE}(>0)$} & Universe avg. & & & 7.64 & 12.31 & 15.64 & 21.43 & 81.71 \\
\hline & Sample avg. & 18.55 & 17.00 & 7.81 & 12.29 & 15.38 & 20.94 & 37.02 \\
\hline & Sample \% & & & $13.81 \%$ & $18.57 \%$ & $21.43 \%$ & $32.38 \%$ & $13.81 \%$ \\
\hline
\end{tabular}

1) Sales, is based on Data 12; Debt-to-asset, is based on Data 9-long term debt divided by Data6-total assets; 3) Dividend yield, is the ratio of Data26 divided by the firm's stock price, Data24; 4) Earnings per share, denoted, EPS, is Data58-EPS (basic) excluding extraordinary items; 5) Credit rating, is Compustat variable SPDRC: S\&P long term domestic issuer credit rating; 6) Book to market, denoted BM, is total stockholders' equity, Data216, divided by size, where size is computed as the product of price Data24, and common shares outstanding, Data25; 7) Price-earnings ratio is firm's stock price, Data24 divided by EPS, Data58-EPS (basic excluding extra-ordinary items. 
Table 2

Survey responses to the question: Rank the three most important performance measures reported to outsiders

In panel $\mathrm{A}$, points are assigned as follow: 3 points for a \#1 ranking; 2 points for a \#2 ranking; 1 point for a \#3 ranking.

Panel B presents a comparison of the percent of respondents indicating they agree or strongly agree with each statement when the sample is split on various firm characteristics. These characteristics are Size, where large indicates revenues exceeding $\$ 1$ billion; P/E, where high indicates a Price/Earnings ratio greater than 17 , the median for all public firms surveyed; Sales Growth, where high indicates average sales growth over the last 3 years greater than $5 \%$, the median for all public firms surveyed; D/A, where high indicates a debt-to-total assets ratio exceeding 0.25; Credit Rating, where high indicates above investment grade; Tech Industry, an indicator for whether a firm is in a high technology industry; Exchange, in which NYSE firms are compared to AMEX/Nasdaq listed firms; CEO age, where mature indicates at least 60 years old; Ownership, where public firms are compared to private firms; Profitable, an indicator for whether or not a firm reported a profit last year; Firm Age, where old indicates firms more than 36 years old, the median for all public firms surveyed; Guidance, where low refers to those firms that indicated they provide no or little earnings guidance; Number of Analysts, where few refers to those firms that indicated that 5 or fewer analysts currently follow their stock; and CEO education, where firms for which the CEO has an MBA are compared to all others. The sample for all comparisons in Panel B is all public firms surveyed, with the exception of the Ownership column, which uses all firms surveyed. $* * * * *$, and * denote a statistically significant difference across groups at the $1 \%, 5 \%$, and $10 \%$ levels, respectively.

\section{Panel A: Unconditional averages}

\begin{tabular}{lccccc}
\hline \multicolumn{1}{c}{ Measure } & \#1 Rankings & \#2 Rankings & \#3 Rankings & Total points & $\begin{array}{c}\text { Average } \\
\text { points }\end{array}$ \\
\hline Earnings & 159 & 67 & 31 & 642 & 2.10 \\
Revenues & 36 & 97 & 75 & 377 & 1.24 \\
Cash flows from operations & 36 & 72 & 93 & 345 & 1.13 \\
Free cash flows & 30 & 41 & 42 & 214 & 0.70 \\
Pro forma earnings & 38 & 10 & 24 & 158 & 0.52 \\
Other & 7 & 13 & 28 & 75 & 0.25 \\
EVA & 2 & 4 & 5 & 19 & 0.06 \\
\hline
\end{tabular}

\section{Panel B: Conditional average}

\begin{tabular}{|c|c|c|c|c|c|c|c|c|c|c|c|c|c|c|c|c|c|c|}
\hline \multirow[t]{2}{*}{ Measure } & \multirow[t]{2}{*}{$\begin{array}{c}\text { Average } \\
\text { points }\end{array}$} & \multirow[t]{2}{*}{$\begin{array}{c}\text { Number of } \\
\text { observations }\end{array}$} & \multicolumn{2}{|c|}{ Size } & \multicolumn{2}{|c|}{$P / E$} & \multicolumn{2}{|c|}{ Sales growth } & \multicolumn{2}{|c|}{ Debt to assets } & \multicolumn{2}{|c|}{ Credit rating } & \multicolumn{2}{|c|}{ Tech industry } & \multicolumn{2}{|c|}{ Insider } & \multicolumn{2}{|c|}{ Exchange } \\
\hline & & & Small & Large & Low & High & Low & High & Low & High & Low & High & Other & Tech & Low & High & $\begin{array}{c}\text { NASDAQ/ } \\
\text { Amex }\end{array}$ & NYSE \\
\hline Earnings & 2.10 & 305 & 2.06 & 2.13 & 2.38 & $2.10 *$ & 2.14 & 2.11 & 2.20 & 2.01 & 2.12 & 2.16 & 2.14 & 1.88 & 2.17 & 2.06 & 2.05 & 2.15 \\
\hline Revenues & 1.24 & 305 & 1.37 & $1.10 * *$ & 1.09 & $1.37 *$ & 1.17 & $1.39 *$ & 1.34 & $1.11 *$ & 0.96 & $1.27 * *$ & 1.21 & 1.46 & 1.12 & $1.34 *$ & 1.43 & $1.10 * * *$ \\
\hline Cash flows from operations & 1.13 & 305 & 1.18 & 1.08 & 1.08 & 1.07 & 1.14 & 1.09 & 1.11 & 1.12 & 1.23 & 1.02 & 1.14 & 1.05 & 1.08 & 1.17 & 1.21 & 1.07 \\
\hline Free cash flows & 0.70 & 305 & 0.64 & 0.75 & 0.71 & 0.75 & 0.76 & 0.63 & 0.67 & 0.80 & 0.89 & $0.62 *$ & 0.69 & 0.73 & 0.66 & 0.74 & 0.62 & 0.76 \\
\hline Pro forma earnings & 0.52 & 305 & 0.50 & 0.56 & 0.40 & 0.52 & 0.49 & 0.56 & 0.42 & 0.60 & 0.44 & 0.55 & 0.49 & 0.73 & 0.59 & 0.44 & 0.45 & 0.57 \\
\hline Other & 0.25 & 305 & 0.23 & 0.28 & 0.26 & 0.16 & 0.24 & 0.20 & 0.26 & 0.26 & 0.35 & 0.26 & 0.27 & $0.07 *$ & 0.29 & 0.22 & 0.26 & 0.24 \\
\hline EVA & 0.06 & 305 & 0.05 & 0.08 & 0.06 & 0.04 & 0.07 & 0.04 & 0.01 & $0.09 * *$ & 0.03 & 0.11 & 0.06 & 0.07 & 0.08 & 0.04 & 0.02 & 0.09 \\
\hline
\end{tabular}

\begin{tabular}{|c|c|c|c|c|c|c|c|c|c|c|c|c|c|c|c|c|}
\hline \multirow[t]{2}{*}{ Measure } & \multirow[t]{2}{*}{$\begin{array}{c}\text { Average } \\
\text { points }\end{array}$} & \multirow[t]{2}{*}{$\begin{array}{l}\text { Number of } \\
\text { observations }\end{array}$} & \multicolumn{2}{|c|}{ CEO age } & \multicolumn{2}{|c|}{ Ownership } & \multicolumn{2}{|c|}{ Profitable } & \multicolumn{2}{|c|}{ Firm age } & \multicolumn{2}{|c|}{ Guidance } & \multicolumn{2}{|c|}{$\begin{array}{c}\text { Number of } \\
\text { analysts }\end{array}$} & \multicolumn{2}{|c|}{ CEO education } \\
\hline & & & Young & Mature & Private & Public & No & Yes & Young & Old & Little & Much & Few & Many & MBA & Other \\
\hline Earnings & 2.10 & 305 & 2.01 & $2.47^{* * *}$ & 1.84 & 2.10 & 1.66 & $2.26 * * *$ & 1.96 & $2.25 * *$ & 2.20 & 2.03 & 2.15 & 2.05 & 2.10 & 2.11 \\
\hline Revenues & 1.24 & 305 & 1.23 & 1.24 & 1.02 & 1.24 & 1.29 & 1.22 & 1.30 & 1.19 & 1.14 & 1.26 & 1.31 & 1.17 & 1.18 & 1.27 \\
\hline Cash flows from operations & 1.13 & 305 & 1.19 & $0.93 *$ & 1.71 & $1.13 * * *$ & 1.16 & 1.11 & 1.25 & $0.99 * *$ & 1.35 & $1.00 * * *$ & 1.21 & 1.03 & 1.08 & 1.15 \\
\hline Free cash flows & 0.70 & 305 & 0.68 & 0.81 & 0.80 & 0.70 & 0.71 & 0.70 & 0.71 & 0.73 & 0.80 & 0.67 & 0.72 & 0.71 & 0.75 & 0.71 \\
\hline Pro forma earnings & 0.52 & 305 & 0.60 & $0.23 * * *$ & 0.20 & $0.52 * *$ & 0.82 & $0.42 * * *$ & 0.49 & 0.55 & 0.23 & $0.70^{* * *}$ & 0.36 & $0.66 * *$ & 0.58 & 0.48 \\
\hline Other & 0.25 & 305 & 0.24 & 0.23 & 0.22 & 0.25 & 0.32 & 0.22 & 0.25 & 0.22 & 0.21 & 0.27 & 0.25 & 0.25 & 0.25 & 0.23 \\
\hline EVA & 0.06 & 305 & 0.05 & 0.10 & 0.16 & 0.06 & 0.05 & 0.07 & 0.05 & 0.05 & 0.07 & 0.06 & 0.03 & 0.09 & 0.07 & 0.06 \\
\hline
\end{tabular}




\section{Table 3}

\section{Survey responses to the question: How important are the following earnings benchmarks to your company when you report a quarterly earnings number?}

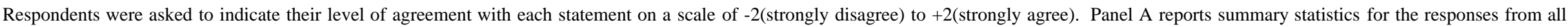

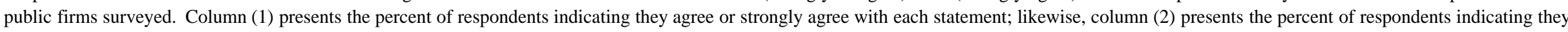

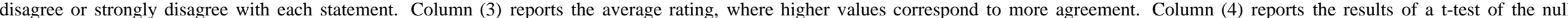

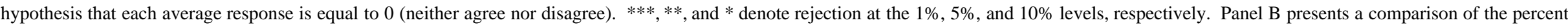

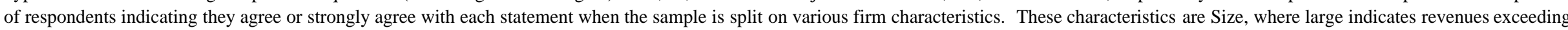

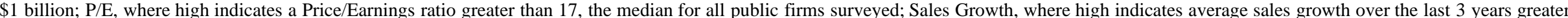

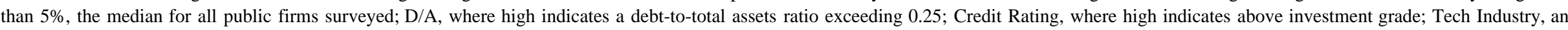

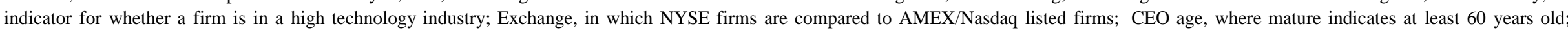

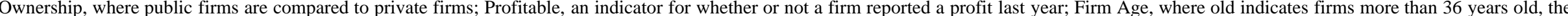

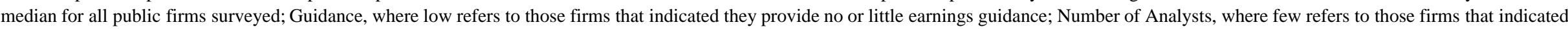

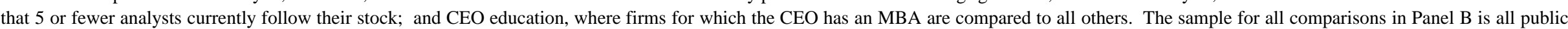

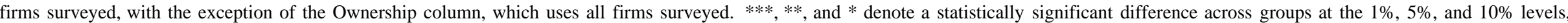
respectively.

\section{Panel A: Unconditional averages}

\begin{tabular}{|c|c|c|c|c|c|}
\hline Question & & $\begin{array}{c}\text { \% agree or strongly } \\
\text { agree }\end{array}$ & $\begin{array}{c}\text { \% disagree or } \\
\text { strongly disagree }\end{array}$ & Average rating & $\begin{array}{c}\boldsymbol{H}_{0} \text { : Average } \\
\text { rating }=0\end{array}$ \\
\hline$(1)$ & Same quarter last year EPS & $84.3 \%$ & $6.9 \%$ & 1.25 & $* * *$ \\
\hline$(1)$ & Analyst consensus forecast of EPS for current quarter & $68.8 \%$ & $13.2 \%$ & 0.82 & $* * *$ \\
\hline$(3)$ & Reporting a profit (i.e. EPS $>0$ ) & $65.0 \%$ & $12.1 \%$ & 0.83 & $* * *$ \\
\hline$(4)$ & Previous quarter EPS & $54.6 \%$ & $20.2 \%$ & 0.47 & $* * *$ \\
\hline
\end{tabular}

\section{Panel B: Conditional averages}

\begin{tabular}{|c|c|c|c|c|c|c|c|c|c|c|c|c|c|c|c|c|c|c|}
\hline \multirow[t]{2}{*}{ Question } & \multirow{2}{*}{$\begin{array}{c}\% \text { agree or } \\
\text { strongly } \\
\text { agree }\end{array}$} & \multirow[t]{2}{*}{ Obs. } & \multicolumn{2}{|r|}{ Size } & \multicolumn{2}{|c|}{$P / E$} & \multicolumn{2}{|c|}{ Sales growth } & \multicolumn{2}{|c|}{ Debt to assets } & \multicolumn{2}{|c|}{ Credit rating } & \multicolumn{2}{|c|}{ Tech industry } & \multicolumn{2}{|c|}{ Insider } & \multicolumn{2}{|c|}{ Exchange } \\
\hline & & & Small & Large & Low & High & Low & High & Low & High & Low & High & Other & Tech & Low & High & $\begin{array}{c}\text { NASDAQ/ } \\
\text { Amex }\end{array}$ & NYSE \\
\hline (1) & 84.3 & 306 & 79.9 & $88.7 * *$ & 91.2 & 92.8 & 86.5 & 82.8 & 83.2 & 86.5 & 84.9 & 87.6 & 85.2 & 78.0 & 81.6 & 86.5 & 78.0 & $88.8 * *$ \\
\hline (2) & 68.8 & 304 & 58.1 & $79.2 * * *$ & 65.5 & 75.3 & 63.9 & $73.4 *$ & 59.5 & $76.6 * * *$ & 67.7 & 73.4 & 67.7 & 68.3 & 72.6 & 64.8 & 55.6 & $78.1 * * *$ \\
\hline (3) & 65.0 & 306 & 67.8 & 62.0 & 65.5 & 60.8 & 64.9 & 68.0 & 67.9 & 60.3 & 61.3 & 66.7 & 64.5 & 68.3 & 64.7 & 66.3 & 66.9 & 63.7 \\
\hline (4) & 54.6 & 302 & 58.9 & 50.3 & 42.0 & $61.1 * * *$ & 53.1 & 53.5 & 56.9 & 49.6 & 48.9 & 56.7 & 50.4 & $78.0 * * *$ & 52.2 & 56.5 & 60.8 & $50.3 *$ \\
\hline
\end{tabular}

\begin{tabular}{|c|c|c|c|c|c|c|c|c|c|c|c|c|c|c|c|c|}
\hline \multirow[t]{2}{*}{ Question } & \multirow[t]{2}{*}{$\begin{array}{c}\text { \% agree or } \\
\text { strongly } \\
\text { agree }\end{array}$} & \multirow[t]{2}{*}{ Obs. } & \multicolumn{2}{|c|}{ CEO age } & \multicolumn{2}{|c|}{ Ownership } & \multicolumn{2}{|c|}{ Profitable } & \multicolumn{2}{|c|}{ Firm age } & \multicolumn{2}{|c|}{ Guidance } & \multicolumn{2}{|c|}{$\begin{array}{c}\text { Number of } \\
\text { analysts }\end{array}$} & \multicolumn{2}{|c|}{ CEO education } \\
\hline & & & Young & Mature & Private & Public & No & Yes & Young & Old & Little & Much & Few & Many & MBA & Other \\
\hline (1) & 84.3 & 306 & 83.7 & 87.1 & 60.5 & $84.3 * * *$ & 69.7 & $89.9 * * *$ & 78.1 & $90.7 * * *$ & 85.8 & 83.4 & 83.2 & 85.4 & 84.9 & 84.8 \\
\hline (2) & 68.8 & 304 & 67.1 & 72.9 & 14.3 & $68.8 * * *$ & 59.5 & $72.4 * *$ & 65.3 & 70.7 & 53.1 & $78.9 * * *$ & 54.2 & $82.1 * * *$ & 63.2 & 72.0 \\
\hline (3) & 65.0 & 306 & 61.8 & $75.7 * *$ & 72.1 & 65.0 & 69.7 & 63.6 & 66.4 & 64.0 & 63.7 & 65.8 & 63.6 & 66.9 & 54.7 & $71.7 * * *$ \\
\hline (4) & 54.6 & 302 & 56.3 & 50.0 & 37.2 & $54.6 * *$ & 66.7 & $51.1 * *$ & 58.6 & $49.0 *$ & 48.2 & 57.0 & 47.5 & $60.0 * *$ & 57.3 & 54.7 \\
\hline
\end{tabular}


Table 4

Survey responses to the question: Do these statements describe why your company tries to meet earnings benchmarks?

See Table 3 header for table and variable descriptions.

\begin{tabular}{|c|c|c|c|c|c|}
\hline Question & Meeting earnings benchmarks helps... & $\begin{array}{c}\text { \% agree or strongly } \\
\text { agree }\end{array}$ & $\begin{array}{c}\text { \% disagree or } \\
\text { strongly disagree }\end{array}$ & Average rating & $\begin{array}{c}\boldsymbol{H}_{0} \text { : Average } \\
\text { rating }=0\end{array}$ \\
\hline (1) & us build credibility with the capital market & $86.3 \%$ & $3.9 \%$ & 1.17 & $* * *$ \\
\hline (2) & us maintain or increase our stock price & $82.2 \%$ & $3.6 \%$ & 1.06 & $* * *$ \\
\hline (3) & the external reputation of our management team & $77.4 \%$ & $3.6 \%$ & 0.95 & $* * *$ \\
\hline (4) & us convey our future growth prospects to investors & $74.1 \%$ & $5.9 \%$ & 0.90 & $* * *$ \\
\hline (5) & us maintain or reduce stock price volatility & $66.6 \%$ & $6.2 \%$ & 0.74 & $* * *$ \\
\hline (6) & us assure customers and suppliers that our business is stable & $58.5 \%$ & $16.3 \%$ & 0.50 & $* * *$ \\
\hline (7) & our employees achieve bonuses & $40.1 \%$ & $30.3 \%$ & 0.06 & \\
\hline (8) & us achieve or preserve a desired credit rating & $39.5 \%$ & $28.8 \%$ & 0.07 & \\
\hline (9) & us avoid violating debt-covenants & $26.5 \%$ & $41.5 \%$ & -0.28 & $* * *$ \\
\hline
\end{tabular}

Panel B: Conditional averages

\begin{tabular}{|c|c|c|c|c|c|c|c|c|c|c|c|c|c|c|c|c|c|c|}
\hline \multirow[t]{2}{*}{ Question } & \multirow{2}{*}{$\begin{array}{c}\% \text { agree or } \\
\text { strongly } \\
\text { agree }\end{array}$} & \multirow[t]{2}{*}{ Obs. } & \multicolumn{2}{|c|}{ Size } & \multicolumn{2}{|c|}{$P / E$} & \multicolumn{2}{|c|}{ Sales growth } & \multicolumn{2}{|c|}{ Debt to assets } & \multicolumn{2}{|c|}{ Credit rating } & \multicolumn{2}{|c|}{ Tech industry } & \multicolumn{2}{|c|}{ Insider } & \multicolumn{2}{|c|}{ Exchange } \\
\hline & & & Small & Large & Low & High & Low & High & Low & High & Low & High & Other & Tech & Low & High & $\begin{array}{l}\text { NASDAQ/ } \\
\text { Amex }\end{array}$ & NYSE \\
\hline (1) & 86.3 & 306 & 84.5 & 88.7 & 86.2 & 82.5 & 84.2 & 87.3 & 82.2 & 88.5 & 83.7 & 86.6 & 85.2 & $95.0 * *$ & 87.5 & 84.7 & 81.1 & $89.9 * *$ \\
\hline (2) & 82.2 & 304 & 78.8 & 85.4 & 80.9 & 80.0 & 79.5 & 83.2 & 75.0 & $85.6 * *$ & 80.4 & 84.1 & 82.0 & 82.5 & 82.2 & 82.2 & 76.8 & $86.0 * *$ \\
\hline (3) & 77.4 & 305 & 77.0 & 78.0 & 75.5 & 75.3 & 74.0 & 78.6 & 72.3 & 79.0 & 78.3 & 74.0 & 75.0 & $87.5 * *$ & 72.6 & 80.5 & 78.6 & 76.5 \\
\hline (4) & 74.1 & 305 & 71.6 & 76.0 & 68.2 & $85.6 * * *$ & 71.2 & 77.0 & 69.2 & 77.5 & 65.2 & $78.0 * *$ & 72.7 & 77.5 & 73.3 & 74.4 & 69.0 & $77.7 *$ \\
\hline (5) & 66.6 & 305 & 61.5 & $70.7 *$ & 61.8 & 68.0 & 67.8 & 64.3 & 66.2 & 64.5 & 60.9 & 67.7 & 65.6 & 72.5 & 66.7 & 65.9 & 61.1 & $70.4 *$ \\
\hline (6) & 58.5 & 306 & 63.8 & $52.7 *$ & 52.7 & 56.7 & 59.6 & 57.1 & 62.3 & $52.2 *$ & 58.7 & 56.7 & 54.3 & $82.9 * * *$ & 51.9 & $63.4 * *$ & 63.8 & 54.7 \\
\hline (7) & 40.1 & 307 & 40.3 & 39.7 & 40.0 & 41.2 & 38.1 & 40.5 & 41.5 & 40.3 & 31.5 & 40.6 & 40.1 & 41.5 & 32.4 & $47.0 * * *$ & 43.3 & 37.8 \\
\hline (8) & 39.5 & 306 & 27.0 & $51.7 * * *$ & 34.5 & 39.2 & 37.4 & 40.5 & 30.0 & $43.9 * *$ & 33.7 & $48.4 * *$ & 42.8 & $20.0 * * *$ & 40.4 & 38.4 & 25.4 & $49.4 * * *$ \\
\hline (9) & 26.5 & 306 & 29.1 & 23.8 & 25.5 & 21.6 & 27.2 & 23.8 & 21.5 & $30.9 *$ & 23.9 & 22.7 & 26.8 & 22.5 & 21.3 & $30.5 *$ & 23.8 & 28.3 \\
\hline
\end{tabular}

\begin{tabular}{|c|c|c|c|c|c|c|c|c|c|c|c|c|c|c|c|c|}
\hline \multirow[t]{2}{*}{ Question } & \multirow[t]{2}{*}{$\begin{array}{c}\text { \% agree or } \\
\text { strongly } \\
\text { agree }\end{array}$} & \multirow[t]{2}{*}{ Obs. } & \multicolumn{2}{|c|}{ CEO age } & \multicolumn{2}{|c|}{ Ownership } & \multicolumn{2}{|c|}{ Profitable } & \multicolumn{2}{|c|}{ Firm age } & \multicolumn{2}{|c|}{ Guidance } & \multicolumn{2}{|c|}{$\begin{array}{c}\text { Number of } \\
\text { analysts }\end{array}$} & \multicolumn{2}{|c|}{ CEO education } \\
\hline & & & Young & Mature & Private & Public & No & Yes & Young & Old & Little & Much & Few & Many & MBA & Other \\
\hline (1) & 86.3 & 306 & 87.2 & 82.4 & 78.3 & 86.3 & 92.0 & $84.4 *$ & 86.0 & 86.5 & 75.9 & $92.0 * * *$ & 81.7 & $89.9 * *$ & 84.3 & 87.4 \\
\hline (2) & 82.2 & 304 & 80.8 & 88.1 & 39.1 & $82.2 * * *$ & 84.9 & 80.8 & 83.1 & 79.7 & 74.1 & $86.6 * * *$ & 78.9 & 84.7 & 79.6 & 83.6 \\
\hline (3) & 77.4 & 305 & 76.9 & 79.4 & 71.7 & 77.4 & 80.8 & 75.6 & 78.5 & 74.1 & 71.7 & $80.7 *$ & 74.1 & 79.6 & 77.6 & 77.0 \\
\hline (4) & 74.1 & 305 & 75.6 & 67.6 & 56.5 & 74.1 ** & 64.4 & $77.3 * *$ & 74.3 & 74.1 & 69.0 & 77.5 & 69.9 & $78.3 *$ & 68.2 & 77.0 \\
\hline (5) & 66.6 & 305 & 66.2 & 67.6 & 23.9 & $66.6 * * *$ & 68.5 & 65.8 & 62.5 & 70.1 & 57.5 & $72.2 * * *$ & 59.4 & $72.6 * *$ & 61.7 & 69.6 \\
\hline (6) & 58.5 & 306 & 57.0 & 63.2 & 67.4 & 58.5 & 71.6 & $54.7 * * *$ & 64.6 & $53.7 *$ & 56.6 & 58.8 & 61.5 & 55.4 & 55.1 & 59.9 \\
\hline (7) & 40.1 & 307 & 41.1 & 38.2 & 63.0 & $40.1 * * *$ & 36.0 & 41.3 & 41.7 & 37.8 & 34.5 & 43.1 & 39.2 & 41.8 & 44.4 & 38.0 \\
\hline (8) & 39.5 & 306 & 38.7 & 42.6 & 69.6 & $39.5 * * *$ & 41.9 & 38.2 & 31.9 & $45.9 * *$ & 31.9 & $44.1 * *$ & 33.6 & $44.9 * *$ & 49.1 & $35.1 * *$ \\
\hline (9) & 26.5 & 306 & 25.5 & 27.9 & 69.6 & $26.5 * * *$ & 36.5 & $22.7 * *$ & 24.3 & 29.1 & 30.1 & 25.0 & 35.7 & $19.0 * * *$ & 32.4 & 23.6 \\
\hline
\end{tabular}


Table 5

Survey responses to the question: Do these statements describe why your company tries to avoid missing an earnings benchmark?

See Table 3 header for table and variable descriptions.

\section{Panel A: Unconditional averages}

\begin{tabular}{|c|c|c|c|c|c|}
\hline Question & & $\begin{array}{c}\% \text { agree or strongly } \\
\text { agree }\end{array}$ & $\begin{array}{c}\% \text { disagree or } \\
\text { strongly disagree }\end{array}$ & Average rating & $\begin{array}{c}\boldsymbol{H}_{0}: \text { Average } \\
\text { rating }=0\end{array}$ \\
\hline$(1)$ & it creates uncertainty about our future prospects & $80.7 \%$ & $7.5 \%$ & 0.97 & $* * *$ \\
\hline$(2)$ & outsiders might think there are previously unknown problems at our firm & $60.0 \%$ & $18.7 \%$ & 0.49 & $* * *$ \\
\hline (3) & we have to spend a lot of time explaining why we missed rather than focus on future & $58.2 \%$ & $18.6 \%$ & 0.48 & $* * *$ \\
\hline (4) & it leads to increased scrutiny of all aspects of our earnings releases & $37.6 \%$ & $28.4 \%$ & 0.07 & \\
\hline (5) & outsiders might think that our firm lacks the flexibility to meet the benchmark & $28.1 \%$ & $36.3 \%$ & -0.14 & $* *$ \\
\hline$(6)$ & it increases the possibility of lawsuits & $25.7 \%$ & $37.8 \%$ & -0.20 & $* * *$ \\
\hline
\end{tabular}

Panel B: Conditional averages

\begin{tabular}{|c|c|c|c|c|c|c|c|c|c|c|c|c|c|c|c|c|c|c|}
\hline \multirow[t]{2}{*}{ Question } & \multirow{2}{*}{$\begin{array}{c}\% \text { agree or } \\
\text { strongly } \\
\text { agree }\end{array}$} & \multirow[t]{2}{*}{ Obs. } & \multicolumn{2}{|c|}{ Size } & \multicolumn{2}{|c|}{$P / E$} & \multicolumn{2}{|c|}{ Sales growth } & \multicolumn{2}{|c|}{ Debt to assets } & \multicolumn{2}{|c|}{ Credit rating } & \multicolumn{2}{|c|}{ Tech industry } & \multicolumn{2}{|c|}{ Insider } & \multicolumn{2}{|c|}{ Exchange } \\
\hline & & & Small & Large & Low & High & Low & High & Low & High & Low & High & Other & Tech & Low & High & $\begin{array}{c}\text { NASDAQ/ } \\
\text { Amex }\end{array}$ & NYSE \\
\hline (1) & 80.7 & 306 & 78.4 & 82.8 & 73.4 & $85.6 * *$ & 76.7 & $84.9 *$ & 78.3 & 81.3 & 73.6 & $83.6 *$ & 79.3 & 87.8 & 76.3 & 83.5 & 77.2 & 83.2 \\
\hline$(2)$ & 60.0 & 305 & 58.5 & 62.3 & 55.5 & 53.6 & 56.8 & 61.1 & 56.2 & 59.4 & 58.7 & 59.4 & 58.2 & $72.5 *$ & 54.4 & $64.4 *$ & 56.8 & 62.2 \\
\hline (3) & 58.2 & 306 & 60.4 & 56.7 & 60.6 & 51.5 & 55.1 & 59.2 & 53.8 & 59.4 & 66.3 & $54.3 *$ & 56.6 & $70.7 *$ & 48.5 & $65.6 * * *$ & 59.8 & 57.0 \\
\hline (4) & 37.6 & 306 & 33.8 & 41.1 & 39.1 & 35.1 & 38.8 & 36.5 & 35.4 & 38.8 & 37.0 & 41.4 & 36.2 & 45.0 & 33.1 & 40.2 & 31.0 & $42.2 * *$ \\
\hline (5) & 28.1 & 306 & 22.3 & $32.5 * *$ & 29.1 & 32.0 & 22.4 & 34.9 ** & 27.7 & 28.1 & 21.7 & 33.6 ** & 26.8 & 35.0 & 22.1 & $32.9 * *$ & 23.8 & 31.1 \\
\hline (6) & 25.7 & 307 & 30.2 & $21.2 *$ & 20.9 & 27.8 & 21.8 & 30.2 & 28.5 & 23.7 & 32.6 & $17.2 * * *$ & 21.8 & $48.8 * * *$ & 22.1 & 28.0 & 32.3 & $21.1 * *$ \\
\hline
\end{tabular}

\begin{tabular}{|c|c|c|c|c|c|c|c|c|c|c|c|c|c|c|c|c|}
\hline \multirow[t]{2}{*}{ Question } & \multirow[t]{2}{*}{$\begin{array}{c}\% \text { agree or } \\
\text { strongly } \\
\text { agree }\end{array}$} & \multirow[t]{2}{*}{ Obs. } & \multicolumn{2}{|c|}{ CEO age } & \multicolumn{2}{|c|}{ Ownership } & \multicolumn{2}{|c|}{ Profitable } & \multicolumn{2}{|c|}{ Firm age } & \multicolumn{2}{|c|}{ Guidance } & \multicolumn{2}{|c|}{$\begin{array}{c}\text { Number of } \\
\text { analysts }\end{array}$} & \multicolumn{2}{|c|}{ CEO education } \\
\hline & & & Young 1 & ature & Private & Public & No & Yes & Young & Old & Little & Much & Few & Many & MBA & Other \\
\hline (1) & 80.7 & 306 & 80.4 & 83.8 & 58.7 & $80.7 * * *$ & 81.3 & 80.4 & 81.8 & 78.4 & 69.9 & $87.2 * * *$ & 76.9 & 84.1 & 78.7 & 81.7 \\
\hline (2) & 60.0 & 305 & 62.1 & 52.9 & 63.0 & 60.0 & 65.8 & 56.9 & 63.9 & $53.7 *$ & 52.7 & $64.9 * *$ & 55.6 & 63.9 & 66.7 & 55.0 ** \\
\hline (3) & 58.2 & 306 & 57.0 & 61.8 & 58.7 & 58.2 & 58.7 & 57.1 & 60.8 & 54.7 & 55.8 & 59.9 & 60.8 & 56.7 & 54.6 & 60.2 \\
\hline (4) & 37.6 & 306 & 36.2 & 42.6 & 37.0 & 37.6 & 39.2 & 36.4 & 35.4 & 39.2 & 29.2 & $42.6 * *$ & 33.6 & 41.8 & 31.5 & $41.4 *$ \\
\hline (5) & 28.1 & 306 & 26.8 & 32.4 & 34.8 & 28.1 & 20.3 & $30.7 *$ & 28.5 & 27.0 & 19.5 & $33.5 * * *$ & 23.8 & $32.3 *$ & 24.1 & 29.8 \\
\hline (6) & 25.7 & 307 & 25.4 & 26.5 & 4.3 & $25.7 * * *$ & 36.0 & $22.7 * *$ & 31.3 & $20.9 * *$ & 23.9 & 26.1 & 27.3 & 24.1 & 20.4 & 28.1 \\
\hline
\end{tabular}


Table 6

Survey responses to the question: Hypothetical scenario: Near the end of the quarter, it looks like your company might come in below the desired earnings target. Within what is permitted by GAAP, which of the following choices might your company make?

See Table 3 header for table and variable descriptions.

Panel A: Unconditional averages

\begin{tabular}{|c|c|c|c|c|c|}
\hline Question & & $\begin{array}{c}\text { \% agree or strongly } \\
\text { agree }\end{array}$ & $\begin{array}{c}\% \text { disagree or } \\
\text { strongly disagree }\end{array}$ & Average rating & $\begin{array}{c}\boldsymbol{H}_{0}: \text { Average } \\
\text { rating }=0\end{array}$ \\
\hline (1) & decrease discretionary spending (e.g. R\&D advertising maintenance etc.) & $79.9 \%$ & $11.2 \%$ & 1.00 & $* * *$ \\
\hline (2) & delay starting a new project even if this entails a small sacrifice in value & $55.3 \%$ & $23.5 \%$ & 0.33 & $* * *$ \\
\hline (3) & book revenues now rather than next quarter (if justified in either quarter) & $40.4 \%$ & $38.1 \%$ & -0.12 & \\
\hline (4) & provide incentives for customers to buy more product this quarter & $39.1 \%$ & $40.8 \%$ & -0.11 & \\
\hline (5) & draw down on reserves previously set aside & $27.9 \%$ & $50.5 \%$ & -0.45 & $* * *$ \\
\hline (6) & postpone taking an accounting charge & $21.3 \%$ & $62.7 \%$ & -0.72 & $* * *$ \\
\hline (7) & sell investments or assets to recognize gains this quarter & $20.2 \%$ & $61.3 \%$ & -0.77 & $* * *$ \\
\hline (9) & alter accounting assumptions (e.g. allowances pensions etc.) & $7.9 \%$ & $78.2 \%$ & -1.22 & $* * *$ \\
\hline
\end{tabular}

Panel B: Conditional averages

\begin{tabular}{|c|c|c|c|c|c|c|c|c|c|c|c|c|c|c|c|c|c|c|}
\hline \multirow[t]{2}{*}{ Question } & \multirow{2}{*}{$\begin{array}{c}\% \text { agree or } \\
\text { strongly } \\
\text { agree }\end{array}$} & \multirow[t]{2}{*}{ Obs. } & \multicolumn{2}{|r|}{ Size } & \multicolumn{2}{|c|}{$P / E$} & \multicolumn{2}{|c|}{ Sales growth } & \multicolumn{2}{|c|}{ Debt to assets } & \multicolumn{2}{|c|}{ Credit rating } & \multicolumn{2}{|c|}{ Tech industry } & \multicolumn{2}{|c|}{ Insider } & \multicolumn{2}{|c|}{ Exchange } \\
\hline & & & Small & Large & Low & High & Low & High & Low & High & Low & High & Other & Tech & Low & High & $\begin{array}{c}\text { NASDAQ/ } \\
\text { Amex }\end{array}$ & NYSE \\
\hline (1) & 79.9 & 304 & 80.4 & 80.5 & 75.0 & 80.2 & 82.3 & 77.2 & 82.3 & 75.0 & 73.6 & 78.3 & 78.8 & $90.0 * *$ & 78.5 & 80.2 & 81.1 & 79.1 \\
\hline (2) & 55.3 & 302 & 54.8 & 57.0 & 44.6 & $57.3 *$ & 57.8 & 54.0 & 55.4 & 54.0 & 65.9 & $44.5 * * *$ & 52.8 & $71.8 * *$ & 51.5 & 58.0 & 54.0 & 56.3 \\
\hline (3) & 40.4 & 302 & 43.5 & 37.8 & 34.8 & 34.7 & 43.2 & 36.2 & 37.2 & 41.4 & 37.4 & 39.1 & 39.0 & $53.8 *$ & 37.3 & 41.4 & 39.7 & 40.9 \\
\hline (4) & 39.1 & 304 & 44.6 & $33.6 * *$ & 27.7 & $38.5 *$ & 38.1 & 41.7 & 40.0 & 40.0 & 38.5 & 30.2 & 36.1 & $62.5 * * *$ & 32.6 & $43.2 *$ & 45.7 & $34.5 * *$ \\
\hline (5) & 27.9 & 301 & 28.6 & 27.9 & 27.3 & 25.0 & 25.5 & 29.1 & 25.4 & 29.7 & 26.7 & 27.3 & 28.9 & 28.2 & 24.1 & 30.2 & 24.6 & 30.3 \\
\hline (6) & 21.3 & 300 & 21.1 & 21.9 & 23.4 & 16.0 & 21.4 & 20.6 & 15.5 & $23.9 *$ & 25.6 & 19.7 & 22.6 & 17.9 & 21.1 & 20.5 & 19.8 & 22.4 \\
\hline (7) & 20.2 & 302 & 20.4 & 20.3 & 16.2 & 22.9 & 19.7 & 20.6 & 19.2 & 20.1 & 13.2 & $23.4 * *$ & 19.7 & 28.2 & 20.9 & 18.5 & 18.3 & 21.6 \\
\hline (8) & 12.4 & 298 & 11.6 & 13.8 & 16.2 & 12.0 & 9.6 & $17.9 * *$ & 15.9 & 9.4 & 11.0 & 12.9 & 13.5 & 7.7 & 7.6 & $16.1 * *$ & 12.0 & 12.7 \\
\hline (9) & 7.9 & 303 & 8.8 & 7.4 & 10.7 & $4.2 *$ & 9.5 & 6.3 & 6.2 & 10.0 & 11.0 & 7.0 & 7.5 & 12.8 & 5.9 & 8.6 & 9.5 & 6.8 \\
\hline
\end{tabular}

\begin{tabular}{|c|c|c|c|c|c|c|c|c|c|c|c|c|c|c|c|c|}
\hline \multirow[t]{2}{*}{ Question } & \multirow[t]{2}{*}{$\begin{array}{c}\% \text { agree or } \\
\text { strongly } \\
\text { agree }\end{array}$} & \multirow[t]{2}{*}{ Obs. } & \multicolumn{2}{|c|}{ CEO age } & \multicolumn{2}{|c|}{ Ownership } & \multicolumn{2}{|c|}{ Profitable } & \multicolumn{2}{|c|}{ Firm age } & \multicolumn{2}{|c|}{ Guidance } & \multicolumn{2}{|c|}{$\begin{array}{c}\text { Number of } \\
\text { analysts }\end{array}$} & \multicolumn{2}{|c|}{ CEO education } \\
\hline & & & Young & ature & Private & Public & No & Yes & Young & Old & Little & Much & Few & Many & MBA & Other \\
\hline (1) & 79.9 & 304 & 81.8 & 74.3 & 86.4 & 79.9 & 82.9 & 78.8 & 79.9 & 78.7 & 75.9 & 82.8 & 77.5 & 82.1 & 82.9 & 77.9 \\
\hline (2) & 55.3 & 302 & 58.5 & $45.7 *$ & 59.1 & 55.3 & 70.7 & $50.7 * * *$ & 56.9 & 55.0 & 50.0 & 58.9 & 55.3 & 55.8 & 56.2 & 55.9 \\
\hline (3) & 40.4 & 302 & 42.4 & 34.3 & 36.4 & 40.4 & 49.3 & $37.8 *$ & 40.6 & 39.3 & 35.7 & 43.2 & 45.1 & $35.5 *$ & 39.4 & 41.3 \\
\hline (4) & 39.1 & 304 & 40.7 & 32.9 & 43.2 & 39.1 & 56.6 & $33.2 * * *$ & 45.8 & $31.3 * * *$ & 34.8 & 41.9 & 40.8 & 37.2 & 36.2 & 40.0 \\
\hline (5) & 27.9 & 301 & 27.6 & 28.6 & 52.3 & $27.9 * * *$ & 32.0 & 26.8 & 27.8 & 27.7 & 26.8 & 28.3 & 28.2 & 27.3 & 23.8 & 29.9 \\
\hline (7) & 20.2 & 302 & 18.8 & 25.7 & 22.7 & 20.2 & 21.3 & 20.0 & 20.3 & 19.3 & 17.9 & 21.6 & 14.8 & $25.2 * *$ & 24.0 & 18.0 \\
\hline (8) & 12.4 & 298 & 13.2 & 10.4 & 4.7 & $12.4 * *$ & 6.7 & $14.5 * *$ & 14.0 & 11.0 & 10.0 & 14.2 & 9.9 & 14.5 & 12.5 & 12.4 \\
\hline (9) & 7.9 & 303 & 7.4 & 10.0 & 13.6 & 7.9 & 13.3 & $6.2 *$ & 6.3 & 9.3 & 6.3 & 9.1 & 9.9 & 5.8 & 4.8 & 9.5 \\
\hline
\end{tabular}


Table 7

Survey responses to the question: Hypothetical scenario: Your company's cost of capital is $12 \%$. Near the end of the quarter, a new opportunity arises that offers a $16 \%$ internal rate of return and the same risk as the firm. The analyst consensus EPS estimate is $\$ \mathbf{1 . 9 0}$. What is the probability that your company will pursue this project in each of the following scenarios?

See Table 3 header for table and variable descriptions.

Panel A: Unconditional averages

\begin{tabular}{|c|c|c|c|c|c|c|c|c|}
\hline & \multirow{3}{*}{$\begin{array}{c}\text { Average } \\
\text { probability of } \\
\text { pursuing } \\
\end{array}$} \\
\hline $\begin{array}{l}\text { EPS if you } \\
\text { do not } \\
\text { pursue }\end{array}$ & $\begin{array}{c}\text { EPS if you } \\
\text { pursue }\end{array}$ & \multicolumn{6}{|c|}{$\begin{array}{l}\text { Probability that the project will be } \\
\text { pursued: (Percent of respondents } \\
\text { indicating) }\end{array}$} & \\
\hline & & 0\% & $20 \%$ & $40 \%$ & $60 \%$ & $80 \%$ & $100 \%$ & \\
\hline$\$ 2.00$ & $\$ 1.90$ & $4 \%$ & $4 \%$ & $5 \%$ & $10 \%$ & $32 \%$ & $45 \%$ & $80 \%$ \\
\hline$\$ 1.90$ & $\$ 1.80$ & $10 \%$ & $14 \%$ & $10 \%$ & $20 \%$ & $28 \%$ & $18 \%$ & $59 \%$ \\
\hline$\$ 1.80$ & $\$ 1.70$ & $14 \%$ & $12 \%$ & $13 \%$ & $21 \%$ & $22 \%$ & $17 \%$ & $55 \%$ \\
\hline$\$ 1.40$ & $\$ 1.30$ & $20 \%$ & $13 \%$ & $12 \%$ & $15 \%$ & $20 \%$ & $19 \%$ & $52 \%$ \\
\hline
\end{tabular}

Panel B: Conditional averages

\begin{tabular}{|c|c|c|c|c|c|c|c|c|c|c|c|c|c|c|c|c|c|c|c|}
\hline \multirow[t]{2}{*}{$\begin{array}{c}\text { EPS if you } \\
\text { do not } \\
\text { pursue }\end{array}$} & \multirow[t]{2}{*}{$\begin{array}{c}\text { EPS if you } \\
\text { pursue }\end{array}$} & \multirow[t]{2}{*}{ Avg prob. } & \multirow[t]{2}{*}{ Obs. } & \multicolumn{2}{|c|}{ Size } & \multicolumn{2}{|c|}{$P / E$} & \multicolumn{2}{|c|}{ Sales growth } & \multicolumn{2}{|c|}{ Debt to assets } & \multicolumn{2}{|c|}{ Credit rating } & \multicolumn{2}{|c|}{ Tech industry } & \multicolumn{2}{|c|}{ Insider } & \multicolumn{2}{|c|}{ Exchange } \\
\hline & & & & Small & Large & Low & High & Low & High & Low & High & Low & High & Other & Tech & Low & High & $\begin{array}{c}\text { NASDAQ/ } \\
\text { Amex }\end{array}$ & NYSE \\
\hline$\$ 2.00$ & $\$ 1.90$ & $80 \%$ & 284 & 78.4 & 81.8 & 79.5 & 79.1 & 80.0 & 78.2 & 78.4 & 81.0 & 81.4 & 78.0 & 80.8 & 74.2 & 80.4 & 79.0 & 77.5 & 80.9 \\
\hline$\$ 1.90$ & $\$ 1.80$ & $59 \%$ & 284 & 59.2 & 60.1 & 63.1 & 55.9 & 60.6 & 56.4 & 57.4 & 61.4 & 58.1 & 61.3 & 61.2 & $50.6 *$ & 61.6 & 57.8 & 55.7 & 61.5 \\
\hline$\$ 1.80$ & $\$ 1.70$ & $55 \%$ & 284 & 55.1 & 56.2 & 56.7 & 52.8 & 55.6 & 53.4 & 54.0 & 57.5 & 58.1 & 56.1 & 57.9 & $45.0 * *$ & 58.0 & 53.6 & 52.9 & 56.9 \\
\hline$\$ 1.40$ & $\$ 1.30$ & $52 \%$ & 284 & 50.4 & 53.7 & 51.8 & 50.2 & 52.1 & 50.7 & 52.5 & 51.7 & 56.9 & 51.3 & 53.8 & 45.6 & 54.2 & 50.4 & 51.7 & 51.8 \\
\hline
\end{tabular}

\begin{tabular}{|c|c|c|c|c|c|c|c|c|c|c|c|c|c|c|c|c|c|}
\hline \multirow[t]{2}{*}{$\begin{array}{c}\text { EPS if you } \\
\text { do not } \\
\text { pursue }\end{array}$} & \multirow[t]{2}{*}{$\begin{array}{c}\text { EPS if you } \\
\text { pursue }\end{array}$} & \multirow[t]{2}{*}{ Avg prob. } & \multirow[t]{2}{*}{ Obs. } & \multicolumn{2}{|c|}{ CEO age } & \multicolumn{2}{|c|}{ Ownership } & \multicolumn{2}{|c|}{ Profitable } & \multicolumn{2}{|c|}{ Firm age } & \multicolumn{2}{|c|}{ Guidance } & \multicolumn{2}{|c|}{$\begin{array}{c}\text { Number of } \\
\text { analysts }\end{array}$} & \multicolumn{2}{|c|}{ CEO education } \\
\hline & & & & Young & Mature & Private & Public & No & Yes & Young & Old & Little & Much & Few & Many & MBA & Other \\
\hline$\$ 2.00$ & $\$ 1.90$ & $80 \%$ & 284 & 79.5 & 79.5 & 79.1 & 79.6 & 79.0 & 79.7 & 79.3 & 79.4 & 81.1 & 78.7 & 80.1 & 78.9 & 78.9 & 79.8 \\
\hline$\$ 1.90$ & $\$ 1.80$ & $59 \%$ & 284 & 58.4 & 61.3 & 62.8 & 59.2 & 56.9 & 59.8 & 57.7 & 60.0 & 64.3 & $56.0 * *$ & 60.2 & 58.3 & 58.5 & 59.0 \\
\hline$\$ 1.80$ & $\$ 1.70$ & $55 \%$ & 284 & 54.3 & 57.8 & 52.6 & 55.3 & 56.0 & 54.9 & 53.1 & 56.6 & 60.9 & $52.0 * *$ & 56.4 & 54.4 & 52.9 & 55.8 \\
\hline$\$ 1.40$ & $\$ 1.30$ & $52 \%$ & 284 & 51.0 & 52.7 & 46.0 & 51.7 & 53.7 & 50.8 & 50.4 & 52.9 & 54.5 & 50.5 & 52.8 & 51.1 & 47.9 & 52.9 \\
\hline
\end{tabular}


Table 8

Survey responses to the question: Do the following factors contribute to your company preferring a smooth earnings path?

See Table 3 header for table and variable descriptions.

\begin{tabular}{|c|c|c|c|c|c|}
\hline Question & A smooth earnings path is preferred because it... & $\begin{array}{c}\text { \% agree or strongly } \\
\text { agree }\end{array}$ & $\begin{array}{c}\text { \% disagree or } \\
\text { strongly disagree }\end{array}$ & Average rating & $\begin{array}{c}\boldsymbol{H}_{0}: \text { Average } \\
\text { rating }=0\end{array}$ \\
\hline$(1)$ & is perceived as less risky by investors & $88.7 \%$ & $2.3 \%$ & 1.18 & $* * *$ \\
\hline (2) & makes it easier for analysts/investors to predict future earnings & $79.7 \%$ & $2.7 \%$ & 0.99 & $* * *$ \\
\hline (3) & assures customers/suppliers that business is stable & $66.2 \%$ & $13.2 \%$ & 0.61 & $* * *$ \\
\hline (4) & reduces the return that investors demand (i.e. smaller risk premium) & $57.1 \%$ & $11.3 \%$ & 0.55 & $* * *$ \\
\hline (5) & promotes a reputation for transparent and accurate reporting & $46.5 \%$ & $18.6 \%$ & 0.32 & $* * *$ \\
\hline (6) & conveys higher future growth prospects & $46.3 \%$ & $12.4 \%$ & 0.42 & $* * *$ \\
\hline (7) & achieves or preserves a desired credit rating & $42.2 \%$ & $18.9 \%$ & 0.21 & $* * *$ \\
\hline (8) & clarifies true economic performance & $24.3 \%$ & $26.0 \%$ & -0.05 & \\
\hline (9) & increases bonus payments & $15.6 \%$ & $42.5 \%$ & -0.43 & $* * *$ \\
\hline
\end{tabular}

Panel B: Conditional averages

\begin{tabular}{|c|c|c|c|c|c|c|c|c|c|c|c|c|c|c|c|c|c|c|}
\hline \multirow[t]{2}{*}{ Question } & \multirow{2}{*}{$\begin{array}{c}\% \text { agree or } \\
\text { strongly } \\
\text { agree }\end{array}$} & \multirow[t]{2}{*}{ Obs. } & \multicolumn{2}{|c|}{ Size } & \multicolumn{2}{|c|}{$P / E$} & \multicolumn{2}{|c|}{ Sales growth } & \multicolumn{2}{|c|}{ Debt to assets } & \multicolumn{2}{|c|}{ Credit rating } & \multicolumn{2}{|c|}{ Tech industry } & \multicolumn{2}{|c|}{ Insider } & \multicolumn{2}{|c|}{ Exchange } \\
\hline & & & Small & Large & Low & High & Low & High & Low & High & Low & High & Other & Tech & Low & High & $\begin{array}{c}\text { NASDAQ/ } \\
\text { Amex }\end{array}$ & NYSE \\
\hline$(1)$ & 88.7 & 302 & 85.6 & $91.9 *$ & 92.9 & $81.1 * *$ & 88.1 & 87.1 & 84.4 & $91.1 *$ & 91.2 & 88.1 & 87.7 & $95.1 *$ & 87.1 & 89.6 & 85.5 & 91.0 \\
\hline (2) & 79.7 & 301 & 76.6 & 81.9 & 76.8 & 82.1 & 81.1 & 78.2 & 76.6 & 83.0 & 80.2 & 80.2 & 79.8 & 80.0 & 81.8 & 78.0 & 76.4 & 82.0 \\
\hline (3) & 66.2 & 302 & 73.3 & $59.1 * * *$ & 62.5 & 64.2 & 67.8 & 65.3 & 64.8 & 65.9 & 62.6 & 62.7 & 63.9 & $82.9 * * *$ & 60.6 & $71.3 *$ & 70.2 & 63.5 \\
\hline (4) & 57.1 & 301 & 53.1 & 61.1 & 60.7 & $48.4 *$ & 58.7 & 54.8 & 53.1 & 60.0 & 57.1 & 56.3 & 56.0 & $70.0 *$ & 59.1 & 56.1 & 56.1 & 57.9 \\
\hline (5) & 46.5 & 301 & 44.8 & 48.3 & 43.8 & 45.3 & 43.4 & 45.2 & 47.7 & 41.5 & 41.8 & 47.6 & 45.2 & 47.5 & 43.2 & 48.2 & 48.0 & 45.5 \\
\hline (6) & 46.3 & 298 & 45.1 & 46.9 & 45.0 & 43.6 & 42.6 & 48.0 & 44.1 & 44.4 & 36.3 & 45.2 & 46.6 & 42.5 & 39.2 & $52.1 * *$ & 51.6 & 42.6 \\
\hline (7) & 42.2 & 301 & 35.2 & $49.0 * *$ & 42.3 & 40.0 & 42.7 & 40.7 & 35.2 & $45.5 *$ & 40.0 & 50.0 & 44.2 & $29.3 *$ & 40.9 & 42.9 & 31.5 & $49.7 * * *$ \\
\hline (8) & 24.3 & 300 & 23.6 & 24.8 & 20.7 & 25.3 & 19.6 & 24.4 & 19.5 & 26.1 & 17.8 & 27.0 & 25.1 & 22.5 & 25.0 & 23.3 & 21.1 & 26.6 \\
\hline (9) & 15.6 & 301 & 19.3 & $12.1 *$ & 14.4 & 12.6 & 14.0 & 13.8 & 18.0 & 11.2 & 5.6 & $18.3 * * *$ & 15.5 & 17.1 & 11.4 & 17.8 & 21.8 & $11.3 * *$ \\
\hline
\end{tabular}

\begin{tabular}{|c|c|c|c|c|c|c|c|c|c|c|c|c|c|c|c|c|}
\hline \multirow[t]{2}{*}{ Question } & \multirow[t]{2}{*}{$\begin{array}{c}\text { \% agree or } \\
\text { strongly } \\
\text { agree }\end{array}$} & \multirow[t]{2}{*}{ Obs. } & \multicolumn{2}{|c|}{ CEO age } & \multicolumn{2}{|c|}{ Ownership } & \multicolumn{2}{|c|}{ Profitable } & \multicolumn{2}{|c|}{ Firm age } & \multicolumn{2}{|c|}{ Guidance } & \multicolumn{2}{|c|}{$\begin{array}{c}\text { Number of } \\
\text { analysts }\end{array}$} & \multicolumn{2}{|c|}{ CEO education } \\
\hline & & & Young & Mature & Private & Public & No & Yes & Young & Old & Little & Much & Few & Many & MBA & Other \\
\hline (1) & 88.7 & 302 & 89.6 & 85.3 & 79.1 & 88.7 & 87.1 & 88.9 & 87.2 & 89.0 & 87.2 & 90.4 & 90.0 & 87.8 & 92.4 & 86.8 \\
\hline (2) & 79.7 & 301 & 80.9 & 75.0 & 62.8 & $79.7 * *$ & 78.3 & 80.0 & 78.0 & 80.8 & 75.2 & $83.4 *$ & 75.0 & $85.3 * *$ & 80.0 & 80.3 \\
\hline (3) & 66.2 & 302 & 64.9 & 70.6 & 83.7 & $66.2 * * *$ & 74.3 & $63.1 *$ & 70.2 & 63.7 & 68.8 & 64.7 & 73.6 & $60.9 * *$ & 62.9 & 68.8 \\
\hline (4) & 57.1 & 301 & 56.1 & 60.3 & 48.8 & 57.1 & 59.4 & 56.0 & 56.0 & 56.8 & 50.5 & $61.0 *$ & 57.1 & 57.7 & 55.2 & 59.0 \\
\hline (5) & 46.5 & 301 & 44.3 & 52.9 & 41.9 & 46.5 & 43.5 & 45.8 & 48.9 & 40.4 & 35.8 & $51.9 * * *$ & 43.6 & 48.1 & 46.7 & 46.3 \\
\hline (6) & 46.3 & 298 & 46.9 & 42.6 & 53.5 & 46.3 & 42.6 & 47.1 & 46.4 & 44.4 & 40.7 & 49.7 & 44.6 & 48.7 & 43.8 & 47.3 \\
\hline (7) & 42.2 & 301 & 40.9 & 47.1 & 74.4 & $42.2 * * *$ & 44.3 & 40.2 & 35.0 & $48.6 * *$ & 38.0 & 44.4 & 39.6 & 44.2 & 41.0 & 44.1 \\
\hline (8) & 24.3 & 300 & 25.3 & 20.6 & 27.9 & 24.3 & 17.4 & 25.4 & 25.7 & 19.9 & 17.6 & $28.3 * *$ & 18.7 & $28.2 *$ & 21.0 & 26.2 \\
\hline (9) & 15.6 & 301 & 16.1 & 14.7 & 20.9 & 15.6 & 15.7 & 14.7 & 16.4 & 11.6 & 14.8 & 15.0 & 15.8 & 14.7 & 12.4 & 17.6 \\
\hline
\end{tabular}


Table 9

Survey responses to the question: How large a sacrifice in value would your firm make to avoid a bumpy earnings path?

Panel A presents the percent of all respondents from public firms indicating each choice. See Table 3 header for table and variable descriptions for Panel B.

\section{Panel A: Unconditional averages}

$\%$ of

respondents

none $\quad 22.0 \%$

small sacrifice $\quad 52.0 \%$

moderate sacrifice $\quad 24.0 \%$

large sacrifice $\quad 2.0 \%$

Panel B: Conditional averages

\begin{tabular}{|c|c|c|c|c|c|c|c|c|c|c|c|c|c|c|c|c|c|c|}
\hline \multirow[t]{2}{*}{ Response } & \multirow[t]{2}{*}{$\begin{array}{c}\% \text { of } \\
\text { respondents }\end{array}$} & \multirow[t]{2}{*}{ Obs. } & \multicolumn{2}{|c|}{ Size } & \multicolumn{2}{|c|}{$P / E$} & \multicolumn{2}{|c|}{ Sales growth } & \multicolumn{2}{|c|}{ Debt to assets } & \multicolumn{2}{|c|}{ Credit rating } & \multicolumn{2}{|c|}{ Tech industry } & \multicolumn{2}{|c|}{ Insider } & \multicolumn{2}{|c|}{ Exchange } \\
\hline & & & Small & Large & Low & High & Low & High & Low & High & Low & High & Other & Tech & Low & High & $\begin{array}{c}\text { NASDAQ/ } \\
\text { Amex }\end{array}$ & NYSE \\
\hline none & $22.0 \%$ & 302 & 23.3 & 21.8 & 28.6 & 20.2 & 20.6 & 23.0 & 23.4 & 21.5 & 26.4 & 21.8 & 23.8 & $7.7 * * *$ & 22.7 & 22.0 & 18.9 & 24.2 \\
\hline small sacrifice & $52.0 \%$ & 302 & 51.4 & 51.7 & 51.8 & 52.1 & 57.4 & 49.2 & 53.9 & 52.6 & 49.5 & 51.6 & 49.2 & $71.8 * * *$ & 56.1 & 49.4 & 58.2 & $47.8 *$ \\
\hline moderate sacrifice & $24.0 \%$ & 302 & 24.0 & 23.8 & 18.8 & 23.4 & 20.6 & 24.6 & 20.3 & 23.7 & 24.2 & 25.0 & 24.6 & 20.5 & 18.2 & $27.4 *$ & 22.1 & 25.3 \\
\hline large sacrifice & $2.0 \%$ & 302 & 1.4 & 2.7 & 0.9 & 4.3 & 1.4 & 3.2 & 2.3 & 2.2 & & 1.6 & 2.4 & & 3.0 & 1.2 & 0.8 & 2.8 \\
\hline
\end{tabular}

\begin{tabular}{|c|c|c|c|c|c|c|c|c|c|c|c|c|c|c|c|c|}
\hline \multirow[t]{2}{*}{ Response } & \multirow[t]{2}{*}{$\begin{array}{c}\% \text { of } \\
\text { respondents }\end{array}$} & \multirow[t]{2}{*}{ Obs. } & \multicolumn{2}{|c|}{ CEO age } & \multicolumn{2}{|c|}{ Ownership } & \multicolumn{2}{|c|}{ Profitable } & \multicolumn{2}{|c|}{ Firm age } & \multicolumn{2}{|c|}{ Guidance } & \multicolumn{2}{|c|}{$\begin{array}{c}\text { Number of } \\
\text { analysts }\end{array}$} & \multicolumn{2}{|c|}{ CEO education } \\
\hline & & & Young & ature & Private & Public & No & Yes & Young & Old & Little & Much & Few & Many & MBA & Other \\
\hline none & $22.0 \%$ & 302 & 21.7 & 20.9 & 14.3 & 22.0 & 18.6 & 23.3 & 23.2 & 20.7 & 28.4 & $18.3 * *$ & 24.1 & 19.4 & 21.7 & 21.4 \\
\hline small sacrifice & $52.0 \%$ & 302 & 51.7 & 53.7 & 57.1 & 52.0 & 57.1 & 50.7 & 54.2 & 50.3 & 48.6 & 53.2 & 50.4 & 54.2 & 50.9 & 52.4 \\
\hline moderate sacrifice & $24.0 \%$ & 302 & 24.8 & 22.4 & 23.8 & 24.0 & 21.4 & 24.2 & 21.1 & 26.2 & 21.1 & 26.3 & 23.4 & 24.5 & 24.5 & 24.6 \\
\hline large sacrifice & $2.0 \%$ & 302 & 1.7 & 3.0 & 4.8 & 2.0 & 2.9 & 1.8 & 1.4 & 2.8 & 1.8 & 2.2 & 2.1 & 1.9 & 2.8 & 1.6 \\
\hline
\end{tabular}




\section{Table 10}

Survey responses to the question: Rank the two most important groups in terms of setting the stock price for your company.

Points are assigned as follow: 2 points for a \#1 ranking; 1 point for a \#2 ranking. See Table 3 header for additional table and variable descriptions

Panel A: Unconditional averages

\begin{tabular}{lcccc}
\multicolumn{1}{c}{ Group } & \#1 Rankings & $\begin{array}{c}\text { Ranki } \\
\text { ngs }\end{array}$ & Total points & $\begin{array}{c}\text { Average } \\
\text { points }\end{array}$ \\
\hline institutional investors & 163 & 103 & 429 & 1.4 \\
analysts & 108 & 111 & 327 & 1.0 \\
individual investors & 20 & 39 & 79 & 0.3 \\
rating agencies & 5 & 21 & 31 & 0.1 \\
hedge funds & 5 & 16 & 26 & 0.1 \\
\hline
\end{tabular}

Panel B: Conditional averages

\begin{tabular}{|c|c|c|c|c|c|c|c|c|c|c|c|c|c|c|c|c|}
\hline \multirow[t]{2}{*}{ Group } & \multirow[t]{2}{*}{$\begin{array}{c}\text { Average } \\
\text { points }\end{array}$} & \multirow[t]{2}{*}{ Obs. } & \multicolumn{2}{|c|}{ Size } & \multicolumn{2}{|c|}{$P / E$} & \multicolumn{2}{|c|}{ Sales Growth } & \multicolumn{2}{|c|}{$D / A$} & \multicolumn{2}{|c|}{ Credit Rating } & \multicolumn{2}{|c|}{ Tech Industry } & \multicolumn{2}{|c|}{ Insider } \\
\hline & & & Small & Large & Low & High & Low & High & Low & High & Low & High & Other & Tech & Low & High \\
\hline institutional investors & 1.4 & 312 & 1.41 & 1.33 & 1.36 & $1.56 * *$ & 1.38 & 1.41 & 1.51 & $1.32 * *$ & 1.42 & 1.49 & 1.37 & 1.45 & 1.46 & 1.34 \\
\hline analysts & 1.0 & 312 & 0.87 & $1.21 * * *$ & 1.05 & 1.03 & 1.06 & 1.09 & 1.02 & 1.08 & 1.02 & 1.16 & 1.04 & 1.07 & 1.08 & 0.99 \\
\hline individual investors & 0.3 & 312 & 0.39 & $0.12 * * *$ & 0.34 & 0.22 & 0.32 & 0.22 & 0.34 & $0.21 *$ & 0.31 & $0.16 * *$ & 0.26 & 0.21 & 0.21 & 0.29 \\
\hline rating agencies & 0.1 & 312 & 0.05 & $0.15 * *$ & 0.07 & 0.08 & 0.10 & 0.11 & 0.05 & $0.16 * * *$ & 0.14 & 0.09 & 0.12 & $0.00 * *$ & 0.09 & 0.09 \\
\hline hedge funds & 0.1 & 312 & 0.09 & 0.07 & 0.09 & 0.07 & 0.09 & 0.09 & 0.09 & 0.09 & 0.09 & 0.09 & 0.08 & 0.14 & 0.09 & 0.08 \\
\hline
\end{tabular}

\begin{tabular}{|c|c|c|c|c|c|c|c|c|c|c|c|c|c|c|c|c|}
\hline \multirow[t]{2}{*}{ Group } & \multirow[t]{2}{*}{$\begin{array}{c}\text { Average } \\
\text { points }\end{array}$} & \multirow[t]{2}{*}{ Obs. } & \multicolumn{2}{|c|}{ CEO age } & \multicolumn{2}{|c|}{ Ownership } & \multicolumn{2}{|c|}{ Profitable } & \multicolumn{2}{|c|}{ Firm age } & \multicolumn{2}{|c|}{ Guidance } & \multicolumn{2}{|c|}{$\begin{array}{c}\text { Number of } \\
\text { analysts }\end{array}$} & \multicolumn{2}{|c|}{ CEO education } \\
\hline & & & $\begin{array}{c}\text { NASDAQ/ } \\
\text { Amex }\end{array}$ & NYSE & Young & Mature & No & Yes & Young & Old & Little & Much & Few & Many & $M B A$ & Other \\
\hline institutional investors & 1.38 & 312 & 1.39 & 1.37 & 1.34 & 1.50 & 1.39 & 1.41 & 1.40 & 1.40 & 1.39 & 1.36 & 1.34 & 1.41 & 1.37 & 1.40 \\
\hline analysts & 1.05 & 312 & 0.96 & 1.11 & 1.06 & 1.03 & 1.00 & 1.09 & 1.05 & 1.08 & 0.82 & $1.18 * * *$ & 0.87 & $1.21 * * *$ & 1.02 & 1.08 \\
\hline individual investors & 0.25 & 312 & 0.35 & $0.19 * *$ & 0.25 & 0.29 & 0.21 & 0.28 & 0.25 & 0.29 & 0.49 & $0.11 * * *$ & 0.40 & $0.12 * * *$ & 0.33 & $0.22 *$ \\
\hline rating agencies & 0.10 & 312 & 0.05 & $0.14 * *$ & 0.11 & 0.06 & 0.17 & $0.08 * *$ & 0.09 & 0.12 & 0.05 & $0.13 *$ & 0.12 & 0.08 & 0.13 & 0.09 \\
\hline hedge funds & 0.08 & 312 & 0.09 & 0.08 & 0.08 & 0.07 & 0.11 & 0.08 & 0.12 & 0.05 & 0.14 & $0.05 * *$ & 0.09 & 0.08 & 0.04 & $0.10 *$ \\
\hline
\end{tabular}


Table 11

Survey responses to the question: Do these statements describe your company's motives for voluntarily communicating financial information?

See Table 3 header for table and variable descriptions.

\section{Panel A: Unconditional averages}

\begin{tabular}{|c|c|c|c|c|c|}
\hline Question & Voluntarily communicating information... & $\begin{array}{c}\text { \% agree or strongly } \\
\text { agree }\end{array}$ & $\begin{array}{c}\text { \% disagree or } \\
\text { strongly disagree }\end{array}$ & Average rating & $\begin{array}{c}\boldsymbol{H}_{0}: \text { Average } \\
\text { rating }=0\end{array}$ \\
\hline (1) & promotes a reputation for transparent/accurate reporting & $92.1 \%$ & $2.0 \%$ & 1.39 & $* * *$ \\
\hline (2) & reduces the "information risk" that investors assign to our stock & $81.9 \%$ & $4.3 \%$ & 1.03 & $* * *$ \\
\hline (3) & provides important information to investors that is not included in mandatory financial disclosures & $72.1 \%$ & $8.9 \%$ & 0.86 & $* * *$ \\
\hline (4) & increases the predictability of our company’s future prospects & $56.2 \%$ & $14.4 \%$ & 0.53 & $* * *$ \\
\hline (5) & attracts more financial analysts to follow our stock & $50.8 \%$ & $17.0 \%$ & 0.43 & $* * *$ \\
\hline (6) & corrects an under-valued stock price & $48.4 \%$ & $16.4 \%$ & 0.37 & $* * *$ \\
\hline (7) & increases the overall liquidity of our stock & $44.3 \%$ & $17.4 \%$ & 0.31 & $* * *$ \\
\hline (8) & increases our $\mathrm{P} / \mathrm{E}$ ratio & $42.0 \%$ & $18.0 \%$ & 0.27 & $* * *$ \\
\hline (9) & reveals to outsiders the skill level of our managers & $41.3 \%$ & $26.2 \%$ & 0.16 & ** \\
\hline (10) & reduces our cost of capital & $39.3 \%$ & $22.0 \%$ & 0.17 & *** \\
\hline (11) & reduces the risk premium employees demand for holding stock granted as compensation & $9.2 \%$ & $49.2 \%$ & -0.57 & *** \\
\hline
\end{tabular}

Panel B: Conditional averages

\begin{tabular}{|c|c|c|c|c|c|c|c|c|c|c|c|c|c|c|c|c|c|c|}
\hline \multirow[t]{2}{*}{ Question } & \multirow{2}{*}{$\begin{array}{c}\% \text { agree or } \\
\text { strongly } \\
\text { agree }\end{array}$} & \multirow[t]{2}{*}{ Obs. } & \multicolumn{2}{|c|}{ Size } & \multicolumn{2}{|c|}{$P / E$} & \multicolumn{2}{|c|}{ Sales growth } & \multicolumn{2}{|c|}{ Debt to assets } & \multicolumn{2}{|c|}{ Credit rating } & \multicolumn{2}{|c|}{ Tech industry } & \multicolumn{2}{|c|}{ Insider } & \multicolumn{2}{|c|}{ Exchange } \\
\hline & & & Small & Large & Low & High & Low & High & Low & High & Low & High & Other & Tech & Low & High & $\begin{array}{c}\text { NASDAQ/ } \\
\text { Amex }\end{array}$ & NYSE \\
\hline (1) & 92.1 & 305 & 90.6 & 94.0 & 92.9 & 90.7 & 89.1 & 93.8 & 88.5 & 93.6 & 91.3 & 94.6 & 91.4 & $97.6 * *$ & 91.2 & 92.6 & 91.3 & 92.7 \\
\hline (2) & 81.9 & 304 & 78.2 & 85.3 & 78.8 & 85.6 & 77.0 & 84.4 & 77.9 & 81.6 & 79.6 & 83.7 & 81.2 & 85.0 & 80.9 & 82.7 & 73.6 & $87.7 * * *$ \\
\hline (3) & 72.1 & 305 & 66.9 & $77.3 * *$ & 73.5 & 68.0 & 66.2 & $76.6 *$ & 66.4 & $75.9 *$ & 71.0 & 72.1 & 73.4 & 70.0 & 72.8 & 71.2 & 67.5 & 75.4 \\
\hline (4) & 56.2 & 306 & 47.7 & $64.7 * * *$ & 56.6 & 58.8 & 49.3 & $60.9 *$ & 49.6 & $61.7 * *$ & 51.6 & 62.0 & 57.0 & 53.7 & 54.4 & 56.4 & 49.6 & $60.9 * *$ \\
\hline (5) & 50.8 & 305 & 57.0 & $45.6 * *$ & 53.1 & 44.8 & 49.0 & 52.3 & 52.7 & 50.7 & 54.8 & 46.1 & 49.8 & 58.5 & 44.4 & $55.2 *$ & 56.7 & $46.6 *$ \\
\hline (6) & 48.4 & 304 & 51.0 & 46.7 & 48.7 & 48.5 & 46.3 & 50.8 & 46.9 & 51.1 & 55.4 & 45.7 & 46.7 & 60.0 & 46.7 & 49.7 & 50.0 & 47.2 \\
\hline (7) & 44.3 & 305 & 51.4 & $37.3 * *$ & 44.2 & 38.1 & 43.9 & 41.4 & 39.7 & $49.6 *$ & 45.2 & 37.2 & 43.8 & 47.5 & 46.3 & 42.9 & 50.8 & $39.7 *$ \\
\hline (8) & 42.0 & 305 & 43.2 & 41.3 & 43.4 & 50.5 & 33.8 & $50.8 * * *$ & 42.0 & 44.0 & 44.1 & 43.4 & 41.4 & 45.0 & 38.2 & 46.6 & 45.2 & 39.7 \\
\hline (9) & 41.3 & 305 & 45.9 & $36.0 *$ & 44.2 & 43.3 & 37.8 & $47.7 *$ & 38.2 & 44.0 & 40.9 & 41.1 & 40.6 & 47.5 & 42.6 & 41.1 & 43.7 & 39.7 \\
\hline (10) & 39.3 & 305 & 32.4 & $45.3 * *$ & 46.0 & $32.0 * *$ & 35.8 & 45.3 & 32.1 & $47.5 * * *$ & 44.1 & 43.4 & 39.8 & 37.5 & 43.4 & 36.2 & 37.3 & 40.8 \\
\hline (11) & 9.2 & 303 & 8.2 & 10.0 & 6.2 & 8.3 & 8.1 & 9.4 & 7.7 & 9.9 & 8.6 & 7.0 & 7.9 & $20.0 *$ & 9.6 & 8.1 & 11.3 & 7.8 \\
\hline
\end{tabular}

\begin{tabular}{|c|c|c|c|c|c|c|c|c|c|c|c|c|c|c|c|c|}
\hline \multirow[t]{2}{*}{ Question } & \multirow[t]{2}{*}{$\begin{array}{c}\text { \% agree or } \\
\text { strongly } \\
\text { agree }\end{array}$} & \multirow[t]{2}{*}{ Obs. } & \multicolumn{2}{|c|}{ CEO age } & \multicolumn{2}{|c|}{ Ownership } & \multicolumn{2}{|c|}{ Profitable } & \multicolumn{2}{|c|}{ Firm age } & \multicolumn{2}{|c|}{ Guidance } & \multicolumn{2}{|c|}{$\begin{array}{c}\text { Number of } \\
\text { analysts }\end{array}$} & \multicolumn{2}{|c|}{ CEO education } \\
\hline & & & Young & Mature & Private & Public & No & Yes & Young & Old & Little & Much & Few & Many & MBA & Other \\
\hline (1) & 92.1 & 305 & 92.2 & 92.9 & 84.1 & 92.1 & 88.0 & 93.4 & 93.1 & 90.7 & 88.5 & $94.6 *$ & 88.8 & $94.9 *$ & 94.3 & 91.1 \\
\hline (2) & 81.9 & 304 & 81.4 & 84.3 & 55.6 & $81.9 * * *$ & 78.4 & 82.9 & 77.9 & $86.0 *$ & 76.1 & $85.5 * *$ & 76.1 & $87.3 * *$ & 84.0 & 81.0 \\
\hline (3) & 72.1 & 305 & 70.3 & 78.6 & 55.6 & $72.1 * *$ & 70.7 & 72.8 & 73.3 & 72.0 & 69.0 & 74.3 & 67.8 & $76.4 *$ & 70.8 & 74.2 \\
\hline (4) & 56.2 & 306 & 55.8 & 55.7 & 51.1 & 56.2 & 57.9 & 55.7 & 50.0 & $60.7 *$ & 50.4 & 58.8 & 49.7 & $61.1 * *$ & 61.3 & 52.4 \\
\hline (5) & 50.8 & 305 & 52.6 & 44.3 & 15.9 & $50.8 * * *$ & 56.6 & 48.9 & 55.5 & 47.7 & 46.0 & 52.7 & 53.8 & 47.4 & 49.1 & 51.6 \\
\hline (6) & 48.4 & 304 & 48.5 & 47.1 & 15.6 & $48.4 * * *$ & 62.2 & $43.9 * * *$ & 55.2 & $42.7 * *$ & 44.6 & 51.3 & 45.8 & 51.6 & 47.2 & 48.1 \\
\hline (7) & 44.3 & 305 & 45.3 & 40.0 & 17.8 & $44.3 * * *$ & 48.0 & 43.0 & 44.5 & 43.3 & 42.5 & 44.4 & 48.3 & 41.4 & 43.4 & 44.7 \\
\hline (8) & 42.0 & 305 & 42.2 & 41.4 & 22.2 & $42.0 * * *$ & 37.3 & 43.4 & 44.5 & 40.0 & 36.3 & 45.5 & 33.6 & $51.0 * * *$ & 39.6 & 43.2 \\
\hline (9) & 41.3 & 305 & 40.5 & 45.7 & 46.7 & 41.3 & 40.0 & 42.1 & 43.8 & 40.7 & 41.6 & 41.2 & 41.3 & 42.0 & 40.6 & 42.6 \\
\hline (10) & 39.3 & 305 & 39.2 & 40.0 & 45.7 & 39.3 & 42.7 & 38.2 & 38.4 & 40.7 & 33.6 & 42.2 & 33.6 & $45.2 * *$ & 41.5 & 38.4 \\
\hline (11) & 9.2 & 303 & 10.4 & 5.8 & 17.8 & 9.2 & 10.8 & 7.9 & 9.7 & 8.7 & 5.4 & $11.3 *$ & 7.7 & 10.9 & 13.3 & $6.3 *$ \\
\hline
\end{tabular}


Table 12

Survey responses to the question: Limiting voluntary communication of financial information helps...

See Table 3 header for table and variable descriptions.

Panel A: Unconditional averages

\begin{tabular}{|c|c|c|c|c|c|}
\hline Question & & $\begin{array}{c}\text { \% agree or strongly } \\
\text { agree }\end{array}$ & $\begin{array}{c}\text { \% disagree or } \\
\text { strongly disagree }\end{array}$ & Average rating & $\begin{array}{c}\boldsymbol{H}_{0}: \text { Average } \\
\text { rating }=0\end{array}$ \\
\hline (1) & avoid setting a disclosure precedent that may be difficult to continue & $69.6 \%$ & $14.7 \%$ & 0.74 & $* * *$ \\
\hline (2) & avoid giving away "company secrets" or otherwise harming our competitive position & $58.8 \%$ & $24.8 \%$ & 0.49 & $* * *$ \\
\hline (3) & avoid possible lawsuits if future results don't match forward-looking disclosures & $46.4 \%$ & $25.5 \%$ & 0.26 & $* * *$ \\
\hline (4) & avoid potential follow-up questions about unimportant items & $36.7 \%$ & $30.5 \%$ & 0.04 & \\
\hline (5) & avoid attracting unwanted scrutiny by regulators & $20.3 \%$ & $56.7 \%$ & -0.52 & $* * *$ \\
\hline (6) & avoid attracting unwanted scrutiny by stockholders and bondholders & $16.8 \%$ & $54.8 \%$ & -0.56 & $* * *$ \\
\hline
\end{tabular}

Panel B: Conditional averages

\begin{tabular}{|c|c|c|c|c|c|c|c|c|c|c|c|c|c|c|c|c|c|c|}
\hline \multirow[t]{2}{*}{ Question } & \multirow{2}{*}{$\begin{array}{c}\text { \% agree or } \\
\text { strongly } \\
\text { agree }\end{array}$} & \multirow[t]{2}{*}{ Obs. } & \multicolumn{2}{|c|}{ Size } & \multicolumn{2}{|c|}{$P / E$} & \multicolumn{2}{|c|}{ Sales growth } & \multicolumn{2}{|c|}{ Debt to assets } & \multicolumn{2}{|c|}{ Credit rating } & \multicolumn{2}{|c|}{ Tech industry } & \multicolumn{2}{|c|}{ Insider } & \multicolumn{2}{|c|}{ Exchange } \\
\hline & & & Small & Large & Low & High & Low & High & Low & High & Low & High & Other & Tech & Low & High & $\begin{array}{c}\text { NASDAQ/ } \\
\text { Amex }\end{array}$ & NYSE \\
\hline (1) & 69.6 & 306 & 73.8 & 66.7 & 66.4 & 69.1 & 72.3 & 64.8 & 71.8 & 66.7 & 65.6 & 69.0 & 69.1 & 78.0 & 61.8 & $74.8 * *$ & 70.1 & 69.3 \\
\hline (2) & 58.8 & 306 & 64.4 & $52.7 * *$ & 54.0 & 63.9 & 62.2 & 58.6 & 67.2 & $52.5 * *$ & 59.1 & 61.2 & 57.8 & 68.3 & 55.9 & 61.3 & 64.6 & $54.7 *$ \\
\hline (3) & 46.4 & 306 & 48.3 & 46.0 & 46.0 & 43.3 & 46.6 & 44.5 & 49.6 & $39.7 *$ & 44.1 & 42.6 & 44.1 & $61.0 * *$ & 41.9 & 48.5 & 52.8 & $41.9 *$ \\
\hline (4) & 36.7 & 305 & 35.8 & 38.0 & 34.5 & 36.1 & 34.5 & 39.1 & 38.2 & 33.3 & 33.3 & 43.4 & 38.3 & 32.5 & 32.4 & 41.1 & 34.1 & 38.5 \\
\hline (5) & 20.3 & 305 & 20.9 & 20.7 & 15.9 & 22.7 & 21.6 & 20.3 & 20.6 & 17.0 & 17.2 & 23.3 & 19.9 & 27.5 & 15.4 & $23.3 *$ & 22.2 & 19.0 \\
\hline (6) & 16.8 & 303 & 15.8 & 18.7 & 17.7 & 17.7 & 18.9 & 17.5 & 14.6 & 18.6 & 18.5 & 19.4 & 18.5 & 10.0 & 13.4 & 19.0 & 15.3 & 17.9 \\
\hline
\end{tabular}

\begin{tabular}{|c|c|c|c|c|c|c|c|c|c|c|c|c|c|c|c|c|}
\hline \multirow[t]{2}{*}{ Question } & \multirow[t]{2}{*}{$\begin{array}{c}\text { \% agree or } \\
\text { strongly } \\
\text { agree }\end{array}$} & \multirow[t]{2}{*}{ Obs. } & \multicolumn{2}{|c|}{ CEO age } & \multicolumn{2}{|c|}{ Ownership } & \multicolumn{2}{|c|}{ Profitable } & \multicolumn{2}{|c|}{ Firm age } & \multicolumn{2}{|c|}{ Guidance } & \multicolumn{2}{|c|}{$\begin{array}{c}\text { Number of } \\
\text { analysts }\end{array}$} & \multicolumn{2}{|c|}{ CEO education } \\
\hline & & & Young & Mature & Private & Public & No & Yes & Young & Old & Little & Much & Few & Many & MBA & Other \\
\hline (1) & 69.6 & 306 & 70.4 & 68.6 & 66.7 & 69.6 & 75.0 & 68.0 & 69.9 & 68.0 & 70.8 & 68.4 & 72.0 & 66.9 & 67.0 & 70.2 \\
\hline (2) & 58.8 & 306 & 58.8 & 61.4 & 66.7 & 58.8 & 60.5 & 57.9 & 61.0 & 56.7 & 66.4 & $55.1 * *$ & 62.2 & 56.7 & 57.5 & 60.2 \\
\hline (3) & 46.4 & 306 & 47.2 & 44.3 & 40.0 & 46.4 & 51.3 & 44.7 & 52.7 & $40.0 * *$ & 47.8 & 44.4 & 48.3 & 44.6 & 44.3 & 47.1 \\
\hline (4) & 36.7 & 305 & 38.4 & 31.4 & 51.1 & $36.7 *$ & 38.7 & 36.0 & 36.3 & 36.7 & 32.7 & 39.6 & 32.2 & $41.4 *$ & 37.7 & 35.8 \\
\hline (5) & 20.3 & 305 & 19.8 & 22.9 & 31.1 & 20.3 & 22.7 & 19.7 & 23.3 & 17.3 & 23.0 & 19.3 & 17.5 & 22.3 & 23.6 & 18.9 \\
\hline (6) & 16.8 & 303 & 17.0 & 17.1 & 26.7 & 16.8 & 16.2 & 17.2 & 18.1 & 16.7 & 19.8 & 15.5 & 17.0 & 16.6 & 13.2 & 19.7 \\
\hline
\end{tabular}




\section{Table 13}

\section{Questions related to timing of disclosures}

Panel A: Survey responses to the question: Based on your company's experience, is good news or bad news released to the public faster?

$\begin{array}{ccccc} & \text { Bad news faster } & \text { No difference } & \text { Good news faster } & \text { Average rating } \\ \% \text { of respondents } & 26.6 \% & 52.9 \% & 20.5 \% & -0.12\end{array}$

Panel B: Survey responses to the question: Do the following statements describe your company's motives related to the timing of voluntary disclosures?

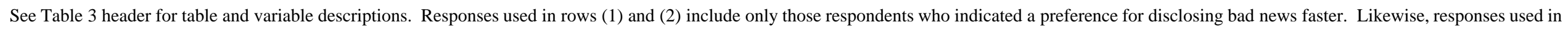
rows (3) and (4) include only those respondents who indicated a preference for disclosing good news faster.

\begin{tabular}{|c|c|c|c|c|c|}
\hline Question & & $\begin{array}{l}\text { \% agree or strongly } \\
\text { agree }\end{array}$ & $\begin{array}{l}\text { \% disagree or } \\
\text { strongly disagree }\end{array}$ & Average rating & $\begin{array}{l}\boldsymbol{H}_{0} \text { : Average } \\
\text { rating }=0\end{array}$ \\
\hline (1) & Disclosing bad news faster enhances our reputation for transparent and accurate reporting & $76.8 \%$ & $3.7 \%$ & 0.93 & $* * *$ \\
\hline (2) & Disclosing bad news faster reduces our risk of potential lawsuits & $76.8 \%$ & $8.5 \%$ & 0.91 & $* * *$ \\
\hline (3) & Good news is released faster because bad news takes longer to analyze and interpret & $66.7 \%$ & $12.7 \%$ & 0.76 & $* * *$ \\
\hline (4) & $\begin{array}{l}\text { Good news is released faster because we try to package bad news with other disclosures which can result in a } \\
\text { coordination delay }\end{array}$ & $35.5 \%$ & $37.1 \%$ & -0.05 & \\
\hline
\end{tabular}

\section{Panel B: Conditional averages}

\begin{tabular}{|c|c|c|c|c|c|c|c|c|c|c|c|c|c|c|c|c|c|c|}
\hline \multirow[t]{2}{*}{ Question } & \multirow{2}{*}{$\begin{array}{c}\% \text { agree or } \\
\text { strongly } \\
\text { agree }\end{array}$} & \multirow[t]{2}{*}{ Obs. } & \multicolumn{2}{|r|}{ Size } & \multicolumn{2}{|c|}{$P / E$} & \multicolumn{2}{|c|}{ Sales growth } & \multicolumn{2}{|c|}{ Debt to assets } & \multicolumn{2}{|c|}{ Credit rating } & \multicolumn{2}{|c|}{ Tech industry } & \multicolumn{2}{|c|}{ Insider } & \multicolumn{2}{|c|}{ Exchange } \\
\hline & & & Small & Large & Low & High & Low & High & Low & High & Low & High & Other & Tech & Low & High & $\begin{array}{c}\text { NASDAQ/ } \\
\text { Amex }\end{array}$ & NYSE \\
\hline (1) & 76.8 & 82 & 72.2 & 80.4 & 80.0 & 78.6 & 78.6 & 75.8 & 73.0 & 82.5 & 79.3 & 75.8 & 76.1 & 77.8 & 78.0 & 75.6 & 77.4 & 76.5 \\
\hline (2) & 76.8 & 82 & 75.0 & 78.3 & 88.6 & $60.7 * * *$ & 78.6 & 72.7 & 73.0 & 77.5 & 82.8 & 72.7 & 77.5 & 66.7 & 78.0 & 75.6 & 83.9 & 72.5 \\
\hline (3) & 66.7 & 63 & 68.8 & 66.7 & 68.2 & 72.7 & 61.8 & 68.4 & 66.7 & 62.1 & 60.0 & 61.5 & 66.0 & 75.0 & 68.0 & 61.8 & 57.1 & 74.3 \\
\hline (4) & 35.5 & 62 & 41.9 & 30.0 & 22.7 & 36.4 & 47.1 & $15.8 * * *$ & 38.1 & 34.5 & 13.3 & $42.3 * *$ & 36.0 & 36.4 & 40.0 & 29.4 & 37.0 & 34.3 \\
\hline
\end{tabular}

\begin{tabular}{|c|c|c|c|c|c|c|c|c|c|c|c|c|c|c|c|c|}
\hline \multirow[t]{2}{*}{ Question } & \multirow[t]{2}{*}{$\begin{array}{c}\text { \% agree or } \\
\text { strongly } \\
\text { agree }\end{array}$} & \multirow[t]{2}{*}{ Obs. } & \multicolumn{2}{|c|}{ CEO age } & \multicolumn{2}{|c|}{ Ownership } & \multicolumn{2}{|c|}{ Profitable } & \multicolumn{2}{|c|}{ Firm age } & \multicolumn{2}{|c|}{ Guidance } & \multicolumn{2}{|c|}{$\begin{array}{c}\text { Number of } \\
\text { analysts }\end{array}$} & \multicolumn{2}{|c|}{ CEO education } \\
\hline & & & Young & Mature & Private & Public & No & Yes & Young & Old & Little & Much & Few & Many & MBA & Other \\
\hline (1) & 76.8 & 82 & 77.8 & 72.2 & 71.4 & 76.8 & 70.6 & 78.5 & 75.0 & 79.1 & 75.0 & 78.3 & 70.6 & 80.9 & 84.0 & 74.1 \\
\hline (2) & 76.8 & 82 & 74.6 & 83.3 & 42.9 & $76.8 *$ & 82.4 & 75.4 & 77.8 & 76.7 & 72.2 & 80.4 & 82.4 & 72.3 & 56.0 & $85.2 * * *$ \\
\hline (3) & 66.7 & 63 & 65.3 & 71.4 & 55.6 & 66.7 & 54.5 & 71.1 & 69.0 & 58.6 & 60.9 & 69.4 & 63.3 & 69.0 & 76.2 & 61.9 \\
\hline (4) & 35.5 & 62 & 39.6 & 21.4 & 38.9 & 35.5 & 42.9 & 28.9 & 41.4 & 27.6 & 39.1 & 33.3 & 33.3 & 37.9 & 23.8 & 41.5 \\
\hline
\end{tabular}




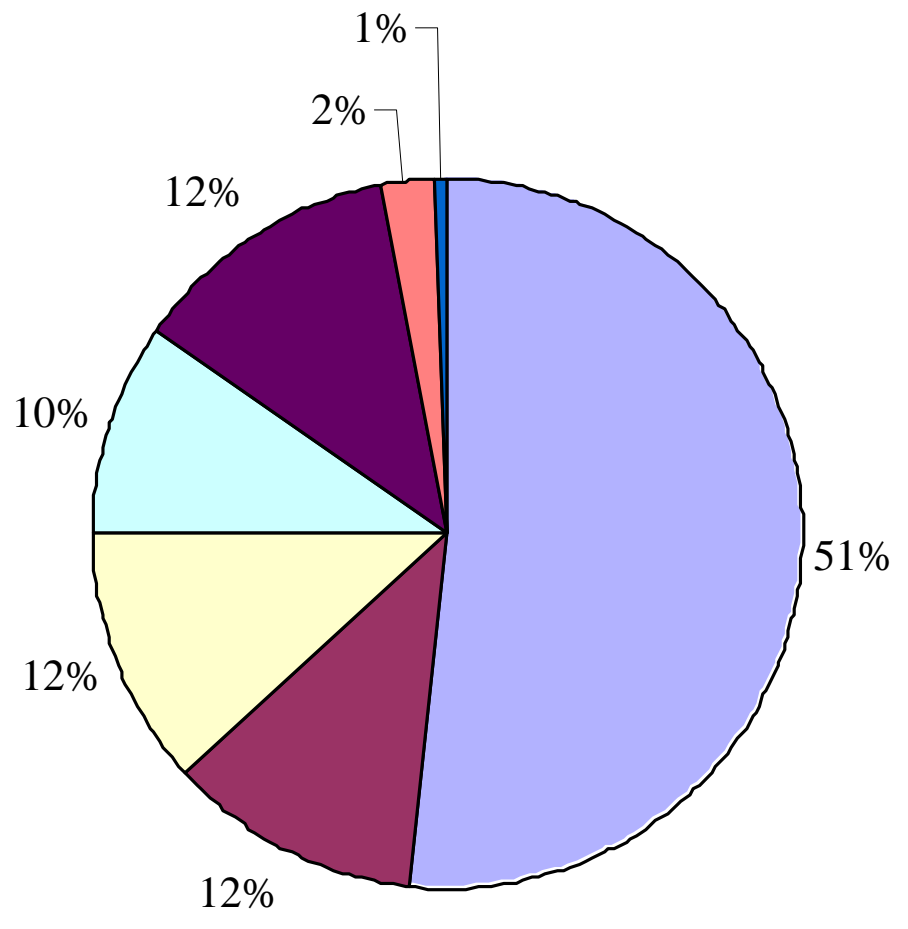

$\square$ Earnings
$\square$ Revenues
$\square$ Cash flows from
operations
$\square$ Free cash flows
$\square$ Pro forma earnings
$\square$ Other
$\square$ EVA

Fig. 1. Responses to the question: "Rank the three most important measures report to outsiders” based on a survey of 401 financial executives. 


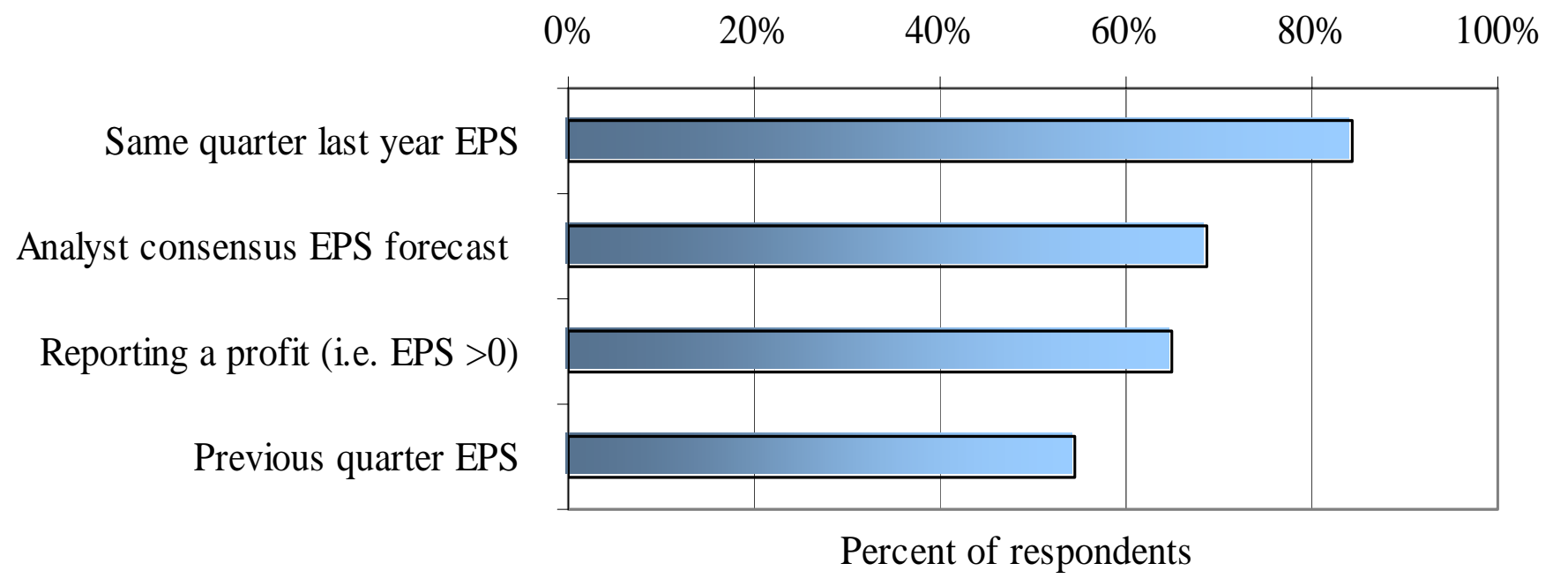

Fig. 2. Responses to the question: "How important are following earnings benchmarks?" based on a survey of 401 financial executives. 
build credibility with capital market maintain or increase our stock price external reputation of management convey future growth prospects to investors reduce stock price volatility assures stakeholders business is stable employees achieve bonuses achieve desired credit rating avoid violating debt-covenants

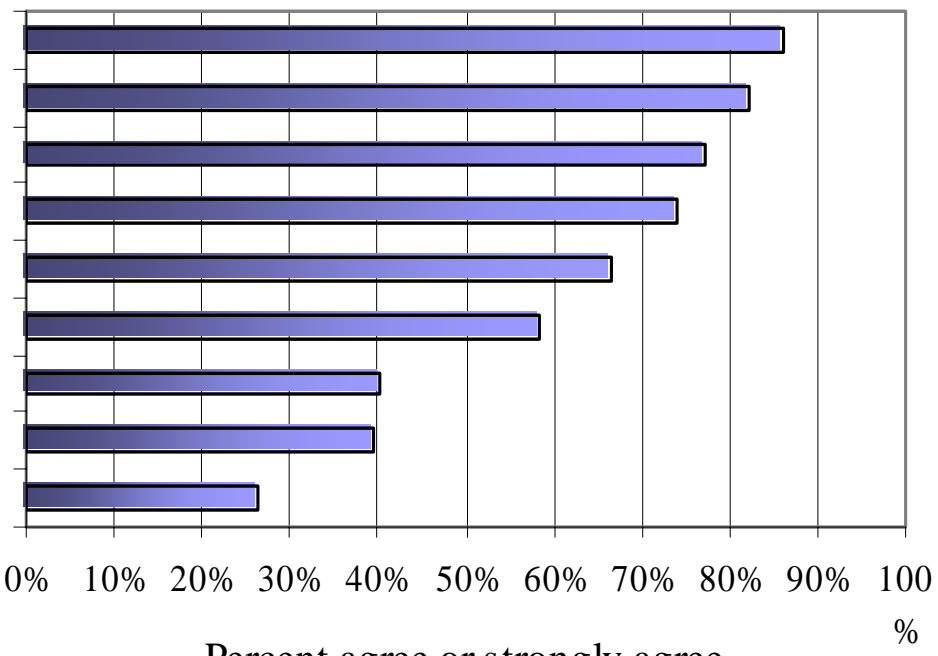

Percent agree or strongly agree

Fig. 3. Responses to the statement: "Meeting earnings benchmarks helps ..." based on a survey of 401 financial executives. 
creates uncertainty about our future prospects outsiders think there are previously unknown problems have to spend time explaining why we missed increases scrutiny of all aspects of earnings releases outsiders might think firm lacks flexibility increases the possibility of lawsuits

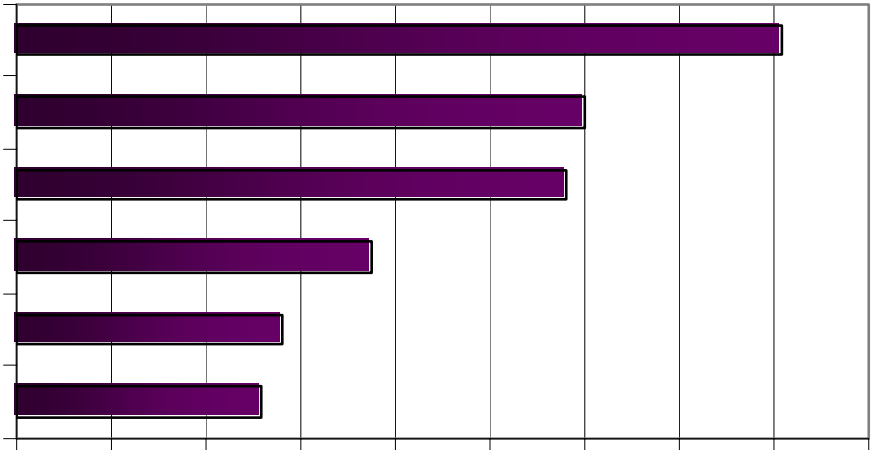

0\% $10 \% \quad 20 \% \quad 30 \% \quad 40 \% \quad 50 \% \quad 60 \% \quad 70 \% \quad 80 \% 90 \%$

Percent agree or strongly agree

Fig. 4. Responses to the statement: "Failing to meet benchmarks..." based on a survey of 401 financial executives. 


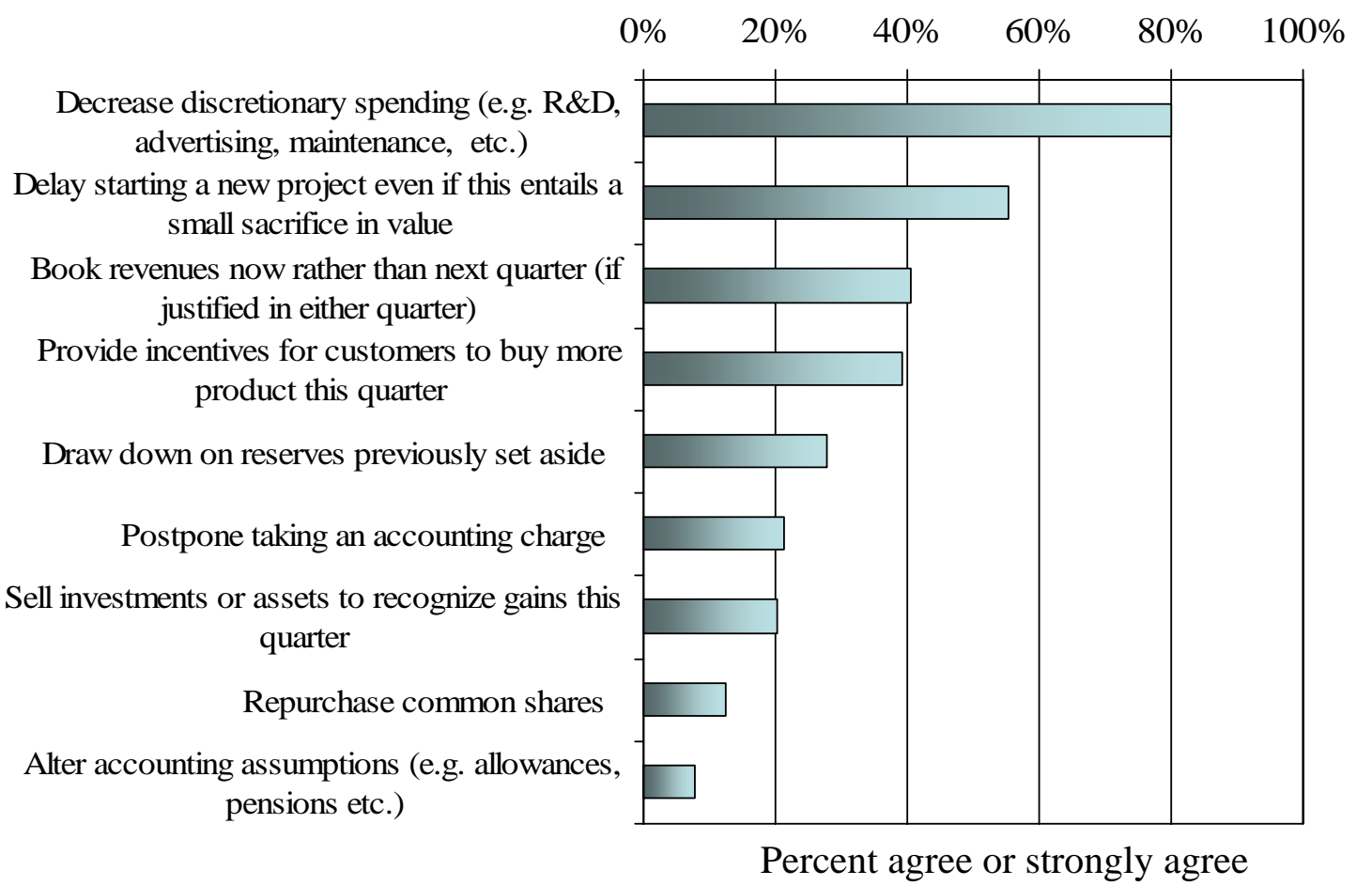

Fig. 5. Responses to the question: "Near the end of the quarter, it looks like your company might come in below the desired earnings target. Within what is permitted by GAAP, which of the following choices might your company make?” based on a survey of 401 financial executives. 


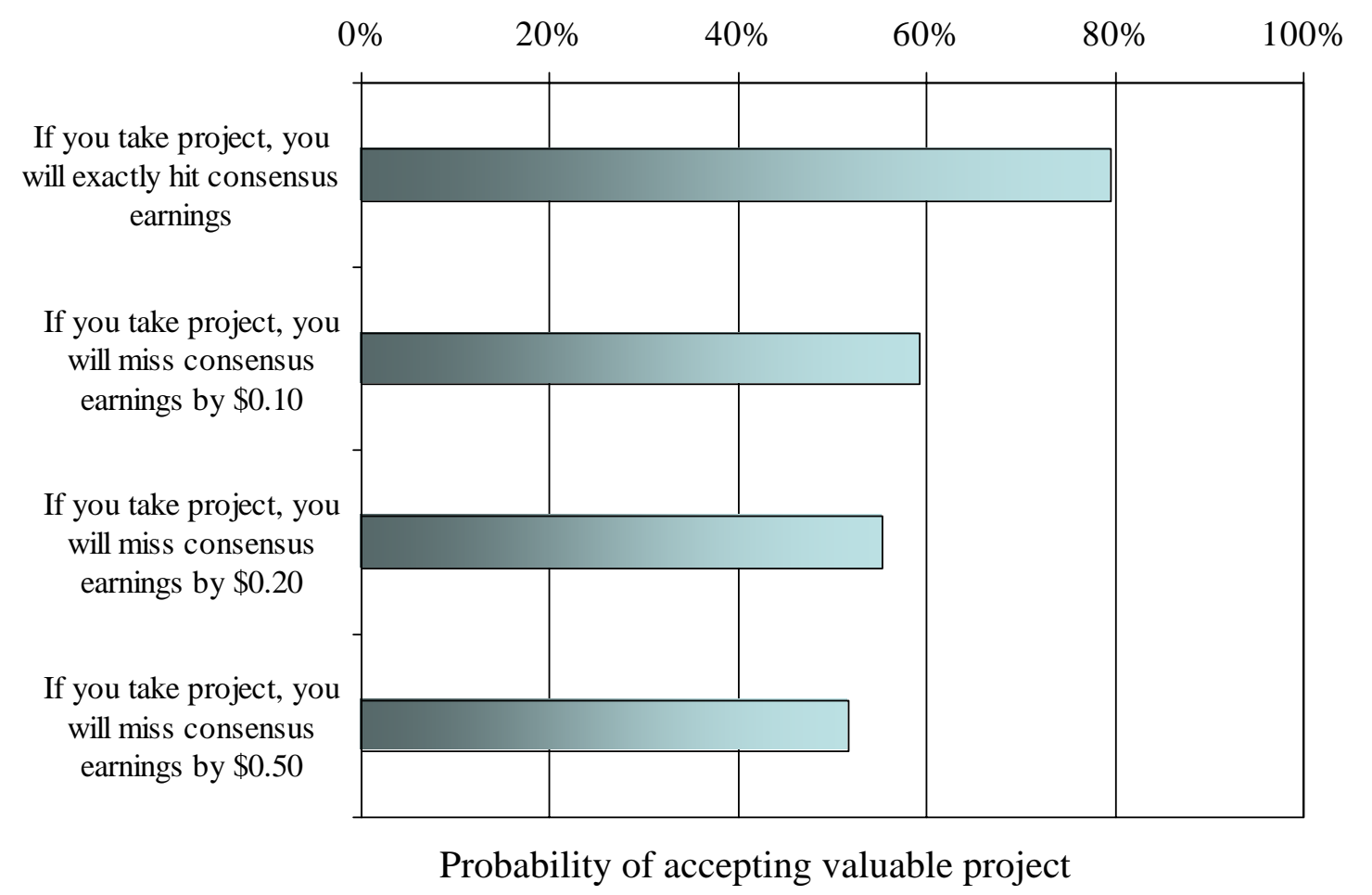

Fig. 6. Responses to the statement and question: "Your company's cost of capital is $12 \%$. Near the end of the quarter, a new opportunity arises that offers a $16 \%$ internal rate of return and the same risk as the firm. What is the probability that your company will pursue this project in each of the following scenarios?” based on a survey of 401 financial executives. 


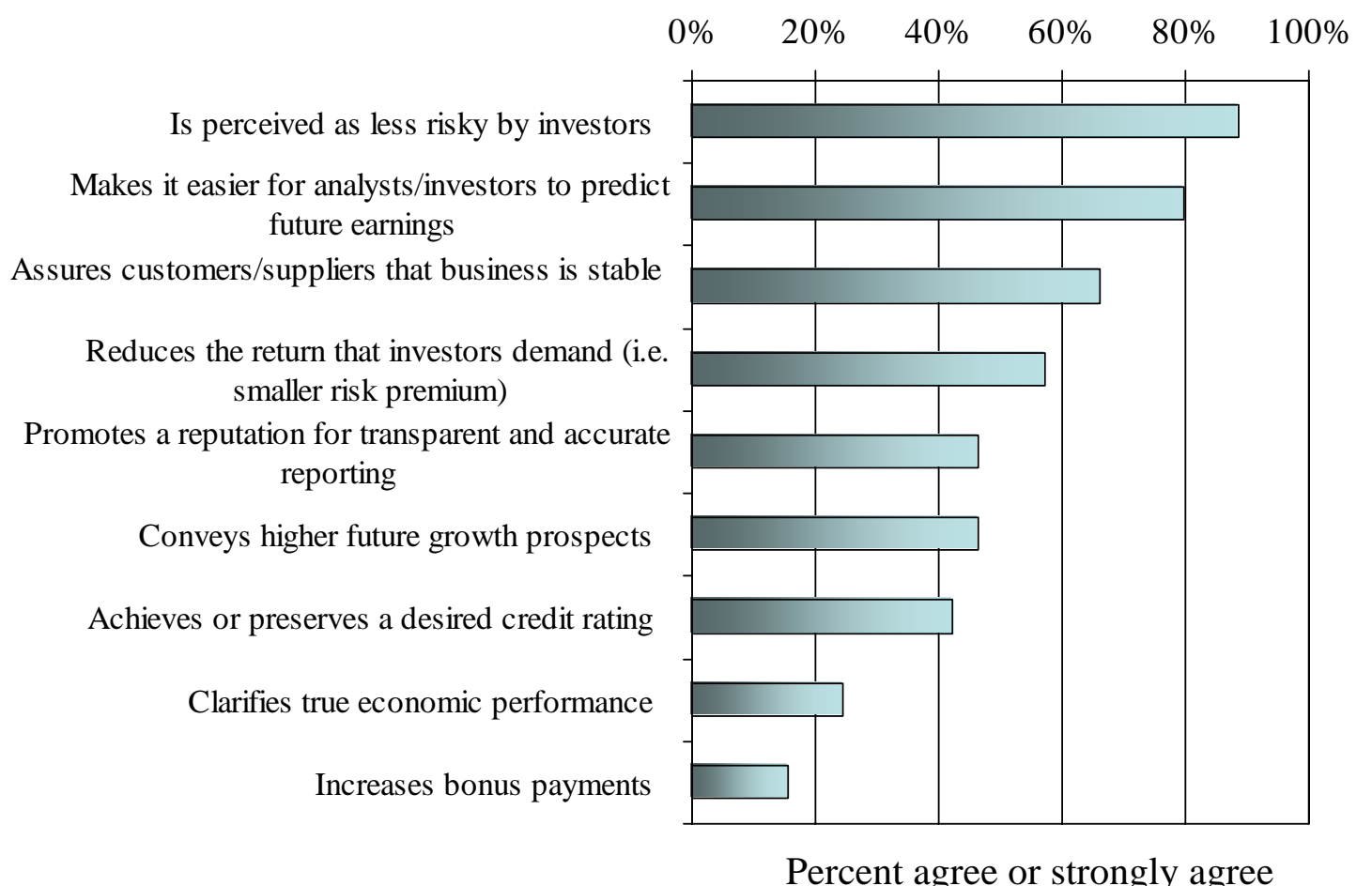

Fig. 7. Responses to the question: "Do the following factors contribute to your company preferring a smooth earnings path?” based on a survey of 401 financial executives. 


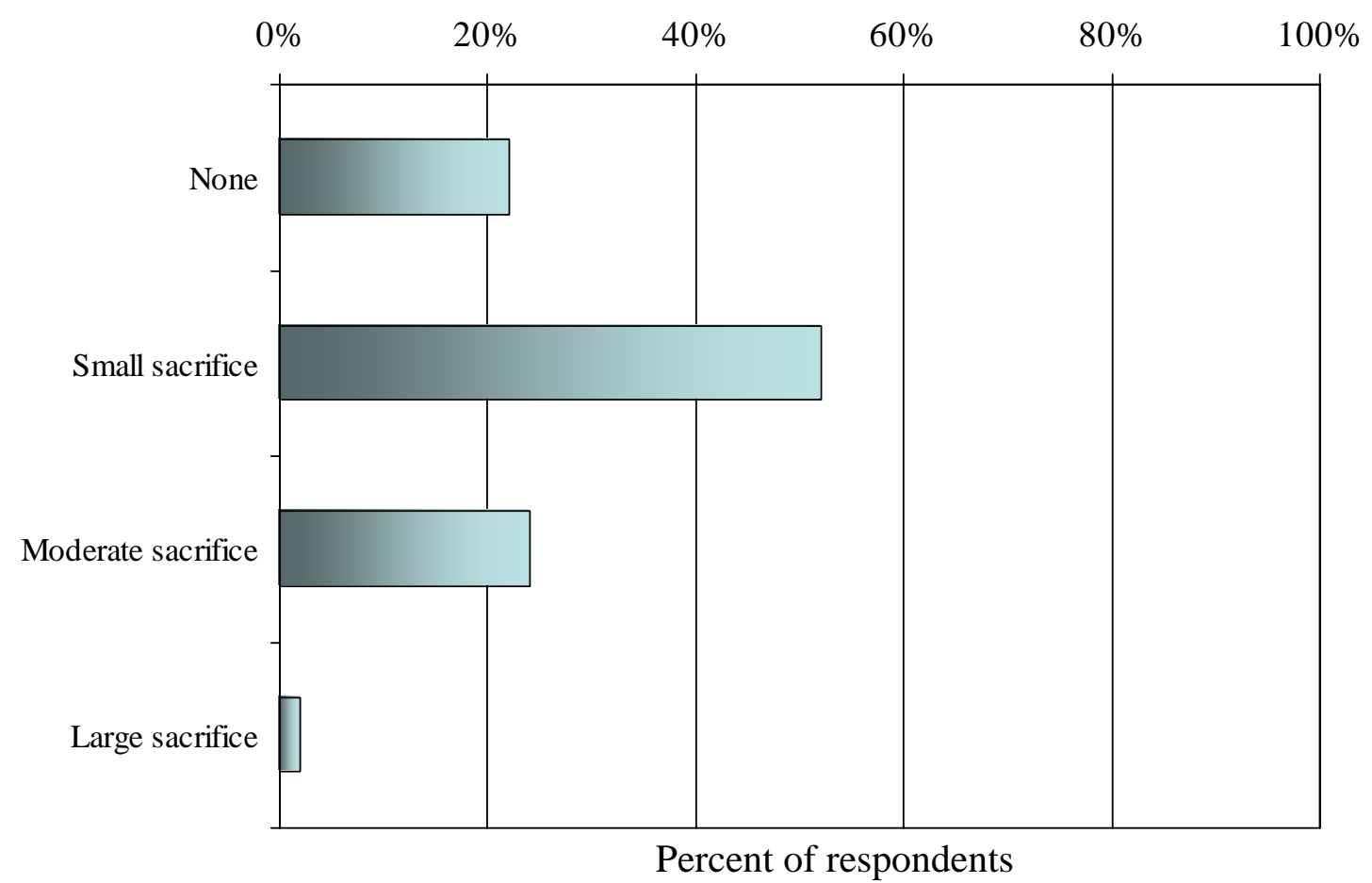

Fig. 8. Responses to the question: "How large a sacrifice in value would your firm make to avoid a bumpy earnings path?” based on a survey of 401 financial executives. 


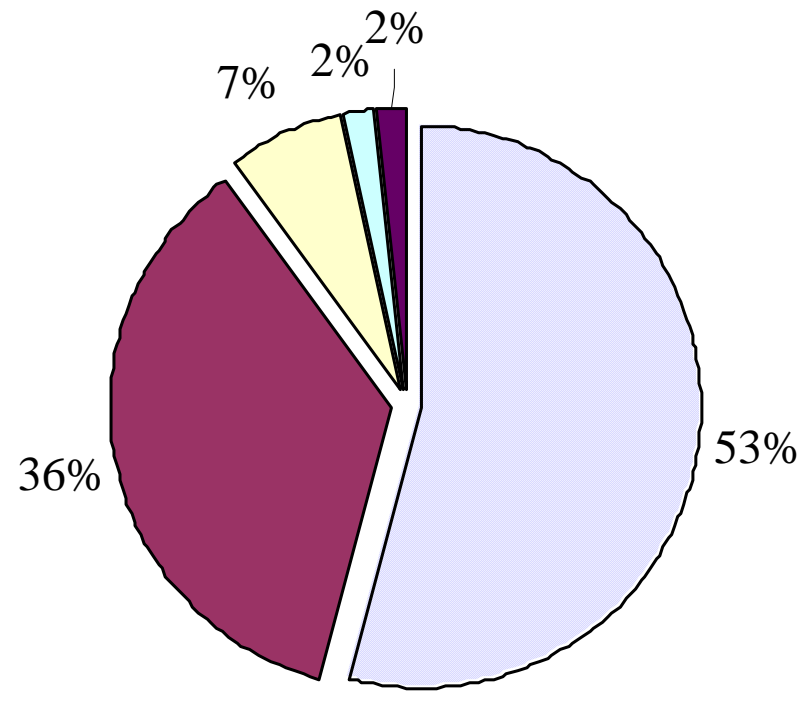

$\square$ Institutions

$\square$ Analysts

$\square$ Individuals

$\square$ Rating Agencies

$\square$ Hedge Funds

Fig. 9. Responses to the statement: "Rank the two most important groups in terms of setting the stock price for your company" based on a survey of 401 financial executives. 


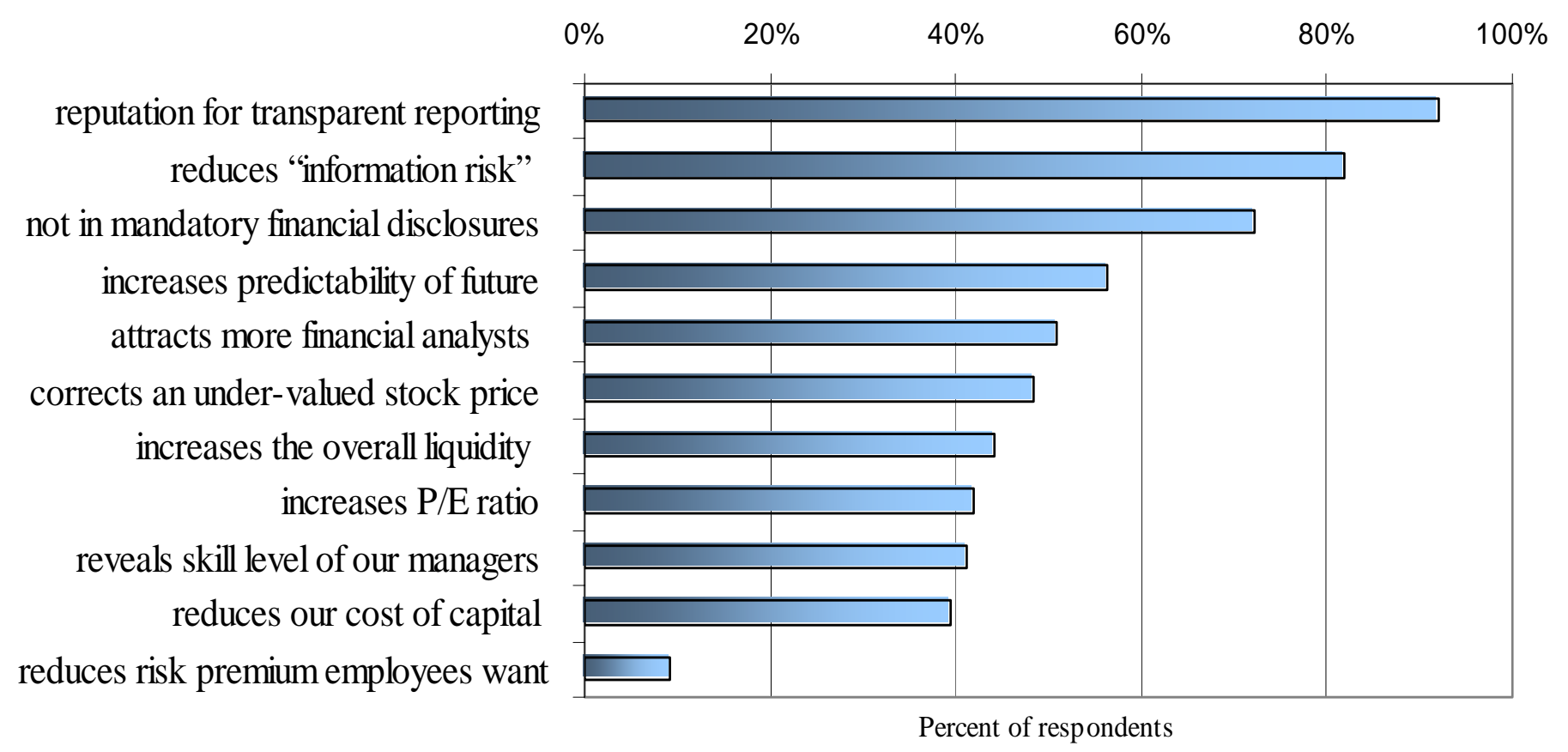

Fig. 10. Responses to the question: "Why make voluntary disclosures?” based on a survey of 401 financial executives. 


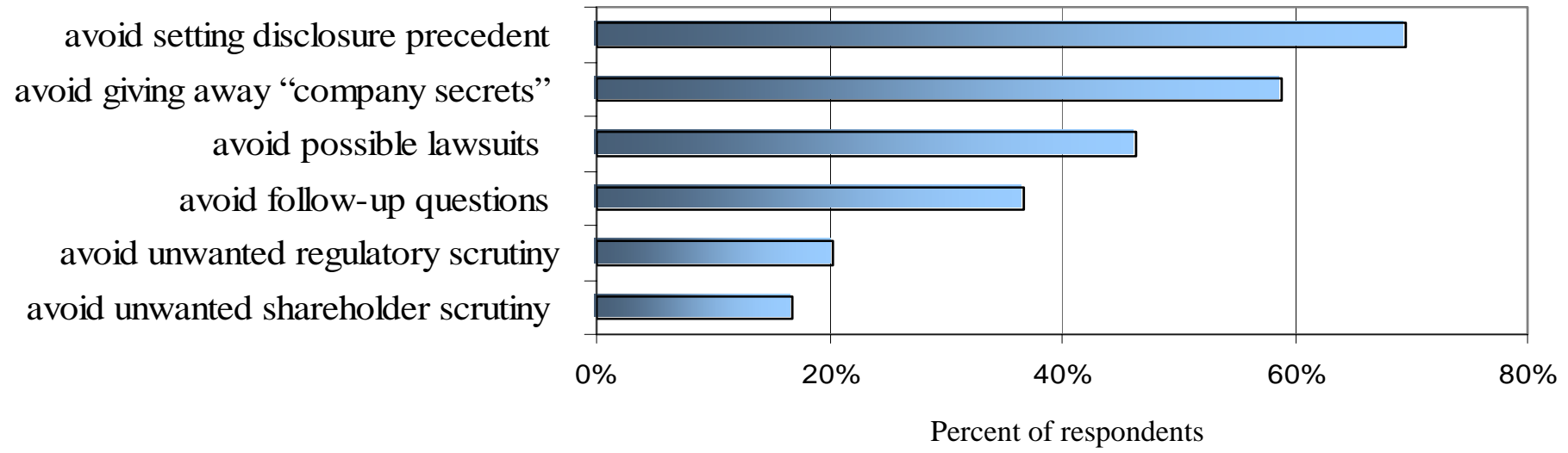

Fig. 11. Responses to the question: "Limiting voluntary communication of financial information helps to ..." based on a survey of 401 financial executives. 


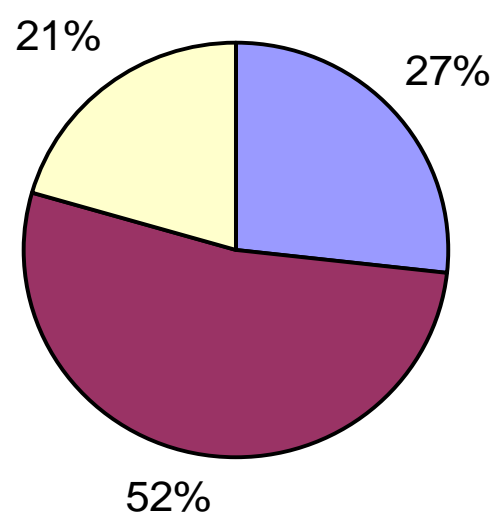

$\square$ Bad news faster

$\square$ No difference

$\square$ Good news faster

Fig. 12. Responses to the question: "Is good news released faster than bad news?” based on a survey of 401 financial executives. 